\title{
Unidades de conservação na região semiárida do Brasil
}

\section{Ronilson José da Paz ${ }^{1}$, Marilia Carolina Pereira da $\mathrm{Paz}^{2}$, João Alberto Lins Filho ${ }^{3}$ e Reinaldo Farias Paiva de Lucena $^{3}$}

${ }^{1}$ Universidade Federal da Paraíba. Centro de Ciências Exatas e da Natureza. Programa de Pós-Graduação em Desenvolvimento e Meio Ambiente. Campus Universitário. João Pessoa-PB, Brasil (CEP 58051-900). E-mail: ronilsonpaz4@gmail.com.

${ }^{2}$ Universidade Federal da Paraíba. Centro de Ciências Aplicadas e Educação. Programa de Pós-Graduação em Ecologia e Monitoramento Ambiental. Campus IV. Rua da Mangueira, S/№. Centro. Rio Tinto-PB, Brasil (CEP 58297-000).

${ }^{3}$ Universidade Federal da Paraíba. Centro de Ciências Exatas e da Natureza. Departamento de Sistemática e Ecologia. Laboratório de Etnobiologia e Ciências Ambientais. Cidade Universitária, S/№. João Pessoa-PB, Brasil (CEP 58051-900).

Resumo. As unidades de conservação são espaços territoriais legalmente protegidos por ato governamental consideradas como a principal ferramenta para a conservação da biodiversidade in situ. Com o advento da Lei no 9.985/2000, que criou o Sistema Nacional de Unidades de Conservação (SNUC), foi inaugurada a política de gestão territorial, com o intuito de melhor conservar a biodiversidade, principalmente pela proteção dos biomas brasileiros mais susceptíveis à degradação ambiental, como é a Caatinga, característica da região semiárida. Portanto, este trabalho tem como objetivo traçar um panorama atual das unidades de conservação criadas na Região do Semiárido do Brasil, através de pesquisa bibliográfica e da legislação vigente. Ao final da pesquisa, foi observado que foram criadas 252 unidades de conservação em todos os estados que abrangem a Região Semiária do Brasil, das quais 72 são de proteção integral e 180 de uso sustentável, sendo as reservas particulares do patrimônio natural (RPPN) foram as mais criadas (119), no entanto protegem apenas $0,06 \%$ do semiárido. Tendo em vista a fragilidade do Bioma Caatinga, há a necessidade premente de aumentar o alcance das políticas públicas para proteger seus ecossistemas.

Palavras-chave: Proteção da Natureza; Unidades de conservação; Semiárido; Caatinga.

Abstract. Conservation units in the semiarid region of Brazil. Conservation units are territorial spaces legally protected by a government act considered as the main tool for the conservation
Recebido

$29 / 09 / 2020$

Aceito

$30 / 10 / 2020$

Disponível on line

$02 / 11 / 2020$

Publicado

$31 / 12 / 2020$

Acesso aberto

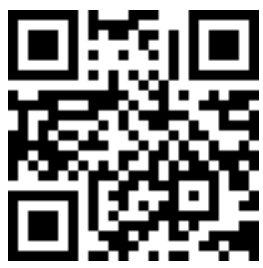

ORCID

(D) 0000-0002-4990-4495 Ronilson José da Paz

ISSN 2359-1412/RBGAS-2020-0148/2020/7/17/18/1283

Rev. Bras. Gest. Amb. Sustent.

http://revista.ecogestaobrasil.net 
of biodiversity in situ. With the advent of Law 9,985/2000, which created the National System of Conservation Units (SNUC), the territorial management policy was inaugurated, with the aim of better conserving biodiversity, mainly by protecting the Brazilian biomes most susceptible to degradation environmental, as is the Caatinga, characteristic of the semiarid region. Therefore, this work aims to outline a current panorama of the conservation units created in the Semi-Arid Region of Brazil, through bibliographic research and current legislation. At the end of the research, it was observed that 252 conservation units were created in all states that comprise the Seminary Region of Brazil, of which 72 are fully protected and 180 for sustainable use, with private reserves of natural heritage (RPPN) being the most created (119), however, they protect only $0.06 \%$ of the semiarid. In view of the fragility of the Caatinga Biome, there is an urgent need to increase the reach of public policies to protect their ecosystems.

Keywords: Nature protection; Conservation units; Semiarid; Caatinga.

\section{Introdução}

A conciliação da exploração dos recursos ambientais com o desenvolvimento econômico sempre foi um dos principais desafios para a humanidade. 0 padrão de consumo capitalista da espécie humana, baseado na subjugação e superexploração da Natureza, no consumo desenfreado e na obsolescência programada, atualmente encontra-se diante de uma crise socioambiental, que coloca a Natureza a serviço da humanidade, e não o oposto, devendo esta visão antropocêntrica ser abandonada, de modo que os recursos ambientais possam ser poupados e restabelecidos.

Tentando chamar a atenção do poder público e dos setores econômico e produtivo com relação à insustentabilidade do padrão do consumo humano adotado na sociedade contemporânea, foram realizadas reuniões em Estocolmo (1972) e no Rio de Janeiro (1992), quando nasceram e foram disseminadas as primeiras sementes do desenvolvimento sustentável, incluindo as dimensões, social, econômica e ambiental na agenda política internacional.

Estas reuniões sempre foram palco para as discussões acadêmicas acerca da sustentabilidade, quando surgiram publicações alarmistas sobre o tema, como a "primavera silenciosa" de 1963 (Carson, 2010), que alertava para o uso exagerado dos agrotóxicos; o relatório para o Clube de Roma, "os limites do crescimento", que recomendava a desaceleração do crescimento industrial nos países desenvolvidos e a diminuição da taxa de natalidade nos países subdesenvolvidos (Meadows et al., 1972); o artigo de Naess (1973), que lançava as bases teóricas da Ecologia Profunda, direcionada aos estudos ecológicos dos problemas estruturais existentes nas sociedades em todo o mundo (Nascimento, 2012); o relatório "nosso futuro comum", que clamava os governos para agir, inclusive sugerindo uma agenda (Brundtland, 1987), entre outros.

No Brasil, o debate relacionados às questões ambientais é institucionalizado, com a criação, pelo Decreto no 70.030/1973 (Brasil, 1973), da Secretaria Especial do Meio Ambiente (SEMA), vinculada ao Ministério do Interior, que tinha as seguintes atribuições:

Art. 4º À SEMA compete: 
a) acompanhar as transformações do ambiente através de técnicas de aferição direta e sensoreamento remoto, identificando as ocorrências adversas, e atuando no sentido de sua correção;

b) assessorar órgão e entidades incumbidas da conservação do meio ambiente, tendo em vista o uso racional dos recursos naturais;

c) promover a elaboração e o estabelecimento de normas e padrões relativos à preservação do meio-ambiente, em especial dos recursos hídricos, que assegurem o bem-estar das populações e o seu desenvolvimento econômico e social;

d) realizar diretamente ou colaborar com os órgãos especializados no controle e fiscalização das normas e padrões estabelecidos;

e) promover, em todos os níveis, a formação e treinamento de técnicos e especialistas em assuntos relativos à preservação do meio ambiente;

f) atuar junto aos agentes financeiros para a concessão de financiamentos a entidades públicas e privadas com vista à recuperação de recursos naturais afetados por processos predatórios ou poluidores;

g) cooperar com os órgãos especializados na preservação de espécies animais e vegetais ameaçadas de extinção, e na manutenção de estoques de material genético;

h) manter atualizada a Relação de Agentes Poluidores e Substâncias Nocivas, no que se refere aos interesses do País;

i) promover, intensamente, através de programas em escala nacional, o esclarecimento e a educação do povo brasileiro para o uso adequado dos recursos naturais, tendo em vista a conservação do meio ambiente. (BRASIL, 1973).

Coube então à Lei no 6.938/1981, ao instituir a Política Nacional de Meio Ambiente (PNMA), criar o Conselho Nacional de Meio Ambiente (CONAMA) (Ferreira e Salles, 2016) e introduzir os instrumentos de gestão ambiental para a exploração dos recursos naturais, por meio do licenciamento ambiental (Brasil, 1981).

Com a criação do Ministério do Desenvolvimento Urbano e Meio Ambiente, através do Decreto no 91.145/1985 (Brasil, 1985), a Secretaria Especial do Meio Ambiente (SEMA) foi para lá transferida.

À nova Constituição Federal de 1988 (Brasil, 1988), coube reservar um capítulo exclusivo para o meio ambiente, consagrando-o como um "bem de uso comum do povo e essencial à sadia qualidade de vida" (art. 225, caput), como também institucionalizar a gestão ambiental em todas as esferas de governo, absorvendo a filosofia da conservação ambiental instituída pela Política Nacional de Meio Ambiente (Lei no 6.938/1981) (Brasil, 1981).

A Convenção sobre Diversidade Biológica (CDB), aprovada pelo Decreto Legislativo no 2/1994 (Brasil, 1994) e promulgada pelo Decreto no 2.519/1998, da qual o Brasil e mais de 160 países são signatários, surgiu durante a Conferência das Nações Unidas sobre Meio Ambiente e Desenvolvimento (CNUMAD), realizada no Rio de Janeiro, mundialmente conhecida como a ECO-92 ou RIO-92, possui três objetivos, que justificam a criação de áreas legalmente protegidas:

\section{Artigo 1}

Objetivos

Os objetivos desta Convenção, a serem cumpridos de acordo com as disposições pertinentes, são a conservação da diversidade biológica, a utilização sustentável de seus componentes e a repartição justa e equitativa dos benefícios derivados da utilização dos recursos genéticos, mediantes, inclusive, o acesso adequado aos recursos genéticos e a transferência adequada de tecnologias pertinentes, levando em conta todos os direitos sobre tais recursos e tecnologias, e mediante financiamento adequado (Brasil, 1994). 
O Brasil é um dos países do mundo que detém a maior biodiversidade, mas este status pode estar sendo comprometido, devido às perdas pelo avanço do desmatamento, pelo avançado processo de urbanização e agropecuária que provocam a conversão das paisagens naturais em florestas secundárias. Apesar das ameaças à diversidade biológica serem visíveis, o Brasil também se tornou um expoente mundial em conservação da biodiversidade (Mittermeier et al., 2005), principalmente pelo arcabouço legal construído nesses últimos 40 anos.

A criação de espaços territoriais legalmente instituídos é amplamente considerada como o principal instrumento para a conservação in situ da biodiversidade (Lino et al., 1999; Rodrigues et al., 2004a, 2004b; Loucks et al., 2008; Jenkinsa e Joppa, 2009; Braga e Maciel, 2011), estando essas áreas em expansão progressiva no âmbito global (Jenkinsa e Joppa, 2009). No Brasil, a institucionalização destas áreas, seguiu o modelo internacional adotado na criação do Parque Nacional de Yellowstone, em 1872, que inaugurou um modelo de gestão inovador reconhecido e amplamente copiado internacionalmente, sendo adotado na criação do Parque Nacional de Itatiaia, nos Estados do Rio de Janeiro e Minas Gerais, pelo Decreto no 1.713/1937 (Brasil, 1937).

Com a criação do Sistema Nacional de Unidades de Conservação da Natureza (SNUC), pela Lei no 9.985/2000 (Brasil, 2000), inaugurou-se a política de gestão territorial, com o intuito de conservação da biodiversidade, principalmente pela proteção dos biomas brasileiros, quando foi instituindo o conceito de unidade de conservação:

Art. $2^{\circ}$ Para os fins previstos nesta Lei, entende-se por:

I - unidade de conservação: espaço territorial e seus recursos ambientais, incluindo as águas jurisdicionais, com características naturais relevantes, legalmente instituído pelo Poder Público, com objetivos de conservação e limites definidos, sob regime especial de administração, ao qual se aplicam garantias adequadas de proteção; (Brasil, 2000).

A política de criação de áreas protegidas através da institucionalização de unidades de conservação ainda provoca grandes conflitos, isto porque depois que são criadas, as unidades de conservação precisam resolver entraves à sua gestão provocados principalmente por conflitos fundiários e pela gestão de seus recursos naturais, como o citado por Oliveira et al. (2017).

As condições climáticas e pedológicas da Região Semiárida do Brasil favorece a predominância do Bioma Caatinga, ou das Caatingas (Ab'Saber, 1974; Andrade-Lima, 1981; Bernardes, 1999), considerando a sua heterogeneidade, que é caracterizada por uma vegetação relativamente baixa, em comparação a outros biomas, folhas pequenas e caules com espinhos, de fisionomia e florística bem variadas e com grande quantidade de xerófilas (Andrade-Lima, 1981; Bernardes, 1999).

Considerando o manejo inadequado e insustentável dos solos e demais recursos naturais, bem como por apresentar uma pequena área protegida em unidades de conservação a Caatinga é um dos biomas mais ameaçados no Brasil (Franca-Rocha et al., 2012; Falcão e Tavares, 2020). Isto porque, historicamente, a Região Semiárida no Brasil sempre foi palco de profundas transformações antrópicas no solo, na vegetação e na fauna, e sua conservação nem sempre foi tratada com a prioridade necessária.

Embora do ponto de vista legal a Caatinga seja o bioma mais negligenciado do Brasil, este antigo uso dos recursos naturais pela população lá residente atraiu a atenção do legislador com a criação de unidades de conservação, de modo a impor limites e evitar conflitos no seu uso (Brasileiro et al., 2018) e para que o bioma possa ser compartilhado pelas mais variadas populações. 
Assim, este trabalho tem o objetivo de traçar um panorama das unidades de conservação criadas na Região do Semiárido do Brasil.

\section{Fundamentação teórica}

\section{Unidades de conservação}

A criação pelo Poder Público de espaços geograficamente definidos com o objetivo de conservar a biodiversidade em locais com atributos naturais excepcionais é um instrumento relativamente antigo na história da Índia, da África do Sul (o povo Venda), da China, de Veneza, da Bretanha, da Rússia e da Inglaterra (Silva e Cunha, 2010). Embora o Parque Nacional de Yosemite tenha sido criado nos Estados Unidos em 1864 (Paz et al., 2006), foi o modelo adotado na criação do Parque Nacional de Yellowstone, nos Estados Unidos, em 1872, que contribuiu para a disseminação deste instrumento de conservação da biodiversidade in situ (Braga e Maciel, 2011). Inspirada neste modelo adotado no Parque Nacional de Yellowstone, a criação de parques e outros tipos de áreas protegidas foram impulsionadas no Canadá, em 1985, na Nova Zelândia, em 1894, na Austrália, na África do Sul e no México, em 1898, na Argentina, em 1903, no Chile, em 1926, no Equador, em 1934, e na Venezuela, em 1937 (Braga e Maciel, 2011).

No Brasil, como contam Paz et al. (2006), a criação destas áreas protegidas remontam ainda do final do século XIX, com criação, em 1886, no âmbito estadual, da primeira unidade de conservação, o Parque Estadual da Cidade, no Estado de São Paulo.

$\mathrm{Na}$ esfera federal, a primeira unidade de conservação foi criada na Amazônia, a Reserva Florestal no Território do Acre, com o objetivo de proteger e assegurar a navegação fluvial e, consequentemente, de obstar que o regime hidrográfico respectivo sofra modificações que alterassem a navegabilidade do Rio Acre e do Rio Purus (Brasil, 1911; Paz et al., 2006; Vital, 2018).

Além de criar a primeira unidade de conservação federal no Brasil, e a primeira a ficar no papel, sem a efetiva implementação, este Decreto no 8.843/1911 é o marco legal para o reconhecimento do Governo Brasileiro das consequências das mudanças climáticas, uma vez que declara textualmente que a "devastação desordenada das matas está produzindo em todo o país efeitos sensíveis e desastrosos, salientando-se entre eles alterações na constituição climática de várias zonas e no regime das águas pluviais e das correntes que delas dependem" (Brasil, 1911).

A institucionalização de áreas protegidas no Brasil seguiu com o debate internacional relacionado à temática, culminando com a sanção do Código Florestal de 1934, anexo ao Decreto no 23.739/1934 (Brasil, 1934), que classificou as florestas protetoras como sendo aquelas que, dentre outras funções, asilam espécies raras da fauna silvestre, e as florestas remanescentes, as que formam os parques nacionais, estaduais ou municipais, conferindo grau de conservação a estas áreas.

Após 27 anos de espera, em relação à criação da primeira unidade de conservação federal, em 1937 foi criado o Parque Nacional de Itatiaia, localizado na Serra da Mantiqueira, abrangendo os Municípios de Itatiaia e Resende, no Estado do Rio de Janeiro, e Bocaina de Minas e Itamonte no Estado de Minas Gerais. Mas esta espera poderia ter sido menor se a proposta para a criação do Parque Nacional da Ilha do Bananal e do Parque Nacional de Sete Quedas, do Engenheiro André Rebouças, em 1876, fosse encampada pelo Poder Público Federal (Paz et al., 2006). O Parque Nacional do Araguaia, no Estado de Goiás, atualmente no Estado de Tocantins, que abrange a Ilha do Bananal, foi criado em 1959 (Brasil, 1959), e o Parque Nacional de Sete Quedas, na Região de Guaíra ou Sete Quedas, no Estado do Paraná, foi criado em 1961 (Brasil, 1961) e extinto em 1981 (Brasil, 1981) para ser inundado pela Usina Hidrelétrica de Itaipu.

Rev. Bras. Gest. Amb. Sustent., 2020, vol. 7, n. 17, p. 1283-1334. 
Posteriormente, embora revogado pela Lei no 9.985/2000 (Brasil, 2000), o Novo Código Florestal de 1965 (Lei no 4771/1965), além de instituir as áreas de preservação permanente e as áreas de reserva legal, determinava que o Poder Público criaria parques nacionais, estaduais e municipais, bem como reservas biológicas, com o intuito de "resguardar atributos da Natureza, conciliando a proteção integral da flora, da fauna e das belezas naturais, com a utilização para objetivos educacionais, recreativos e científicos", além de Florestas Nacionais, Estaduais e Municipais, com fins econômicos, técnicos ou sociais:

Art. 5o 0 Poder Público criará:

a) Parques Nacionais, Estaduais e Municipais e Reservas Biológicas, com a finalidade de resguardar atributos excepcionais da natureza, conciliando a proteção integral da flora, da fauna e das belezas naturais com a utilização para objetivos educacionais, recreativos e científicos;

b) Florestas Nacionais, Estaduais e Municipais, com fins econômicos, técnicos ou sociais, inclusive reservando áreas ainda não florestadas e destinadas a atingir aquele fim.

Parágrafo único. Fica proibida qualquer forma de exploração dos recursos naturais nos Parques Nacionais, Estaduais e Municipais. (Brasil, 1965).

Nesta mesma linha de pensamento, a Lei no 5.197/1967 (Brasil, 1967), de proteção à fauna, estabelece que o Poder Público criará Reservas Biológicas Nacionais, Estaduais e Municipais, com o intuito de conservação da fauna silvestre:

Art. 5o 0 Poder Público criará:

a) Reservas Biológicas Nacionais, Estaduais e Municipais, onde as atividades de utilização, perseguição, caça, apanha, ou introdução de espécimes da fauna e flora silvestre e domésticas, bem como modificações do meio ambiente a qualquer título, são proibidas, ressalvadas as atividades científicas devidamente autorizadas pela autoridade competente. (Brasil, 1967).

Foi a Lei no 6.902/1981 (Brasil, 1981) que estabeleceu os critérios para a criação e os conceitos de Estações Ecológicas e Áreas de Proteção Ambiental. Entretanto, foi a Lei no 6.938/1981 que estabeleceu "a criação de reservas e estações ecológicas, áreas de proteção ambiental e as de relevante interesse ecológico, pelo Poder Público Federal, Estadual e Municipal", como instrumento da Política Nacional do Meio Ambiente (Brasil, 1981; art. 9․, inciso VI), sendo dada nova redação pela Lei no 7.804/1989, para adequá-lo aos novos ditames da Constituição Federal de 1988:

Art 9ํㅗ̃o instrumentos da Política Nacional do Meio Ambiente: (Brasil, 1981):

$[\ldots]$

VI - a criação de espaços territoriais especialmente protegidos pelo Poder Público federal, estadual e municipal, tais como áreas de proteção ambiental, de relevante interesse ecológico e reservas extrativistas; (Brasil, 1989, art. 1, inciso VI).

É que, uma das principais inovações da Constituição Federal de 1988 foi reservar um capítulo exclusivo para tratar do meio ambiente, que consagra que:

Art. 225. Todos têm direito ao meio ambiente ecologicamente equilibrado, bem de uso comum do povo e essencial à sadia qualidade de vida, impondo-se ao Poder Público e à coletividade o dever de defendê-lo e preservá-lo para as presentes e futuras gerações. (Brasil, 1988). 
Para garantir e assegurar a efetividade do direito ao meio ambiente ecologicamente equilibrado consagrado pelo caput do art. 225, dentre outras incumbências, a Constituição Federal de 1988 delegou ao Poder Público:

Art. 225. [...]

$\S 1$ o Para assegurar a efetividade desse direito, incumbe ao Poder Público:

[...]

III - definir, em todas as unidades da Federação, espaços territoriais e seus componentes a serem especialmente protegidos, sendo a alteração e a supressão permitidas somente através de lei, vedada qualquer utilização que comprometa a integridade dos atributos que justifiquem sua proteção; (Brasil, 1988, art. 225, inciso III).

Foi assim então que a criação de áreas protegidas e unidades de conservação foram alçadas como política pública dos Governos Federal, Estaduais e Municipais no Brasil, cabendo à Lei dos Crimes Ambientais, Lei no 9.605/1998 (Brasil, 1998), capitular os crimes relacionados aos danos provocados em unidades de conservação (Corrêa e Abreu, 2014). Assim capitula os arts. 40 e 40-A, da Lei no 9.605/1998, com redação dada pela Lei no 9.985/2000 (Brasil, 2000), nos casos indicados:

Art. 40. Causar dano direto ou indireto às Unidades de Conservação e às áreas de que trata o art. 27 do Decreto no 99.274, de 6 de junho de 1990, independentemente de sua localização:

Pena - reclusão, de um a cinco anos.

$\S 1$ o Entende-se por Unidades de Conservação de Proteção Integral as Estações Ecológicas, as Reservas Biológicas, os Parques Nacionais, os Monumentos Naturais e os Refúgios de Vida Silvestre. (Redação dada pela Lei no 9.985, de 2000)

$\S 2$ o A ocorrência de dano afetando espécies ameaçadas de extinção no interior das Unidades de Conservação de Proteção Integral será considerada circunstância agravante para a fixação da pena. (Redação dada pela Lei no 9.985, de 2000)

$\S 3$ o Se o crime for culposo, a pena será reduzida à metade.

Art. 40-A. (VETADO) (Incluído pela Lei no 9.985, de 2000)

$\S 1$ o Entende-se por Unidades de Conservação de Uso Sustentável as Áreas de Proteção Ambiental, as Áreas de Relevante Interesse Ecológico, as Florestas Nacionais, as Reservas Extrativistas, as Reservas de Fauna, as Reservas de Desenvolvimento Sustentável e as Reservas Particulares do Patrimônio Natural. (Incluído pela Lei no 9.985, de 2000)

$\S 2^{\circ}$ A ocorrência de dano afetando espécies ameaçadas de extinção no interior das Unidades de Conservação de Uso Sustentável será considerada circunstância agravante para a fixação da pena. (Incluído pela Lei no 9.985, de 2000)

$\S 3$ o Se o crime for culposo, a pena será reduzida à metade. (Incluído pela Lei no 9.985, de 2000) (Brasil, 2000).

Ao Decreto no 3.179/1999 (Brasil, 1999), revogado pelo Decreto no 6.514/2008 (Brasil, 2008), e modificado pelo Decreto no 6.686/2008 (Brasil, 2008), coube dispor sobre as infrações e sanções administrativas ao meio ambiente em unidades de conservação:

Art. 91. Causar dano à unidade de conservação: (Redação dada pelo Decreto no 6.686, de 2008).

Multa de $\mathrm{R} \$ 200,00$ (duzentos reais) a $\mathrm{R} \$ 100.000,00$ (cem mil reais). (Brasil, 2008). 
Embora a criação de unidades de conservação no Brasil como instrumento para a conservação da biodiversidade não seja recente, esta incumbência do Poder Público foi apenas regulamentada pela Lei no 9.985/2000, que instituiu o Sistema Nacional de Unidades de Conservação (SNUC) (Brasil, 2000), estabelecendo todos os procedimentos a serem adotados na criação, implantação e gestão destas unidades.

\section{Sistema de unidades de conservação (SNUC)}

Tentando disciplinar as áreas legalmente protegidas criadas no Brasil, a Resolução CONAMA no 11/1987 (Brasil, 1987) declarou como unidades de conservação os sítios ecológicos de relevância cultural, criadas por atos do poder público, como as estações ecológicas, as reservas ecológicas, as áreas de proteção ambiental, especialmente suas zonas de vida silvestre e os corredores ecológicos, os parques nacionais, estaduais e municipais, as reservas biológicas, as florestas nacionais, estaduais e municipais, os monumentos naturais, os jardins botânicos, os jardins zoológicos, bem como os hortos florestais.

Mas foi o Sistema Nacional de Unidades de Conservação (SNUC), instituído pela Lei no 9.985/2000 (Brasil, 2000), que estabeleceu os objetivos, as diretrizes, as atribuições dos órgãos envolvidos na sua gerência, bem como todos os procedimentos a serem adotados na criação, implantação e gestão destas unidades, no âmbito das esferas federal, estaduais e municipais.

De acordo com o art. $2^{\circ}$, inciso I, da Lei no 9.985/2000 (Brasil, 2000), entende-se por unidade de conservação:

Art. 2º Para os fins previstos nesta Lei, entende-se por:

I - unidade de conservação: espaço territorial e seus recursos ambientais, incluindo as águas jurisdicionais, com características naturais relevantes, legalmente instituído pelo Poder Público, com objetivos de conservação e limites definidos, sob regime especial de administração, ao qual se aplicam garantias adequadas de proteção; (Brasil, 2000).

Os principais méritos da Lei no 9.985/2000 (Brasil, 2000) foi a institucionalização do conceito de unidade de conservação, a divisão das categorias em proteção integral e uso sustentável (PAZ et al., 2006), a interrupção de criação de unidades de conservação sem relevâncias técnico-científicas, nos termos adotados por Jorge Pádua (1997), "causuísta e aleatória", bem como a padronização das categorias até então criadas por atos legais (Tabela 1).

Tabela 1. Categorias de unidades de conservação criadas anteriormente à sanção do Sistema Nacional de Unidades de Conservação (Lei no 9.885/2000).

\begin{tabular}{|c|c|}
\hline Unidade de Conservação & Ato legal \\
\hline Reserva Florestal & Decreto no $8.843 / 1911$ \\
\hline Parque Nacional & Lei no 4771/1965 \\
\hline Floresta Nacional & Lei no $4771 / 1965$ \\
\hline Reserva Biológica & Lei $n^{\circ} 5.197 / 1967$ \\
\hline Estação Ecológica & Lei $n^{0} 5.197 / 1967$ \\
\hline Áreas de Proteção Ambiental & Lei $n^{0}$ 6.902/1981 \\
\hline Reserva Econômica & Decreto $\mathrm{n}^{0} 89.336 / 1984$ \\
\hline Área de Relevante Interesse Ecológico & Decreto no 89.336/1984 \\
\hline Reserva Ecológica & Decreto $\mathrm{n}^{0} 89.336 / 1984$ \\
\hline
\end{tabular}


O Sistema Nacional de Unidades de Conservação (SNUC) dividiu as categorias de unidades de conservação em dois grupos, as unidades de proteção integral (Estação Ecológica, Reserva Biológica, Parque Nacional, Monumento Natural, Refúgio de Vida Silvestre) e as unidades de uso sustentável (Área de Proteção Ambiental, Área de Relevante Interesse Ecológico, Floresta Nacional, Reserva Extrativista, Reserva de Fauna, Reserva de Desenvolvimento Sustentável e Reserva Particular do Patrimônio Natural), cada uma com características e objetivos de manejo bem específicos (Brasil, 2000, arts. 7ํㅡ, 8ㅇ e 14).

Embora seja uma unidade de conservação de uso sustentável, a Reserva Particular do Patrimônio Natural (RPPN), por apenas permitir o uso indireto dos recursos naturais, permitindo-se as pesquisas e o ecoturismo, na prática ela se assemelha a uma unidade de conservação de proteção integral (Oliveira e Barbosa, 2010; Silva, 2008).

Assim, com o advento da Lei $\mathrm{n}^{0}$ 9.985/2000 (Brasil, 2000), todos os órgãos públicos estaduais e municipais que desejem integrar ao Sistema Nacional de Unidades de Conservação (SNUC) devem seguir literalmente o que determina esta norma, estipulando-se prazo de até dois anos, a contar da data de sanção da norma, para serem recategorizadas:

\footnotetext{
Art. 55. As unidades de conservação e áreas protegidas criadas com base nas legislações anteriores e que não pertençam às categorias previstas nesta Lei serão reavaliadas, no todo ou em parte, no prazo de até dois anos, com o objetivo de definir sua destinação com base na categoria e função para as quais foram criadas, conforme o disposto no regulamento desta Lei. (Brasil, 2000).
}

De acordo com o art. 6º, parágrafo único, da Lei no 9.985/2000, excepcionalmente e a critério do Conselho Nacional de Meio Ambiente (CONAMA), poderão integrar ao SNUC, as "unidades de conservação estaduais e municipais que foram concebidas para atender a peculiaridades regionais ou locais" e que "possuam objetivos de manejo que não possam ser satisfatoriamente atendidos por nenhuma categoria prevista" na Lei no 9.985/2000 "e cujas características permitam, em relação às criadas pelo SNUC, uma clara distinção" (Brasil, 2000, art. 6º , parágrafo único).

Cabendo ao Instituto Chico Mendes de Conservação da Biodiversidade (ICMBio), criada especificamente para administrar as unidades de conservação federais pela conversão da Medida Provisória no 366/2007 (Brasil, 2007) na Lei no 11.516/2007 (Brasil, 2007), e ao Instituto Brasileiro do Meio Ambiente e dos Recursos Naturais Renováveis (IBAMA), e em caráter supletivo, aos órgãos estaduais e municipais de meio ambiente, a execução do Sistema Nacional de Unidades de Conservação (SNUC), "com a função de implementá-lo, subsidiar as propostas de criação e administrar as unidades de conservação federais, estaduais e municipais, nas respectivas esferas de atuação" (Brasil, 2000, art. 6으, inciso III).

As categorias de unidades de conservação poderão ter, conforme o art. 29, da Lei no 9.985/2000 (Brasil, 2000), e art. 17, do Decreto no 4.340/2002 (Brasil, 2002), "conselho consultivo ou deliberativo, que serão presididos pelo chefe da unidade", que designará os demais conselheiros indicados pelos setores a serem representados, devendo ter representantes de órgãos públicos dos três níveis da federação, da comunidade científica, da sociedade civil, como a população residente, população tradicional, povos indígenas, proprietários de imóveis no interior da unidade de conservação, trabalhadores e setor privado atuantes na região, e organizações não-governamentais com atuação comprovada na região. 
De acordo com o art. 20, do Decreto no 4.340/2002 (Brasil, 2002), compete aos Conselhos Gestores:

Art. 20. Compete ao conselho de unidade de conservação:

I - elaborar o seu regimento interno, no prazo de noventa dias, contados da sua instalação;

II - acompanhar a elaboração, implementação e revisão do Plano de Manejo da unidade de conservação, quando couber, garantindo o seu caráter participativo;

III - buscar a integração da unidade de conservação com as demais unidades e espaços territoriais especialmente protegidos e com o seu entorno;

IV - esforçar-se para compatibilizar os interesses dos diversos segmentos sociais relacionados com a unidade;

$\mathrm{V}$ - avaliar o orçamento da unidade e o relatório financeiro anual elaborado pelo órgão executor em relação aos objetivos da unidade de conservação;

VI - opinar, no caso de conselho consultivo, ou ratificar, no caso de conselho deliberativo, a contratação e os dispositivos do termo de parceria com OSCIP, na hipótese de gestão compartilhada da unidade;

VII - acompanhar a gestão por OSCIP e recomendar a rescisão do termo de parceria, quando constatada irregularidade;

VIII - manifestar-se sobre obra ou atividade potencialmente causadora de impacto na unidade de conservação, em sua zona de amortecimento, mosaicos ou corredores ecológicos; e

IX - propor diretrizes e ações para compatibilizar, integrar e otimizar a relação com a população do entorno ou do interior da unidade, conforme o caso. (Brasil, 2002).

Outra importante inovação da lei do Sistema Nacional de Unidades de Conservação (SNUC), regulamentada pelo Decreto no 4.340/2002, foi disciplinar a criação de unidades de conservação, obrigando que o ato de criação seja o mais detalhado possível, contendo a denominação, a categoria de manejo, os objetivos, os limites, devidamente georreferenciados, a área e o órgão responsável pela administração, dentre outros itens (Brasil, 2002, art. 2º ). Também obrigou que a criação da unidade só poderá ser concretizada, após a elaboração de estudos técnicos preliminares (Brasil, 2002, art. 3ㅇ) atestando a importância da unidade, bem como após a realização de audiência pública (Farena, 2007), com a finalidade de subsidiar a definição da localização, da dimensão e dos limites mais adequados para a unidade (Brasil, 2002, art. 4ํㅜ), além do fornecimento de "informações adequadas e inteligíveis à população local e a outras partes interessadas" (Brasil, 2000, art. 22, § 3ํㅜ).

\section{Plano de manejo e zona de amortecimento das unidades de conservação}

Com o intuito de orientar o gerenciamento das unidades de conservação, a lei do Sistema Nacional de Unidades de Conservação (SNUC) (Lei no 9.985/2000) determinou a elaboração de um plano de manejo em até cinco após a criação da unidade, "devendo abranger a área da unidade de conservação, sua zona de amortecimento e os corredores ecológicos, incluindo medidas com o fim de promover sua integração à vida econômica e social das comunidades vizinhas" (Brasil, 2000, art. 27).

0 art. $2^{\circ}$, inciso VIII, da lei do Sistema Nacional de Unidades de Conservação (SNUC) (Lei no 9.985/2000) conceitua plano de manejo como:

Art. $2^{\circ}$ Para os fins previstos nesta Lei, entende-se por:

$[\ldots]$

XVII - plano de manejo: documento técnico mediante o qual, com fundamento nos

objetivos gerais de uma unidade de conservação, se estabelece o seu zoneamento e 
as normas que devem presidir o uso da área e o manejo dos recursos naturais, inclusive a implantação das estruturas físicas necessárias à gestão da unidade; (Brasil, 2000).

Considerando a importância do plano de manejo para a gestão da unidade de conservação, a lei do Sistema Nacional de Unidades de Conservação (SNUC) (Lei no 9.985/2000) proíbe "quaisquer alterações, atividades ou modalidades de utilização, nas unidades de conservação, em desacordo com os seus objetivos, o seu Plano de Manejo e seus regulamentos" (Brasil, 2000, art.28). Determinando ainda que, "até que seja elaborado o Plano de Manejo, todas as atividades e obras desenvolvidas nas unidades de conservação de proteção integral devem se limitar àquelas destinadas a garantir a integridade dos recursos naturais que a unidade objetiva proteger, assegurando-se às populações tradicionais porventura residentes na área as condições e os meios necessários para a satisfação de suas necessidades materiais, sociais e culturais" (Brasil, 2000, art. 28, parágrafo único).

O Instituto Brasileiro de Desenvolvimento Florestal (IBDF, 1979) assim conceitua o plano de manejo:

Plano de Manejo é o instrumento que fornece diretrizes básicas para o planejamento de uma unidade de conservação. Os recursos da unidade são analisados dentro do contesto nacional e regional, e seus objetivos específicos definidos. 0 zoneamento é uma maneira de garantir que a unidade atenda todos os objetivos determinados. Assim, seus programas de manejo e áreas de desenvolvimento são estabelecidos em ordem cronológica para que todos objetivos sejam alcançados.

Como o planejamento é um processo dinâmico, o plano de manejo deve ser flexível para incorporar novas descobertas científicas ou outras alterações que direta ou indiretamente possam refletir nos recursos da unidade de conservação. (IBDF, 1979, p. 5).

Além de proteger a área da unidade de conservação propriamente dita, a lei do Sistema Nacional de Unidades de Conservação (SNUC) (Lei no 9.985/2000) também impôs restrição às áreas adjacentes à unidade de modo a conferir maior efetividade à conservação e preservação da área, zona de amortecimento (Guimarães et al., 2012).

0 art. $2^{\circ}$, inciso XVIII, da lei do Sistema Nacional de Unidades de Conservação (SNUC) (Lei no 9.985/2000) assim conceitua zona de amortecimento:

Art. 2o Para os fins previstos nesta Lei, entende-se por:

$[\ldots]$

XVIII - zona de amortecimento: o entorno de uma unidade de conservação, onde as atividades humanas estão sujeitas a normas e restrições específicas, com o propósito de minimizar os impactos negativos sobre a unidade; (Brasil, 2000).

Coube ao Conselho Nacional do Meio Ambiente (CONAMA) através da Resolução CONAMA no 428/2010 (Brasil, 2010), alterada pela Resolução CONAMA no (Brasil, 2015), regulamentar a zona de amortecimento das unidades de conservação, a qual deve estar estabelecida no plano de manejo, no prazo de até cinco anos a partir da data da publicação da Resolução no 473/2015 (Brasil, 2015).

De acordo ainda com estas resoluções do CONAMA (Brasil, 2010; 2015), a zona de amortecimento para as unidades de conservação que não a estabeleceram será de três mil metros, para o licenciamento de empreendimentos de significativo impacto ambiental, assim considerados pelo órgão ambiental licenciador, com fundamento em Estudo de 
Impacto Ambiental e respectivo Relatório de Impacto Ambiental (EIA/RIMA). Nos casos dos empreendimentos não sujeitos a EIA/RIMA, a zona de amortecimento será estabelecida em dois mil metros.

\section{Material e métodos}

\section{Delimitação e caracterização da área de estudo}

Para este estudo, foram consideradas as unidades de conservação localizadas na Região Semiárida do Brasil, de acordo com os critérios técnicos e científicos estabelecidos pela Resolução SUDENE/CONDEL no 107/2017 e aprovados pela Resolução SUDENE/ CONDEL no 115/2017.

De acordo com a Resolução SUDENE/CONDEL no 107/2017, do Conselho Deliberativo (CONDEL) da Superintendência do Desenvolvimento do Nordeste (SUDENE), para compor a região semiárida, os municípios devem possuir as seguintes características climáticas:

Art. 2º Estabelecer os seguintes critérios técnicos e científicos para delimitação do Semiárido:

I - Precipitação pluviométrica média anual igual ou inferior a $800 \mathrm{~mm}$;

II - Índice de Aridez de Thorntwaite igual ou inferior a 0,50;

III - Percentual diário de déficit hídrico igual ou superior a $60 \%$, considerando todos os dias do ano (Brasil, 2017).

Estas características climáticas, de tipo BSh, pela classificação de Köppen (Alvares et al., 2014), favorecem o desenvolvimento da vegetação de Caatinga, com árvores e arbustos de porte baixo, folhas pequenas e espinhos e plantas suculentas (Andrade-Lima, 1981; Silva et al., 2016), e aliada às características pedológicas da região, tornam a Região Semiárida do Brasil susceptíveis ao processo de desertificação (Santana, 2007).

Atualmente, a Região Semiárida do Brasil engloba 1.262 municípios contíguos, pertencentes aos Estados do Maranhão, Piauí, Ceará, Rio Grande do Norte, Paraíba, Pernambuco, Alagoas, Sergipe, Bahia e Minas Gerais. A distribuição dos municípios por estados que compõe esta região, bem como a área abrangida e a população atingida são apresentadas na Tabela 2 e plotadas na Figura 1.

Tabela 2. Distribuição dos municípios por estados que compõem a Região Semiárida do Brasil.

\begin{tabular}{|c|c|c|c|c|}
\hline Estado & $\begin{array}{c}\text { Municípios } \\
\text { atingidos pelo } \\
\text { semiárido } \\
\end{array}$ & $\begin{array}{c}\text { Área total } \\
\left(\mathrm{km}^{2}\right)\end{array}$ & $\begin{array}{l}\text { Área semiárido } \\
\left(\mathbf{k m}^{2}\right)\end{array}$ & Pop 2017 \\
\hline Maranhão & 2 & $329.642,170$ & $3.523,12$ & 213.693 \\
\hline Piauí & 185 & $251.616,823$ & $200.610,03$ & 2.805 .394 \\
\hline Ceará & 175 & $148.894,757$ & $146.888,76$ & 5.827 .192 \\
\hline Rio Grande do Norte & 147 & $52.809,602$ & $49.072,54$ & 1.922 .440 \\
\hline Paraíba & 194 & $56.467,239$ & $51.305,67$ & 2.498 .117 \\
\hline Pernambuco & 123 & $98.068,021$ & $86.340,61$ & 3.993 .975 \\
\hline Alagoas & 38 & $27.843,295$ & $12.583,08$ & 962.641 \\
\hline Sergipe & 29 & $21.926,908$ & $11.093,04$ & 478.935 \\
\hline Bahia & 278 & $564.722,611$ & $446.021,34$ & 7.675 .656 \\
\hline Minas Gerais & 91 & $586.521,121$ & $121.259,21$ & 1.492 .198 \\
\hline Total & 1.262 & & $1.128 .697,40$ & 27.870 .241 \\
\hline
\end{tabular}

Fonte: Resolução CONDEL nº 107/2017 (Brasil, 2017). 


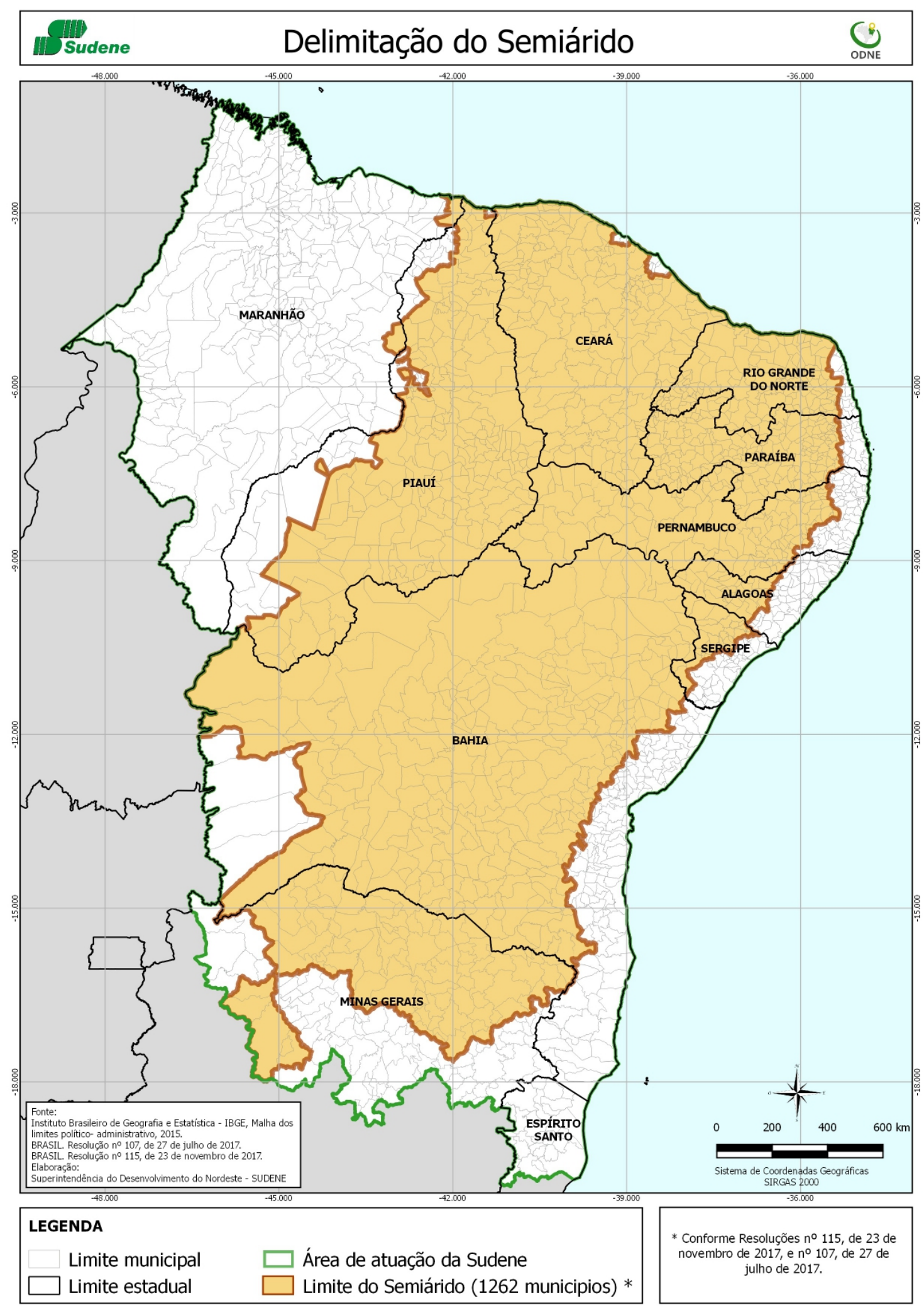

Figura 1. Delimitação da Região Semiárida no Brasil. Fonte: Resolução CONDEL no 107/2017 (Brasil, 2017), IBGE (2019). 


\section{As unidades de conservação}

Para a realização deste trabalho foi realizado levantamento bibliográfico, bem como foram consultados os partais da Internet para pesquisar as informações gerais sobre as unidades de conservação localizadas na Região Semiárida do Brasil, criadas até 31 de dezembro de 2019.

As fontes primárias para a pesquisa foram o Ministério do Meio Ambiente (MMA), o Instituto Chico Mendes de Conservação da Natureza (ICMBio), o Instituto Brasileiro de Meio Ambiente e dos Recursos Ambientais Renováveis (IBAMA) e o Diário Oficial da União. Além dos portais governamentais estaduais e municipais.

Para a obtenção de informações relacionadas ao status de conservação das unidades de conservação pesquisadas, foram realizadas buscas nos portais de revistas científicas usando-se como referência o nome da unidade de conservação.

\section{Resultados e discussão}

A Região Semiárida do Brasil atinge 10 estados e 1.262 municípios e em todas as unidades da federação foram criadas alguma categoria de unidades de conservação. A Tabela 3 mostra as unidades da federação com suas respectivas áreas, as áreas atingidas e o percentual de áreas do semiárido protegidas.

Tabela 3. Percentagem da área territorial estadual abrangida pela Região Semiárida em cada unidade da federação.

\begin{tabular}{|l|c|c|c|c|c|}
\hline Estado & $\begin{array}{c}\text { Área total } \\
\left(\mathbf{k m}^{\mathbf{2}} \mathbf{)}\right.\end{array}$ & $\begin{array}{c}\text { Área } \\
\text { Semiárido } \\
\left(\mathbf{k m}^{\mathbf{2}} \mathbf{)}\right.\end{array}$ & $\begin{array}{c}\mathbf{\%} \\
\text { Semiárido }\end{array}$ & $\begin{array}{c}\text { Área UC } \\
\text { Semiárido } \\
\text { (ha) }\end{array}$ & $\begin{array}{c}\text { \% UC } \\
\text { Semiárido }\end{array}$ \\
\hline Maranhão & $329.642,170$ & $3.523,12$ & 1,07 & $37.709,00$ & 10,70 \\
\hline Piauí & $251.616,823$ & $200.610,03$ & 79,73 & $2.480 .744,25$ & 12,37 \\
\hline Ceará & $148.894,757$ & $146.888,76$ & 98,65 & $1.205 .956,73$ & 8,31 \\
\hline $\begin{array}{l}\text { Rio Grande do } \\
\text { Norte }\end{array}$ & $52.809,602$ & $49.072,54$ & 92,92 & $26.767,48$ & 0,55 \\
\hline Paraíba & $56.467,239$ & $51.305,67$ & 90,86 & $68.595,34$ & 1,34 \\
\hline Pernambuco & $98.068,021$ & $86.340,61$ & 88,04 & $590.577,60$ & 6,84 \\
\hline Alagoas & $27.843,295$ & $12.583,08$ & 45,19 & $13.987,00$ & 1,11 \\
\hline Sergipe & $21.926,908$ & $11.093,04$ & 50,59 & $11.431,76$ & 1,03 \\
\hline Bahia & $564.722,611$ & $446.021,34$ & 78,98 & $2.904 .695,89$ & 6,51 \\
\hline Minas Gerais & $586.521,121$ & $121.259,21$ & 20,67 & $231.443,80$ & 0,19 \\
\hline Total & - & $\mathbf{1 . 1 2 8 . 6 9 7 , 4 0}$ & - & $\mathbf{7 . 5 7 1 . 9 0 8 , 8 5}$ & $\mathbf{6 , 7 1}$ \\
\hline
\end{tabular}

Fonte: Resolução CONDEL no 107/2017 (Brasil, 2017), IBGE (2019).

Para Leal et al. (2005) a criação de unidades de conservação, como estratégia regional para evitar as perdas de habitat e evitar a desertificação, além de manter os serviços ambientais oferecidos pelo Bioma da Caatinga e promover o uso sustentável dos recursos naturais da região, é essencial para reverter a degradação deste ecossistema.

Estudos recentes demonstram o grande potencial da Região Semiárida do Brasil em acolher uma biodiversidade significativa, inclusive albergando um grande número de espécies endêmicas. Para se ter uma ideia da biodiversidade da vegetação arbustivo-arbórea da Caatinga, em um pequeno trecho de mata ciliar do Rio Taperoá, na Região 
Semiárida da Paraíba, Lacerda e Barbosa (2008) identificaram 40 morfo-espécies, distribuídas em 21 famílias e 33 gêneros.

A criação de unidades de conservação na Região Semiárida do Brasil reveste-se ainda mais de importância quando se observa o uso da fauna silvestre como recurso alimentar e medicamentos (Mendonça et al., 2011; Alves et al., 2012) e o uso de plantas medicinais (Coutinho et al., 2015; Lucena et al., 2018), tendo em vista que todos tem o direito de usufruir destes recursos naturais.

\section{Unidades de conservação na região semiárida do Estado do Maranhão}

O Estado do Maranhão possui 10,70\% (Tabela 3) de sua área atingida pela Região do Semiárido (Figura 2) ocupada por quatro unidades de conservação, todas de uso sustentável, sendo uma administrada por órgão da esfera federal, uma particular e duas estaduais (Tabela 4).

A Área de Proteção Ambiental do Delta do Parnaíba, criada pelo governo federal, localizada no Município de Araioses, também está inserida em territórios do Estado de Ceará e do Estado do Piauí.

Tabela 4. Unidades de conservação (UC) na região semiárida do Estado do Maranhão.

\begin{tabular}{|c|c|c|c|c|c|}
\hline UC & Município & Tipo & Âmbito & Área (ha) & Ato de criação \\
\hline $\begin{array}{l}\text { RPPN Ilha do } \\
\text { Caju }\end{array}$ & Araioses & US & Federal & 102,00 & $\begin{array}{l}\text { Portaria IBAMA } \\
\text { no 96-N/1999 }\end{array}$ \\
\hline $\begin{array}{l}\text { APA Foz do Rio } \\
\text { das Preguiças - } \\
\text { Pequenos } \\
\text { Lençóis } \\
\text { Região Lagunar } \\
\text { Adjacente }\end{array}$ & $\begin{array}{c}\text { Araioses, } \\
\text { Barreirinhas, Tutóia, } \\
\text { Água Doce do } \\
\text { Maranhão }\end{array}$ & US & Estadual & $9.009,00$ & $\begin{array}{l}\text { Decreto } \quad n^{\circ} \\
11.899 / 1991\end{array}$ \\
\hline \begin{tabular}{ll|} 
APA dos \\
Morros \\
Garapenses
\end{tabular} & $\begin{array}{c}\text { Afonso Cunha, Buriti, } \\
\text { Coelho Neto, Duque } \\
\text { Bacelar }\end{array}$ & US & Estadual & $24.798,00$ & $\begin{array}{l}\text { Decreto } \quad \text { no } \\
25.087 / 2010\end{array}$ \\
\hline $\begin{array}{l}\text { APA Delta do } \\
\text { Parnaíba }\end{array}$ & $\begin{array}{c}\text { Paulino Neves, Tutóia, } \\
\text { Água Doce do } \\
\text { Maranhão, Araioses }\end{array}$ & US & Federal & $3.800,00$ & $\begin{array}{l}\text { Decreto } \\
\text { S/No/1996 }\end{array}$ \\
\hline Total & - & - & - & $37.709,00$ & - \\
\hline
\end{tabular}

Fonte: Brasil (2017), IBGE (2019). Legenda: APA = Área de Proteção Ambiental. RPPN = Reserva Particular do Patrimônio Natural. US = Uso sustentável. 


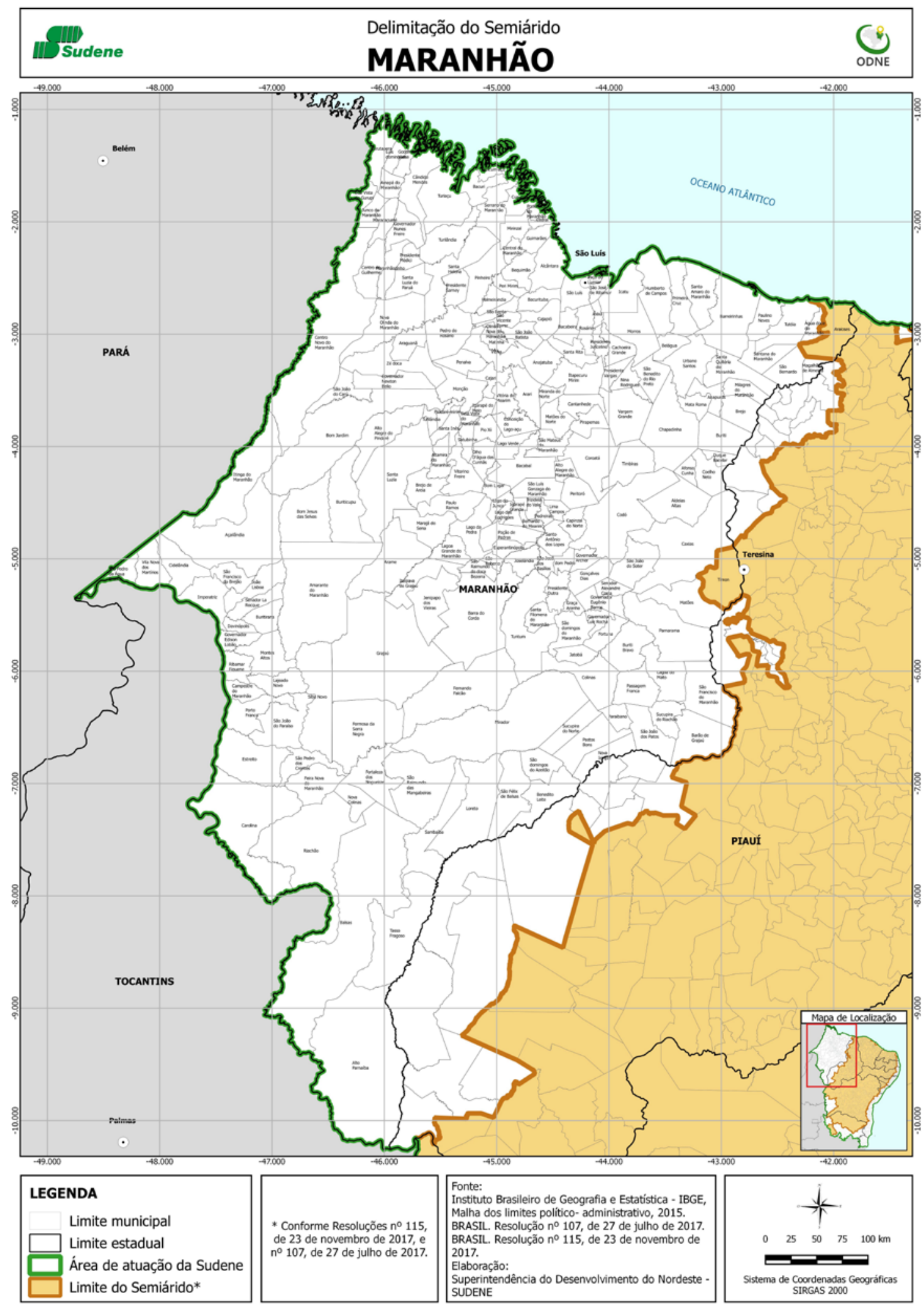

Figura 2. Delimitação da Região Semiárida no Estado do Maranhão. Fonte: Resolução CONDEL n⿳o 107/2017 (Brasil, 2017), IBGE (2019). 


\section{Unidades de conservação na região semiárida do Estado do Piauí}

O Estado do Piauí possui 12,37\% (Tabela 3) de sua área atingida pela Região do Semiárido (Figura 3) ocupada por 18 unidades de conservação, sendo quatro de proteção integral e 14 de uso sustentável, sendo oito administradas pelo governo federal, seis geridas por particulares e quatro pelo governo estadual (Tabela 5).

A Área de Proteção Ambiental da Serra da Ibiapaba, criada pelo governo federal, localizada nos Municípios de Bom Princípio do Piauí, Brasileira, Buriti dos Lopes, Cocal, Conceição do Canindé, Domingos Mourão, Lagoa de São Francisco, Piracuruca, Piripiri, Pedro II, também está inserida no Estado do Ceará.

A Área de Proteção Ambiental do Delta do Parnaíba, criada pelo governo federal, localizada nos Município de Delta do Parnaíba, Ilha Grande, Luís Correia, Parnaíba, Cajueiro da Praia, também compartilha territórios nos Estados do Maranhão e no Estado do Ceará.

A Área de Proteção Ambiental da Chapada do Araripe, criada pelo governo federal, localizado nos Municípios de Fronteiras, Padre Marcos, São Julião, Simões, Caldeirão Grande do Piauí, Alegrete do Piauí, Marcolândia, Caridade do Piauí, Curral Novo do Piauí e Francisco Macedo, também compartilha territórios nos Estados do Ceará e Estado de Pernambuco.

Tabela 5. Unidades de conservação (UC) na região semiárida do Estado do Piauí.

\begin{tabular}{|c|c|c|c|c|c|}
\hline UC & Município & Tipo & Âmbito & Área (ha) & Ato de criação \\
\hline $\begin{array}{l}\text { PARNA Serra da } \\
\text { Capivara }\end{array}$ & $\begin{array}{l}\text { Canto do Buriti, São } \\
\text { João do Piauí, São } \\
\text { Raimundo Nonato e } \\
\text { Coronel José Dias }\end{array}$ & PI & Federal & $100.762,00$ & $\begin{array}{l}\text { Decreto } \mathrm{n}^{\text {o }} \\
83.548 / 1979 \\
\text { Decreto } \mathrm{n}^{\text {o }} \\
99.143 / 1990\end{array}$ \\
\hline $\begin{array}{l}\text { PARNA Serra das } \\
\text { Confusões }\end{array}$ & $\begin{array}{c}\text { Caracol, Guaribas, Santa } \\
\text { Luz, Cristino Castro }\end{array}$ & PI & Federal & 823.838 & $\begin{array}{l}\text { Decreto } \\
\text { S/No/1998 } \\
\text { Decreto } \\
\text { S/No/2010 }\end{array}$ \\
\hline \begin{tabular}{ll|} 
PARNA & Sete \\
Cidades & \\
\end{tabular} & Piripiri e Piracuruca & PI & Federal & $6.303,64$ & $\begin{array}{l}\text { Decreto } \quad n^{\circ} \\
50.744 / 1961\end{array}$ \\
\hline FLONA Palmares & Altos e Teresina & US & Federal & 160,00 & $\begin{array}{l}\text { Decreto } \\
\text { S/No/2005 }\end{array}$ \\
\hline $\begin{array}{l}\text { RESEX Marinha } \\
\text { do Delta do } \\
\text { Parnaíba }\end{array}$ & Ilha Grande & US & Federal & 718,00 & $\begin{array}{l}\text { Decreto } \\
\text { S/No/2000 }\end{array}$ \\
\hline $\begin{array}{l}\text { APA da Cachoeira } \\
\text { do Urubu }\end{array}$ & Esperantina e Batalha & PI & Estadual & 3.053 & \begin{tabular}{|ll} 
Lei & $\mathrm{n}^{\text {o }}$ \\
$9.736 / 1997$ & \\
\end{tabular} \\
\hline APA Ingazeiras & Paulistana & US & Estadual & 653,97 & $\begin{array}{l}\text { Decreto } n^{\circ} \\
10.003 / 1999\end{array}$ \\
\hline $\begin{array}{l}\text { APA Lagoa de } \\
\text { Nazaré }\end{array}$ & Nazaré do Piauí & US & Estadual & $2.310,00$ & \begin{tabular}{|ll} 
Decreto & $n^{0}$ \\
$8.923 / 1993$ & \\
\end{tabular} \\
\hline APA Rangel & Curimatá & US & Estadual & $26.769,13$ & \begin{tabular}{|ll} 
Decreto & $\mathrm{n}^{\mathrm{o}}$ \\
$9.927 / 1998$ & \\
\end{tabular} \\
\hline
\end{tabular}


Tabela 5. Continuação.

\begin{tabular}{|c|c|c|c|c|c|}
\hline UC & Município & Tipo & Âmbito & Área (ha) & Ato de criação \\
\hline $\begin{array}{l}\text { RPPN Fazenda } \\
\text { Boqueirão dos } \\
\text { Frades }\end{array}$ & Altos & US & Federal & 579,78 & $\begin{array}{l}\text { Portaria } \\
\text { IBAMA } \\
\text { 29-N/1998 }\end{array}$ \\
\hline $\begin{array}{l}\text { RPPN } \quad \text { Fazenda } \\
\text { Centro }\end{array}$ & Buriti dos Lopes & US & Federal & 139,06 & \begin{tabular}{|ll} 
Portaria & \\
IBAMA & $n^{\circ}$ \\
$68-N / 1999$ & \\
\end{tabular} \\
\hline $\begin{array}{l}\text { RPPN Fazenda } \\
\text { Boqueirão }\end{array}$ & Canavieira & US & Federal & 580,00 & $\begin{array}{ll}\text { Portaria } & \\
\text { IBAMA } & \text { no } \\
65-N / 1997 & \\
\end{array}$ \\
\hline RPPN Marvão & Castelo do Piaui & US & Federal & $5.096,86$ & $\begin{array}{l}\text { Portaria } \\
\text { IBAMA } \\
42 / 2000\end{array}$ \\
\hline $\begin{array}{l}\text { RPPN Recanto da } \\
\text { Serra Negra }\end{array}$ & Pircuruca & US & Federal & 179,16 & $\begin{array}{ll}\text { Portaria } & \\
\text { IBAMA } \\
37 / 2004\end{array}$ \\
\hline $\begin{array}{l}\text { RPPN Santa } \\
\text { Maria de Tapuã }\end{array}$ & Teresina & US & Federal & 238,00 & $\begin{array}{ll}\text { Portaria } & \\
\text { IBAMA } & \text { no } \\
98-N / 1999 & \\
\end{array}$ \\
\hline $\begin{array}{l}\text { APA Serra da } \\
\text { Ibiapaba }\end{array}$ & $\begin{array}{l}\text { Bom Princípio do Piauí, } \\
\text { Brasileira, Buriti dos } \\
\text { Lopes, Cocal, Conceição } \\
\text { do Canindé, Domingos } \\
\text { Mourão, Lagoa de São } \\
\text { Francisco, Piracuruca, } \\
\text { Piripiri, Pedro II }\end{array}$ & US & Federal & $1.246 .148,89$ & $\begin{array}{l}\text { Decreto } \\
\text { S/No/1996 }\end{array}$ \\
\hline $\begin{array}{l}\text { APA Delta do } \\
\text { Parnaíba }\end{array}$ & $\begin{array}{l}\text { Ilha Grande, Luís } \\
\text { Correia, Parnaíba, } \\
\text { Cajueiro da Praia }\end{array}$ & US & Federal & $101.034,50$ & $\begin{array}{l}\text { Decreto } \\
\text { S/No/1996 }\end{array}$ \\
\hline $\begin{array}{l}\text { APA Chapada do } \\
\text { Araripe }\end{array}$ & $\begin{array}{c}\text { Fronteiras, Padre } \\
\text { Marcos, São Julião, } \\
\text { Simões, Caldeirão } \\
\text { Grande do Piauí, } \\
\text { Alegrete do Piauí, } \\
\text { Marcolândia, Caridade } \\
\text { do Piauí, Curral Novo } \\
\text { do Piauí, Francisco } \\
\text { Macedo } \\
\end{array}$ & US & Federal & $162.180,26$ & $\begin{array}{l}\text { Decreto } \\
\text { S/No/1997 }\end{array}$ \\
\hline Total & - & - & - & $2.480 .744,25$ & - \\
\hline
\end{tabular}

Fonte: Brasil (2017), IBGE (2019). Legenda: APA = Área de Proteção Ambiental; ARIE = Área de Relevante Interessante Ecológico; ESEC = Estação Ecológica; FLONA = Floresta Nacional; MONA = Monumento Natural; PARNA = Parque Nacional; REBIO = Reserva Biológica; RESEX = Reserva Extrativista; REVIS = Refúgio da Vida Silvestre; RPPN = Reserva Particular do Patrimônio Natural. 


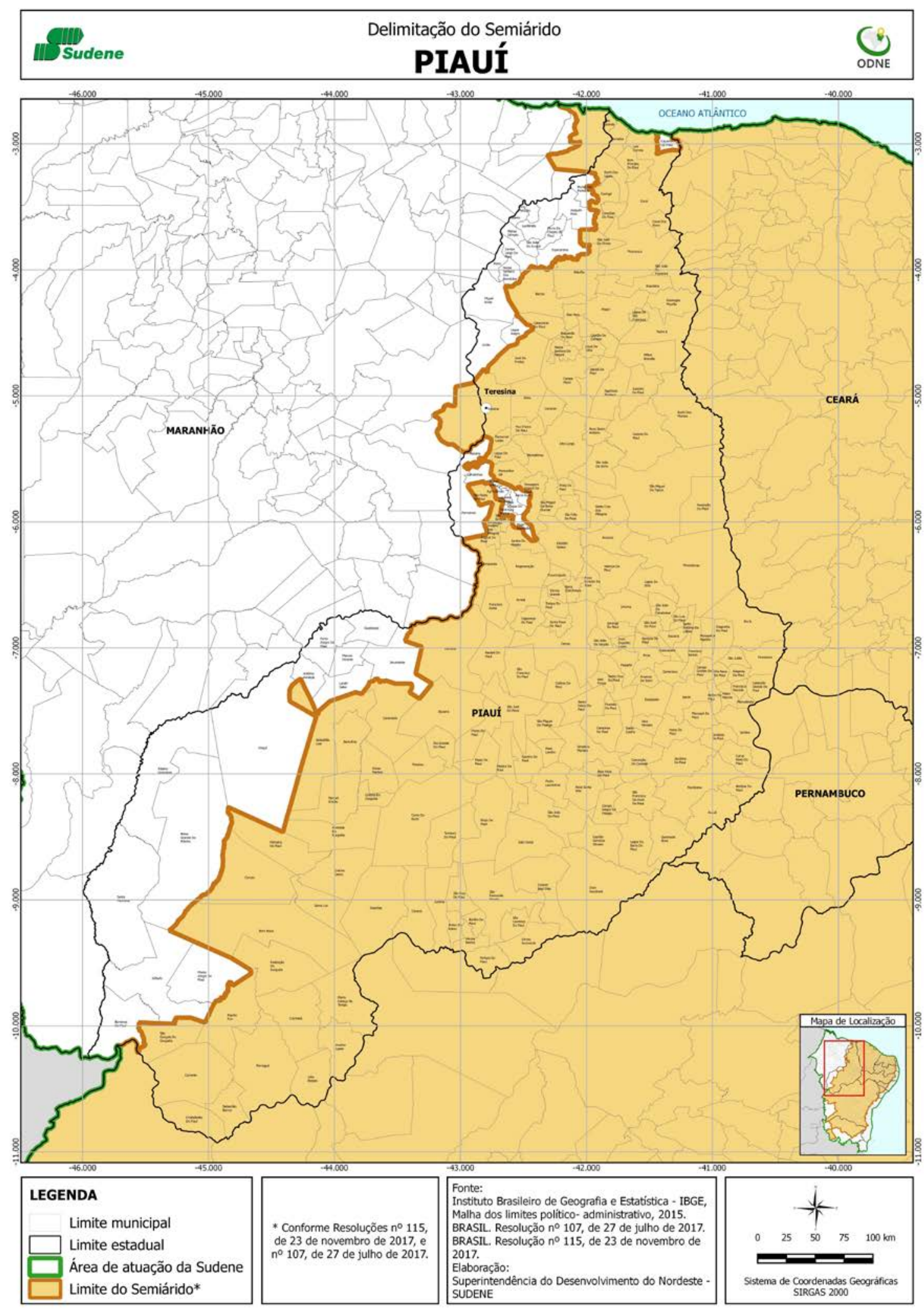

Figura 3. Delimitação da Região Semiárida no Estado do Piauí. Fonte: Resolução CONDEL noo 107/2017 (Brasil, 2017), IBGE (2019). 


\section{Unidades de conservação na região semiárida do Estado do Ceará}

O Estado do Ceará possui 8,21\% (Tabela 3) de sua área atingida pela Região do Semiárido (Figura 4) ocupada por 86 unidades de conservação, sendo 21 de proteção integral e 65 de uso sustentável, sendo 11 administradas pelo governo federal, 36 geridas por particulares, 25 pelo governo estadual, 10 pelos governos municipais e quatro reservas ecológicas particulares também com administração privada, mas pendendo de recategorização (Tabela 6).

A Área de Proteção Ambiental da Chapada do Arararipe, criada pelo governo federal, localizada nos Municípios de Abaiara, Araripe, Barbalha, Brejo Santo, Campos Sales, Crato, Jardim, Jati, Missão Velha, Nova Olinda, Penaforte, Porteiras, Potengi, Salitre, Santana do Cariri, também compartilha territórios no Estado de Pernambuco e no Estado do Piauí.

A Área de Proteção Ambiental do Delta do Parnaíba, criada pelo governo federal, localizada nos Municípios de Chaval e Barroquinha, também compartilha territórios no Estado do Piauí e no Estado do Maranhão.

A Área de Proteção Ambiental da Serra da Ibiapaba, criada pelo governo federal, localizada nos Municípios de Chaval, Granja, Moraújo, Tianguá e Viçosa do Ceará, também compartilha território no Estado do Piauí.

Tabela 6. Unidades de conservação (UC) na região semiárida do Estado do Ceará.

\begin{tabular}{|c|c|c|c|c|c|}
\hline $\mathrm{UC}$ & Município & Tipo & Âmbito & Área (ha) & Ato de criação \\
\hline $\begin{array}{l}\text { ESEC Açude } \\
\text { Castanhão }\end{array}$ & $\begin{array}{l}\text { Jaguaribara e Alto } \\
\text { Santo }\end{array}$ & PI & Federal & $12.579,20$ & \begin{tabular}{|l} 
Decreto \\
S/№/2001
\end{tabular} \\
\hline ESEC Aiuaba & Aiuaba & PI & Federal & $11.747,00$ & \begin{tabular}{|l} 
Decreto \\
S/№/2001 \\
\end{tabular} \\
\hline PARNA Ubajara & $\begin{array}{l}\text { Tianguá, } \\
\text { Frecherinha } \\
\text { Ubajara }\end{array}$ & PI & Federal & $6.288,00$ & $\begin{array}{l}\text { Decreto } \quad \mathrm{n}^{\mathrm{o}} \\
45.954 / 1959 \\
\text { Decreto } \\
\text { S/No/2002 }\end{array}$ \\
\hline $\begin{array}{l}\text { PARNA } \\
\text { Jericoacoara }\end{array}$ & \begin{tabular}{|l} 
Cruz, Jijoca de \\
Jericoacoara
\end{tabular} & PI & Federal & $8.416,08$ & \begin{tabular}{|l} 
Decreto \\
S/№/2002 \\
\end{tabular} \\
\hline $\begin{array}{l}\text { FLONA Araripe- } \\
\text { Apodi }\end{array}$ & $\begin{array}{|lr|}\text { Barbalha, } & \text { Crato, } \\
\text { Jardim, } & \text { Missão } \\
\text { Velha, Nova Olinda e } & \\
\text { Santana do Cariri }\end{array}$ & US & Federal & $38.918,00$ & $\begin{array}{l}\text { Decreto-Lei } \mathrm{n}^{\mathrm{o}} \\
9.226 / 1946 \\
\text { Decreto } \\
\text { S/No/2012 } \\
\end{array}$ \\
\hline FLONA Sobral & Sobral & US & Federal & 661,01 & $\begin{array}{ll}\text { Lei } & \text { no } \\
127 / 1947 & \\
\text { Decreto } & \mathrm{n}^{\circ} \\
62.007 / 1967 & \\
\text { Portaria } & \\
\text { ICMBio } & \mathrm{n}^{\circ} \mathrm{o} \\
358 / 2001 & \\
\end{array}$ \\
\hline $\begin{array}{l}\text { APA Serra da } \\
\text { Meruoca }\end{array}$ & $\begin{array}{l}\text { Alcântaras, Massapê, } \\
\text { Meruoca e Sobral }\end{array}$ & US & Federal & $29.361,00$ & $\begin{array}{l}\text { Lei } \mathrm{n}^{\mathrm{o}} \\
11.891 / 2008\end{array}$ \\
\hline
\end{tabular}


Tabela 6. Continuação.

\begin{tabular}{|c|c|c|c|c|c|}
\hline UC & Município & Tipo & Âmbito & Área (ha) & Ato de criação \\
\hline $\begin{array}{l}\text { APA Chapada do } \\
\text { Arararipe }\end{array}$ & $\begin{array}{lr}\text { Abaiara, } & \text { Araripe, } \\
\text { Barbalha, } & \text { Brejo } \\
\text { Santo, } & \text { Campos } \\
\text { Sales, Crato, Jardim, } \\
\text { Jati, Missão } & \text { Velha, } \\
\text { Novar } & \text { Olinda, } \\
\text { Penaforte, Porteiras, } \\
\text { Potengi, Salitre e } \\
\text { Santana do Cariri }\end{array}$ & US & Federal & $532.236,17$ & $\begin{array}{l}\text { Decreto } \\
\text { S/№/1997 }\end{array}$ \\
\hline $\begin{array}{l}\text { APA Delta do } \\
\text { Parnaíba }\end{array}$ & $\begin{array}{l}\text { Chaval e } \\
\text { Barroquinha }\end{array}$ & US & Federal & $20.904,76$ & $\begin{array}{l}\text { Decreto } \\
\text { S/No/1996 }\end{array}$ \\
\hline $\begin{array}{l}\text { APA Serra da } \\
\text { Ibiapaba }\end{array}$ & \begin{tabular}{|l|} 
Chaval, $\quad$ Granja, \\
Moraújo, Tianguá e e \\
Viçosa do Ceará
\end{tabular} & US & Federal & $346.401,11$ & $\begin{array}{l}\text { Decreto } \\
\text { S/N№/1996 }\end{array}$ \\
\hline RESEX Batoque & Aquiraz & US & Federal & 601,05 & $\begin{array}{l}\text { Decreto } \\
\text { S/No/2003 }\end{array}$ \\
\hline ESEC Pacém & \begin{tabular}{|lrr} 
Caucaia & e & São \\
Gonçalo & & do \\
Amarante & & \\
\end{tabular} & PI & Estadual & 964,00 & $\begin{array}{l}\text { Decreto } \mathrm{n}^{\underline{0}} \\
30.895 / 2012\end{array}$ \\
\hline $\begin{array}{l}\text { MONA Monólitos } \\
\text { de Quixada }\end{array}$ & Quixada & PI & Estadual & $28.782,00$ & $\begin{array}{l}\text { Decreto } n^{\circ} \\
26.805 / 2002\end{array}$ \\
\hline $\begin{array}{l}\text { MONA Falésias de } \\
\text { Beberibe }\end{array}$ & Beberibe & PI & Estadual & 31,29 & $\begin{array}{l}\text { Decreto } n^{\text {o }} \\
27.461 / 2004\end{array}$ \\
\hline $\begin{array}{l}\text { Parque Estadual } \\
\text { do Cocó }\end{array}$ & Fortaleza & PI & Estadual & $1.564,00$ & $\begin{array}{l}\text { Decreto } \mathrm{n}^{\mathrm{o}} \\
32.248 / 2017\end{array}$ \\
\hline $\begin{array}{l}\text { Parque Botânico } \\
\text { Estadual Ceará }\end{array}$ & Caucaia & PI & Estadual & 190,00 & $\begin{array}{l}\text { Decreto } n^{\text {o }} \\
24.216 / 1996\end{array}$ \\
\hline $\begin{array}{l}\text { Parque Estadual } \\
\text { Marinho da Pedra } \\
\text { da Risca do Meio }\end{array}$ & Fortaleza & PI & Estadual & $3.320,00$ & $\begin{array}{l}\text { Lei } \\
12.717 / 1997\end{array}$ \\
\hline $\begin{array}{l}\text { Parque Estadual } \\
\text { Carnaúbas }\end{array}$ & $\begin{array}{l}\text { Granja e Viçosa do } \\
\text { Ceará }\end{array}$ & PI & Estadual & $10.005,00$ & $\begin{array}{l}\text { Decreto } n^{\text {o }} \\
28.154 / 2006\end{array}$ \\
\hline $\begin{array}{l}\text { MONA Sítio Cana } \\
\text { Brava }\end{array}$ & Santana do Cariri & PI & Estadual & 18,00 & $\begin{array}{l}\text { Decreto } n^{\text {o }} \\
28.506 / 2006\end{array}$ \\
\hline $\begin{array}{l}\text { MONA Sítio Riacho } \\
\text { do Meio }\end{array}$ & Barbalha & PI & Estadual & 15,00 & $\begin{array}{l}\text { Decreto } n^{\text {o }} \\
28.506 / 2006\end{array}$ \\
\hline $\begin{array}{l}\text { REVIS Periquito } \\
\text { Cara-Suja }\end{array}$ & Guaramiranga & PI & Estadual & 39,00 & $\begin{array}{l}\text { Decreto } n^{\circ} \\
32.791 / 2018\end{array}$ \\
\hline $\begin{array}{l}\text { ARIE das Águas } \\
\text { Emendadas } \\
\text { Inhamuns }\end{array}$ & $\begin{array}{l}\text { Independência, } \\
\text { Pedra Branca e Tauá }\end{array}$ & US & Estadual & 407,00 & $\begin{array}{l}\text { Decreto } \mathrm{n}^{\text {o }} \\
31.403 / 2014 \mathrm{De} \\
\text { creto } \mathrm{n}^{\mathrm{o}} \\
32.162 / 2017\end{array}$ \\
\hline ARIE do Cambeba & Fortaleza & US & Estadual & 11,00 & $\begin{array}{l}\text { Decreto } n^{\text {o }} \\
32.843 / 2018\end{array}$ \\
\hline
\end{tabular}


Tabela 6. Continuação.

\begin{tabular}{|c|c|c|c|c|c|}
\hline UC & Município & Tipo & Âmbito & Área (ha) & Ato de criação \\
\hline APA Bica do Ipu & Ipu & US & Estadual & $3.484,66$ & $\begin{array}{l}\text { Decreto } \\
25.354 / 1999\end{array}$ \\
\hline $\begin{array}{l}\text { APA das Dunas da } \\
\text { Lagoinha }\end{array}$ & Paraipaba & US & Estadual & 498,00 & $\begin{array}{l}\text { Decreto } n^{\text {o }} \\
25.417 / 1999\end{array}$ \\
\hline $\begin{array}{l}\text { APA das Dunas de } \\
\text { Paracuru }\end{array}$ & Paracuru & US & Estadual & $3.909,60$ & $\begin{array}{l}\text { Decreto } n^{\text {o }} \\
25.418 / 1999\end{array}$ \\
\hline $\begin{array}{l}\text { APA do Estuário } \\
\text { do Rio Ceará - Rio } \\
\text { Maranguapinho }\end{array}$ & $\begin{array}{l}\text { Caucaia, Fortaleza, } \\
\text { Maracanaú, } \\
\text { Maranguape }\end{array}$ & US & Estadual & $3.447,00$ & $\begin{array}{l}\text { Decreto } \mathrm{n}^{\mathbf{0}} \\
25.413 / 1999 \\
\text { Decreto } \mathrm{n}^{\mathrm{o}} \\
32.761 / 2018\end{array}$ \\
\hline $\begin{array}{l}\text { APA Estuário do } \\
\text { Rio Curu }\end{array}$ & $\begin{array}{l}\text { Paracuru } \\
\text { Paraipaba }\end{array}$ & US & Estadual & 881,94 & $\begin{array}{l}\text { Decreto } n^{\text {o }} \\
25.416 / 1999\end{array}$ \\
\hline $\begin{array}{l}\text { APA Estuário do } \\
\text { Rio Mundaú }\end{array}$ & Trairi e Itapipoca & US & Estadual & $1.360,00$ & $\begin{array}{l}\text { Decreto } n^{\text {o }} \\
24.414 / 1999\end{array}$ \\
\hline $\begin{array}{l}\text { APA Lagamar do } \\
\text { Cauípe }\end{array}$ & Caucaia & US & Estadual & $1.691,00$ & $\begin{array}{l}\text { Decreto } \quad n^{0} \\
24.957 / 1998\end{array}$ \\
\hline $\begin{array}{l}\text { APA da Lagoa de } \\
\text { Jijoca }\end{array}$ & $\begin{array}{l}\text { Cruz e Jijoca de } \\
\text { Jericoacoara }\end{array}$ & US & Estadual & $3.945,00$ & $\begin{array}{l}\text { Decreto } \quad n^{\text {o }} \\
25.975 / 2000\end{array}$ \\
\hline $\begin{array}{ll}\text { APA Lagoa do } \\
\text { Uruaú }\end{array}$ & Beberibe & US & Estadual & $2.734,00$ & $\begin{array}{l}\text { Decreto } \\
25.355 / 1999\end{array}$ \\
\hline APA do Pacém & $\begin{array}{l}\text { São Gonçalo do } \\
\text { Amarante }\end{array}$ & US & Estadual & 122,79 & $\begin{array}{l}\text { Decreto } \quad n^{\circ} \\
24.957 / 1998\end{array}$ \\
\hline APA do Rio Pacoti & $\begin{array}{l}\text { Fortaleza, Eusébio e } \\
\text { Aquiraz }\end{array}$ & US & Estadual & $2.608,00$ & $\begin{array}{l}\text { Decreto } \quad n^{\text {o }} \\
25.778 / 2000\end{array}$ \\
\hline $\begin{array}{l}\text { APA da Serra da } \\
\text { Aratanha }\end{array}$ & $\begin{array}{l}\text { Maranguape, } \\
\text { Pacatuba e Guaiúba }\end{array}$ & US & Estadual & $6.453,00$ & $\begin{array}{l}\text { Decreto } \quad n^{\circ} \\
24.959 / 1998\end{array}$ \\
\hline $\begin{array}{l}\text { APA Serra de } \\
\text { Baturité }\end{array}$ & $\begin{array}{l}\text { Aratuba, Baturité, } \\
\text { Capistrano, } \\
\text { Guaramiranga, } \\
\text { Mulungu, Pacoti, } \\
\text { Palmácia } \\
\text { Redenção }\end{array}$ & US & Estadual & $32.690,00$ & $\begin{array}{l}\text { Decreto } \quad n \text { o } \\
20.956 / 1990\end{array}$ \\
\hline $\begin{array}{lr}\text { Parque } & \text { Natural } \\
\text { Municipal } & \text { das } \\
\text { Dunas } & \text { da } \\
\text { Sabiaguaba } & \\
\end{array}$ & Fortaleza & PI & Municipal & 468,00 & $\begin{array}{l}\text { Decreto } n^{\text {o }} \\
11.986 / 2006\end{array}$ \\
\hline $\begin{array}{lr}\text { Parque } & \text { Natural } \\
\text { Municipal } & \text { das } \\
\text { Timbaúbas } & \\
\end{array}$ & Juazeiro do Norte & PI & Municipal & 25,00 & $\begin{array}{l}\text { Decreto } \\
352 / 2017\end{array}$ \\
\hline $\begin{array}{l}\text { Parque Ecológico } \\
\text { Lagoa da Fazenda }\end{array}$ & Sobral & PI & Municipal & 19,00 & $\begin{array}{l}\text { Decreto } \\
21.303 / 1991\end{array}$ \\
\hline APA Balbino & Cascavel & US & Municipal & 250,00 & $\begin{array}{ll}\text { Lei } & n^{\text {o }} \\
479 / 1988 & \end{array}$ \\
\hline
\end{tabular}


Tabela 6. Continuação.

\begin{tabular}{|c|c|c|c|c|c|}
\hline UC & Município & Tipo & Âmbito & Área (ha) & Ato de criação \\
\hline $\begin{array}{ll}\text { APA } & \text { Canoa } \\
\text { Quebrada } & \\
\end{array}$ & Aracati & US & Municipal & $4.000,00$ & Lei nº 40/1998 \\
\hline $\begin{array}{l}\text { APA Lagoa da } \\
\text { Bastiana }\end{array}$ & Iguatu & US & Municipal & - & \begin{tabular}{|ll} 
Lei & $n^{\circ}$ \\
$170 / 1991$ & \\
\end{tabular} \\
\hline $\begin{array}{l}\text { APA do Manguezal } \\
\text { da Barra Grande }\end{array}$ & Icapuí & US & Municipal & $1.774,00$ & $\begin{array}{ll}\text { Lei } & n^{\circ} \\
298 / 2000 & \\
\text { Lei } & n^{\circ} \\
634 / 2014 & \end{array}$ \\
\hline APA Maranguape & Maranguape & US & Municipal & $65.480,00$ & $\begin{array}{ll}\text { Lei } & \mathrm{n}^{\mathrm{o}} \\
1.168 / 1993 & \end{array}$ \\
\hline $\begin{array}{l}\text { APA da Praia de } \\
\text { Ponta Grossa }\end{array}$ & Icapuí & US & Municipal & $1.487,00$ & $\begin{array}{ll}\text { Lei } & n^{\circ} \\
262 / 1998 & \\
\text { Lei } & n^{\circ} \\
633 / 2014 & \\
\end{array}$ \\
\hline $\begin{array}{l}\text { APA Lagoa da } \\
\text { Maraponga }\end{array}$ & Juazeiro do Norte & US & Municipal & 31,00 & $\begin{array}{ll}\text { Lei } & \mathrm{n}^{\mathrm{o}} \\
6.833 / 1991 & \\
\text { Decreto } & \mathrm{n}^{\mathrm{o}} \\
14.389 / 2019 & \end{array}$ \\
\hline REP Jandaíra & Trairí & PI & Estadual & 54,53 & $\begin{array}{l}\text { Portaria } \\
\text { SEMACE } \quad \text { no } \\
234 / 2002\end{array}$ \\
\hline $\begin{array}{l}\text { REP Lagoa da } \\
\text { Sapiranga }\end{array}$ & Fortaleza & PI & Estadual & 58,76 & $\begin{array}{l}\text { Portaria } \\
\text { SEMACE } \quad \text { no } \\
031 / 1997\end{array}$ \\
\hline REP Mata Fresca & Meruoca & PI & Estadual & 107,90 & $\begin{array}{l}\text { Portaria } \\
\text { SEMACE } \quad \text { no } \\
92 / 2004\end{array}$ \\
\hline $\begin{array}{l}\text { REP Sítio do Olho } \\
\text { d'Água }\end{array}$ & Baturité & PI & Estadual & 383,34 & $\begin{array}{l}\text { Portaria } \\
\text { SEMACE } \\
222 / 2000\end{array}$ \\
\hline $\begin{array}{l}\text { RPPN Fazenda } \\
\text { Mercês Sabiaquaba } \\
\text { e Nazario }\end{array}$ & Amontada & US & Federal & 50,00 & $\begin{array}{l}\text { Portaria IBAMA } \\
\text { no } 113 / 1993\end{array}$ \\
\hline $\begin{array}{ll}\text { RPPN } & \text { Cícero } \\
\text { Almeida } & \end{array}$ & Apuiarés & US & Federal & 36,00 & $\begin{array}{l}\text { Portaria ICMBio } \\
\text { no } 216 / 2013\end{array}$ \\
\hline $\begin{array}{ll}\text { RPPN } & \text { Ilha } \\
\text { Encantada } & \\
\end{array}$ & Aracati & US & Federal & 18,60 & $\begin{array}{l}\text { Portaria ICMBio } \\
\text { no } 257 / 2013\end{array}$ \\
\hline $\begin{array}{l}\text { RPPN Reserva da } \\
\text { Cultura } \\
\text { Permanente }\end{array}$ & Aratuba & US & Federal & 7,62 & $\begin{array}{l}\text { Portaria ICMBio } \\
\text { n 91/2011 }\end{array}$ \\
\hline RPPN Arajara Park & Barbalha & US & Federal & 27,81 & $\begin{array}{l}\text { Portaria IBAMA } \\
\text { no } 24 / 1999\end{array}$ \\
\hline $\begin{array}{lr}\text { RPPN } & \text { Reserva } \\
\text { Natural } & \text { Sítio } \\
\text { Palmeiras } & \\
\end{array}$ & Baturité & US & Federal & 75,47 & $\begin{array}{ll}\text { Portaria } & n^{\circ} \\
\text { ICMBio } & n^{\circ} \\
46 / 2008 & \end{array}$ \\
\hline
\end{tabular}


Tabela 6. Continuação.

\begin{tabular}{|c|c|c|c|c|c|}
\hline UC & Município & Tipo & Âmbito & Área (ha) & Ato de criação \\
\hline $\begin{array}{lll}\text { RPPN } & \text { Serra das } \\
\text { Almas } & & \end{array}$ & Cratéus & US & Federal & $5.845,47$ & $\begin{array}{l}\text { Portaria IBAMA } \\
\text { no 51/2000 } \\
\text { Portaria IBAMA } \\
\text { no } 117 / 2002 \\
\text { Portaria ICMBio } \\
\text { no } 36 / 2016\end{array}$ \\
\hline \begin{tabular}{|lr} 
RPPN & Reserva \\
Natural & Francisco \\
Braz de Oliveira \\
\end{tabular} & Crateús & US & Federal & 4,80 & $\begin{array}{l}\text { Portaria ICMBio } \\
\text { n- 237/2002 }\end{array}$ \\
\hline $\begin{array}{l}\text { RPPN Olho d'Água } \\
\text { do Tronco }\end{array}$ & Crateús & US & Federal & 48,62 & $\begin{array}{l}\text { Portaria ICMBio } \\
\text { no } 81 / 2016\end{array}$ \\
\hline \begin{tabular}{|ll} 
RPPN & Neném \\
Barros & \\
\end{tabular} & Crateús & US & Federal & 63,16 & $\begin{array}{l}\text { Portaria ICMBio } \\
\text { no 8/2012 }\end{array}$ \\
\hline $\begin{array}{ll}\text { RPPN } & \text { Chico } \\
\text { Bimbino } & \\
\end{array}$ & Crateús & US & Federal & 25,00 & $\begin{array}{l}\text { Portaria ICMBio } \\
\text { no } 16 / 2016\end{array}$ \\
\hline $\begin{array}{ll}\text { RPPN } & \text { Oásis } \\
\text { Araripe } & \end{array}$ & Crato & US & Federal & 50,00 & $\begin{array}{l}\text { Portaria ICMBio } \\
\text { no 33/2016 }\end{array}$ \\
\hline RPPN Araçá & Crato & US & Federal & 11,73 & $\begin{array}{l}\text { Portaria ICMBio } \\
\text { no } 113 / 2014\end{array}$ \\
\hline $\begin{array}{ll}\text { RPPN } & \text { Elias } \\
\text { Andrade } & \end{array}$ & Geraldo Sampaio & US & Federal & 207,92 & $\begin{array}{l}\text { Portaria ICMBio } \\
\text { no 93/2009 }\end{array}$ \\
\hline $\begin{array}{l}\text { RPPN } \\
\text { Ambientalista } \\
\text { Francy Nunes }\end{array}$ & Geraldo Sampaio & US & Federal & 200,00 & $\begin{array}{l}\text { Portaria IBAMA } \\
\text { no } 54 / 2000\end{array}$ \\
\hline $\begin{array}{l}\text { RPPN Chanceler } \\
\text { Edson Queiroz }\end{array}$ & Guaiúba & US & Federal & 129,61 & $\begin{array}{l}\text { Portaria IBAMA } \\
\mathrm{n}=5 / 2006\end{array}$ \\
\hline RPPN Gália & Guaramiranga & US & Federal & 55,98 & $\begin{array}{l}\text { Portaria ICMBio } \\
\text { no 69/2012 }\end{array}$ \\
\hline RPPN Sítio Lagoa & Guaramiranga & US & Federal & 70,00 & $\begin{array}{l}\text { Portaria ICMBio } \\
\text { no } 81 / 2018\end{array}$ \\
\hline \begin{tabular}{|ll} 
RPPN & Fazenda \\
Belém & \\
\end{tabular} & Icapuí & US & Federal & $2.982,55$ & $\begin{array}{l}\text { Portaria ICMBio } \\
\text { no } 134 / 2014 \\
\end{array}$ \\
\hline RPPN Mãe da Lua & Itapagé & US & Federal & 764,08 & $\begin{array}{l}\text { Portaria ICMBio } \\
\text { no 58/2009 }\end{array}$ \\
\hline 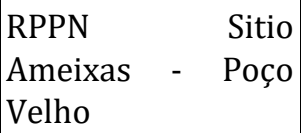 & Itapipoca & US & Federal & 464,33 & $\begin{array}{l}\text { Portaria IBAMA } \\
\text { no 7-N/1994 }\end{array}$ \\
\hline $\begin{array}{ll}\text { RPPN } & \text { Luizinho } \\
\text { Alencar } & \\
\end{array}$ & Itatira & US & Federal & 200,00 & $\begin{array}{l}\text { Portaria ICMBio } \\
n=186 / 2013\end{array}$ \\
\hline RPPN Fonte de Luz & Meruoca & US & Federal & 7,00 & $\begin{array}{l}\text { Portaria ICMBio } \\
n=258 / 2013\end{array}$ \\
\hline RPPN Vó Belar & Meruoca & US & Federal & 14,99 & $\begin{array}{l}\text { Portaria ICMBio } \\
\text { no } 217 / 2013\end{array}$ \\
\hline
\end{tabular}


Tabela 6. Continuação.

\begin{tabular}{|c|c|c|c|c|c|}
\hline UC & Município & Tipo & Âmbito & Área (ha) & Ato de criação \\
\hline $\begin{array}{ll}\text { RPPN } & \text { Samuel } \\
\text { Nobre } & \end{array}$ & Morada Nova & US & Federal & 27,00 & \begin{tabular}{|l} 
Portaria \\
ICMBio \\
$23 / 2014$
\end{tabular} \\
\hline RPPN Belo Monte & Mulungu & US & Federal & 15,70 & $\begin{array}{l}\text { Portaria } \\
\text { ICMBio } \\
97 / 2011\end{array}$ \\
\hline $\begin{array}{l}\text { RPPN Almirante } \\
\text { Renato de Miranda } \\
\text { Monteiro }\end{array}$ & Novo Oriente & US & Federal & 219,93 & \begin{tabular}{|l} 
Portaria \\
ICMBio \\
$111 / 2011$
\end{tabular} \\
\hline $\begin{array}{ll}\text { RPPN } & \text { Monte } \\
\text { Alegre } & \end{array}$ & Pacatuba & US & Federal & 263,00 & $\begin{array}{ll}\text { Portaria } & \\
\text { IBAMA } & \mathrm{n}^{\circ} \\
151 / 2001 & \end{array}$ \\
\hline $\begin{array}{l}\text { RPPN Serra } \\
\text { Pacavira }\end{array}$ & Pacoti & US & Federal & 33,56 & \begin{tabular}{|l} 
Portaria \\
ICMBio \\
$47 / 2018 \quad \mathrm{n}$ - \\
\end{tabular} \\
\hline $\begin{array}{ll}\text { RPPN } & \text { Passaredo } \\
\text { Pacoti } & \end{array}$ & Pacoti & US & Federal & 3,61 & \begin{tabular}{|l} 
Portaria \\
ICMBio $\quad \mathrm{n}$ 을 \\
$10 / 2012$
\end{tabular} \\
\hline \begin{tabular}{lrr} 
RPPN & \multicolumn{2}{r}{ Fazenda } \\
Olho & d'Âgua & do \\
Urucu & &
\end{tabular} & Parambu & US & Federal & $2.610,00$ & $\begin{array}{ll}\text { Portaria } & \\
\text { IBAMA } & \text { no } \\
719 / 1991 & \end{array}$ \\
\hline 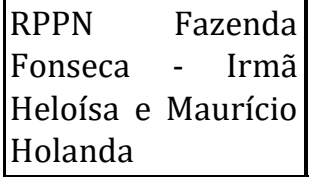 & Quixadá & US & Federal & 226,20 & \begin{tabular}{|l} 
Portaria \\
ICMBio \\
$664 / 2018 \quad$ no
\end{tabular} \\
\hline \begin{tabular}{|ll} 
RPPN & Fazenda \\
Arizona &
\end{tabular} & Quixadá & US & Federal & 216,70 & $\begin{array}{l}\text { Portaria } \\
\text { ICMBio } \\
264 / 2013\end{array}$ \\
\hline $\begin{array}{l}\text { RPPN Fazenda Não } \\
\text { Me Deixes }\end{array}$ & Quixadá & US & Federal & 300,00 & \begin{tabular}{|l} 
Portaria \\
IBAMA no $37-$ \\
N/1999
\end{tabular} \\
\hline RPPN Rio Bonito & Quixeramobim & US & Federal & 441,00 & \begin{tabular}{|l} 
Portaria \\
IBAMA \\
$174 / 2001$ \\
\end{tabular} \\
\hline $\begin{array}{l}\text { RPPN } \quad \text { Paulino } \\
\text { Velôso Camêlo }\end{array}$ & Tianguá & US & Federal & 120,19 & \begin{tabular}{|l} 
Portaria \\
ICMBio \\
$43 / 2010$ \\
\end{tabular} \\
\hline Total & - & - & - & $1.205 .956,73$ & - \\
\hline
\end{tabular}

Fonte: Brasil (2017); IBGE (2019). Legenda: APA = Área de Proteção Ambiental; ARIE = Área de Relevante Interessante Ecológico; ESEC = Estação Ecológica; FLONA = Floresta Nacional; MONA = Monumento Natural; PARNA = Parque Nacional; REBIO = Reserva Biológica; RESEX $=$ Reserva Extrativista; REVIS = Refúgio da Vida Silvestre; REP $=$ Reserva Ecológica Particular. RPPN $=$ Reserva Particular do Patrimônio Natural. 


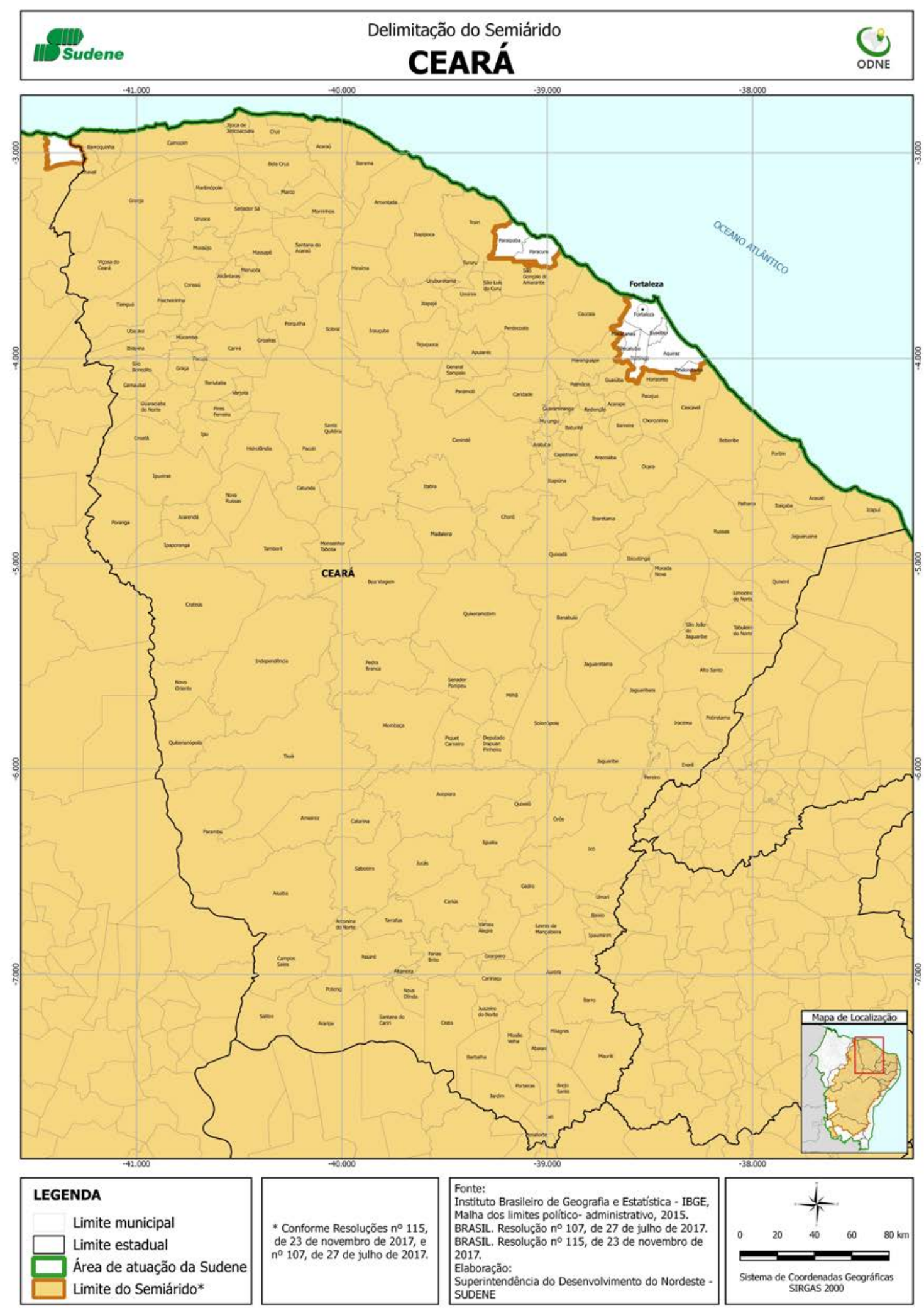

Figura 4. Delimitação da Região Semiárida no Estado do Ceará. Fonte: Resolução CONDEL n⿳o 107/2017 (Brasil, 2017), IBGE (2019). 


\section{Norte}

\section{Unidades de conservação na região semiárida do Estado do Rio Grande do}

O Estado do Rio Grande do Norte possui 0,55\% (Tabela 3) de sua área atingida pela Região do Semiárido (Figura 5) ocupada por 10 unidades de conservação, sendo três de proteção integral e sete de uso sustentável, sendo três administradas pelo governo federal, quatro geridas por particulares e duas pelo governo estadual (Tabela 7).

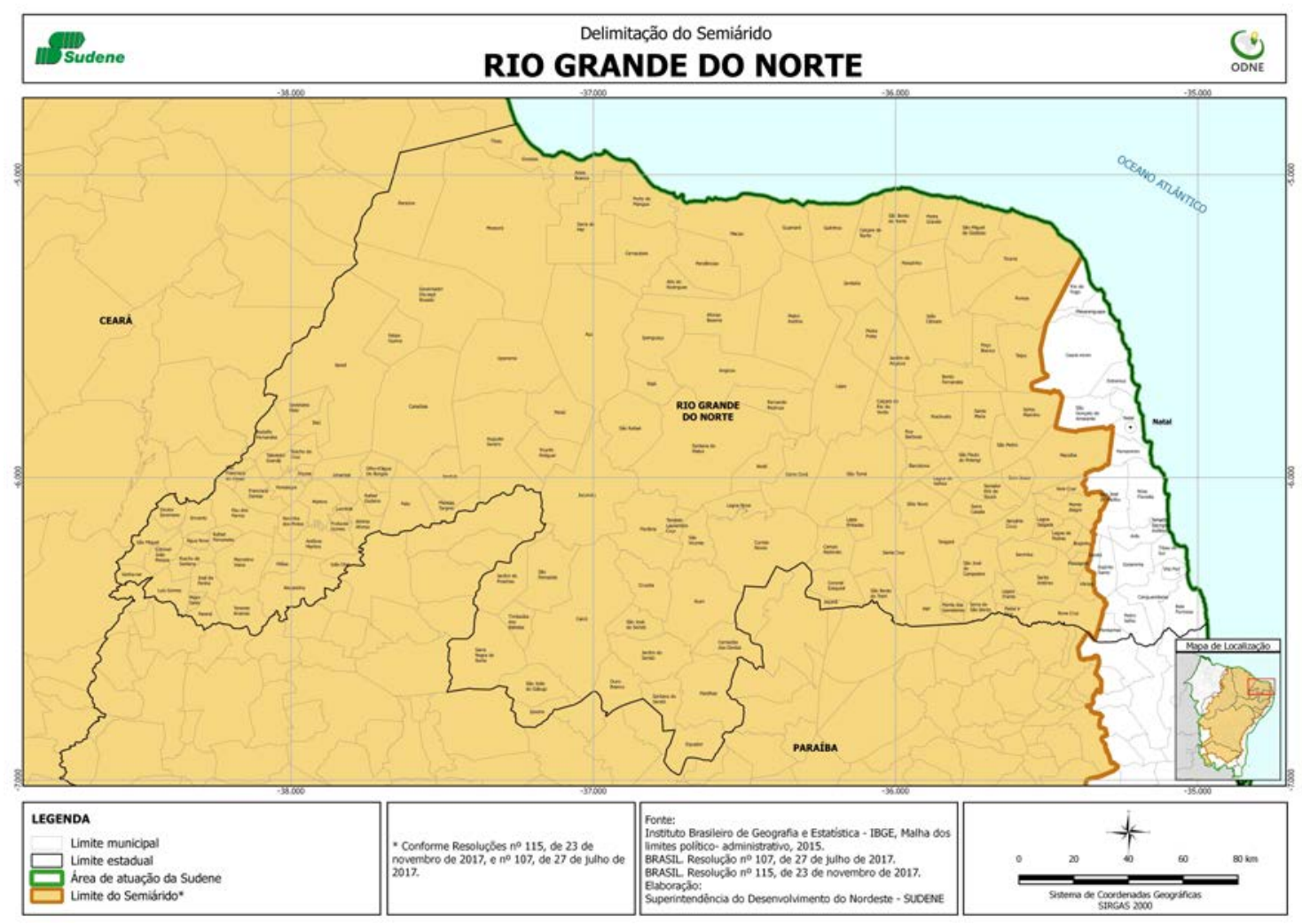

Figura 5. Delimitação da Região Semiárida no Estado do Rio Grande do Norte. Fonte: Resolução CONDEL no 107/2017 (Brasil, 2017), IBGE (2019).

Tabela 7. Unidades de conservação (UC) na região semiárida do Estado do Rio Grande do Norte.

\begin{tabular}{|l|c|c|c|l|l|}
\hline UC & Município & Tipo & Âmbito & Área (ha) & Ato de criação \\
\hline ESEC Seridó & Serra Negra do Norte & PI & Federal & $1.124,00$ & $\begin{array}{l}\text { Decreto } \\
87.222 / 1982\end{array}$ \\
\hline $\begin{array}{l}\text { PARNA da Furna } \\
\text { Feia }\end{array}$ & Baraúna e Mossoró & PI & Federal & $8.518,00$ & $\begin{array}{l}\text { Decreto } \\
\text { S/No/2012 }\end{array}$ \\
\hline FLONA Açu & Açu & US & Federal & 225,00 & $\begin{array}{l}\text { Lei } \\
1.175 / 1950 \\
\text { Portaria IBAMA } \\
\text { no 245/2001 }\end{array}$ \\
\hline $\begin{array}{l}\text { Parque Ecológico } \\
\text { Cabugi }\end{array}$ & Angicos & PI & Estadual & $2.164,00$ & $\begin{array}{l}\text { Decretor } \\
14.813 / 2000\end{array}$ \\
\hline
\end{tabular}

Rev. Bras. Gest. Amb. Sustent., 2020, vol. 7, n. 17, p. 1283-1334. 
Tabela 7. Continuação.

\begin{tabular}{|l|c|c|c|c|l|}
\hline UC & Município & Tipo & Âmbito & Área (ha) & Ato de criação \\
\hline $\begin{array}{l}\text { RDSE Ponta do } \\
\text { Tubarão }\end{array}$ & Guamaré e Macau & US & Estadual & $10.125,00$ & $\begin{array}{l}\text { Lei } \\
8.349 / 2003\end{array}$ \\
\hline $\begin{array}{l}\text { APA Piquiri-Una } \\
\text { Canguaretama, } \\
\text { Espírito Santo e Pedro } \\
\text { Velho }\end{array}$ & US & Estadual & $3.128,00$ & $\begin{array}{l}\text { Decreto } \\
10.683 / 1990 \\
\text { Decreto } \\
22.182 / 2011\end{array}$ \\
\hline RPPN Ser Nativo
\end{tabular}

Fonte: Brasil (2017); IBGE (2019). Legenda: APA = Área de Proteção Ambiental; ARIE = Área de Relevante Interessante Ecológico; ESEC = Estação Ecológica; FLONA = Floresta Nacional; MONA = Monumento Natural; PARNA = Parque Nacional; REBIO = Reserva Biológica; RESEX $=$ Reserva Extrativista; REVIS = Refúgio da Vida Silvestre; RPPN = Reserva Particular do Patrimônio Natural.

\section{Unidades de conservação na região semiárida do Estado da Paraíba}

O Estado da Paraíba possui 1,34\% (Tabela 3) de sua área atingida pela Região do Semiárido (Figura 6) ocupada por 18 unidades de conservação, sendo seis de proteção integral e 12 de uso sustentável, sendo nove administradas pelo governo estadual, nove geridas por particulares e uma pelo governo municipal (Tabela 8).

Tabela 8. Unidades de conservação (UC) na região semiárida do Estado da Paraíba.

\begin{tabular}{|l|l|l|l|l|l|}
\hline UC & Município & Tipo & Âmbito & Área (ha) & Ato de criação \\
\hline $\begin{array}{l}\text { MONA Vale dos } \\
\text { Dinossauros }\end{array}$ & Sousa & PI & Estadual & 40,00 & $\begin{array}{l}\text { Decreto } \\
23.832 / 2002\end{array}$ \\
\hline $\begin{array}{l}\text { Parque Estadual } \\
\text { Mata do Pau- } \\
\text { Ferro Areia }\end{array}$ & PI & Estadual & 607,00 & $\begin{array}{l}\text { Decreto no } \\
26.098 / 2005\end{array}$ \\
\hline $\begin{array}{l}\text { Parque Estadual } \\
\text { Pedra da Boca }\end{array}$ & Araruna & PI & Estadual & 157,26 & $\begin{array}{l}\text { Decreto } \\
20.889 / 2000\end{array}$ \\
\hline $\begin{array}{l}\text { Parque Estadual } \\
\text { Pico do Jabre }\end{array}$ & $\begin{array}{l}\text { Matureia e Mãe } \\
\text { d'Água }\end{array}$ & PI & Estadual & 851,00 & $\begin{array}{l}\text { Decreto } \\
23.060 / 2002\end{array}$ \\
\hline $\begin{array}{l}\text { Parque Estadual } \\
\text { Parque dos } \\
\text { Poetas }\end{array}$ & Campina Grande & PI & Estadual & 419,00 & $\begin{array}{l}\text { Decreto } \\
25.322 / 2004\end{array}$ \\
\hline
\end{tabular}


Tabela 8. Continuação.

\begin{tabular}{|c|c|c|c|c|c|}
\hline UC & Município & Tipo & Âmbito & Área (ha) & Ato de criação \\
\hline $\begin{array}{l}\text { APA Cachoeira do } \\
\text { Roncador }\end{array}$ & $\begin{array}{l}\text { Bananeira, Borborema } \\
\text { e Pirpirituba }\end{array}$ & US & Estadual & $6.113,00$ & $\begin{array}{l}\text { Decreto } n^{\text {o }} \\
27.204 / 2006\end{array}$ \\
\hline APA Cariri & Cabaceiras & US & Estadual & $18.560,00$ & $\begin{array}{l}\text { Decreto } \quad n^{\text {o }} \\
25.083 / 2004\end{array}$ \\
\hline APA Onças & São João do Tigre & US & Estadual & $36.000,00$ & $\begin{array}{l}\text { Decreto } n^{\text {o }} \\
22.880 / 2002\end{array}$ \\
\hline $\begin{array}{l}\text { ARIE Mata de } \\
\text { Goiamunduba }\end{array}$ & Bananeiras & US & Estadual & 67,00 & $\begin{array}{l}\text { Decreto } \mathrm{n}^{\mathbf{o}} \\
23.833 / 2002\end{array}$ \\
\hline $\begin{array}{l}\text { Parque Ecológico } \\
\text { Distrito } \\
\text { Engenheiro } \\
\text { Ávido }\end{array}$ & Cajazeiras & PI & Municipal & 181,98 & $\begin{array}{ll}\text { Lei } & \mathrm{n}^{\text {o }} \\
1.147 / 1997 & \end{array}$ \\
\hline $\begin{array}{ll}\text { RPPN } & \text { Fazenda } \\
\text { Almas } & \end{array}$ & São José dos Cordeiros & US & Federal & $3.505,00$ & $\begin{array}{l}\text { Portaria IBAMA } \\
\mathrm{n} \text { - } 1.343 / 1990\end{array}$ \\
\hline $\begin{array}{l}\text { RPPN Fazenda } \\
\text { Pedra d'Água }\end{array}$ & Solânea & US & Federal & 170,00 & $\begin{array}{l}\text { Portaria IBAMA } \\
\text { no } 60-\mathrm{N} / 1999 \\
\end{array}$ \\
\hline $\begin{array}{l}\text { RPPN Fazenda } \\
\text { Santa Clara }\end{array}$ & São João do Cariri & US & Federal & 750,50 & $\begin{array}{l}\text { Portaria IBAMA } \\
n=1344 / 1990\end{array}$ \\
\hline $\begin{array}{l}\text { RPPN Fazenda } \\
\text { Tamanduá }\end{array}$ & Santa Terezinha & US & Federal & 325,00 & $\begin{array}{l}\text { Portaria IBAMA } \\
\text { no } 110-\mathrm{N} / 1998\end{array}$ \\
\hline $\begin{array}{ll}\text { RPPN } & \text { Fazenda } \\
\text { Várzea } & \end{array}$ & Araruna & US & Federal & 390,66 & $\begin{array}{l}\text { Portaria IBAMA } \\
\text { no } 11-\mathrm{N} / 1998\end{array}$ \\
\hline $\begin{array}{l}\text { RPPN Major Badú } \\
\text { Loureiro }\end{array}$ & Catingueira & US & Federal & 186,31 & $\begin{array}{l}\text { Portaria IBAMA } \\
\mathrm{n} \text { - } 109 / 2001\end{array}$ \\
\hline RPPN Sítio Armil & São Mamede & US & Federal & 5,10 & $\begin{array}{l}\text { Portaria ICMBio } \\
n-195 / 2018\end{array}$ \\
\hline $\begin{array}{l}\text { RPPN Fazenda } \\
\text { Pacatuba }\end{array}$ & Sapé & US & Federal & 266,53 & $\begin{array}{l}\text { Portaria IBAMA } \\
\text { no } 110-\mathrm{N} / 1995\end{array}$ \\
\hline $\begin{array}{l}\text { RPPN Fazenda } \\
\text { Cabeça de Boi }\end{array}$ & Pocinhos & US & Estadual & 33,65 & $\begin{array}{l}\text { Portaria } \\
\text { SUDEMA } \\
30 / 2009\end{array}$ \\
\hline Total & - & - & - & $68.628,99$ & - \\
\hline
\end{tabular}

Fonte: Brasil (2017); IBGE (2019). Legenda: APA = Área de Proteção Ambiental; ARIE = Área de Relevante Interessante Ecológico; ESEC = Estação Ecológica; FLONA = Floresta Nacional; MONA = Monumento Natural; PARNA = Parque Nacional; REBIO = Reserva Biológica; RESEX = Reserva Extrativista; REVIS = Refúgio da Vida Silvestre; RPPN = Reserva Particular do Patrimônio Natural. 


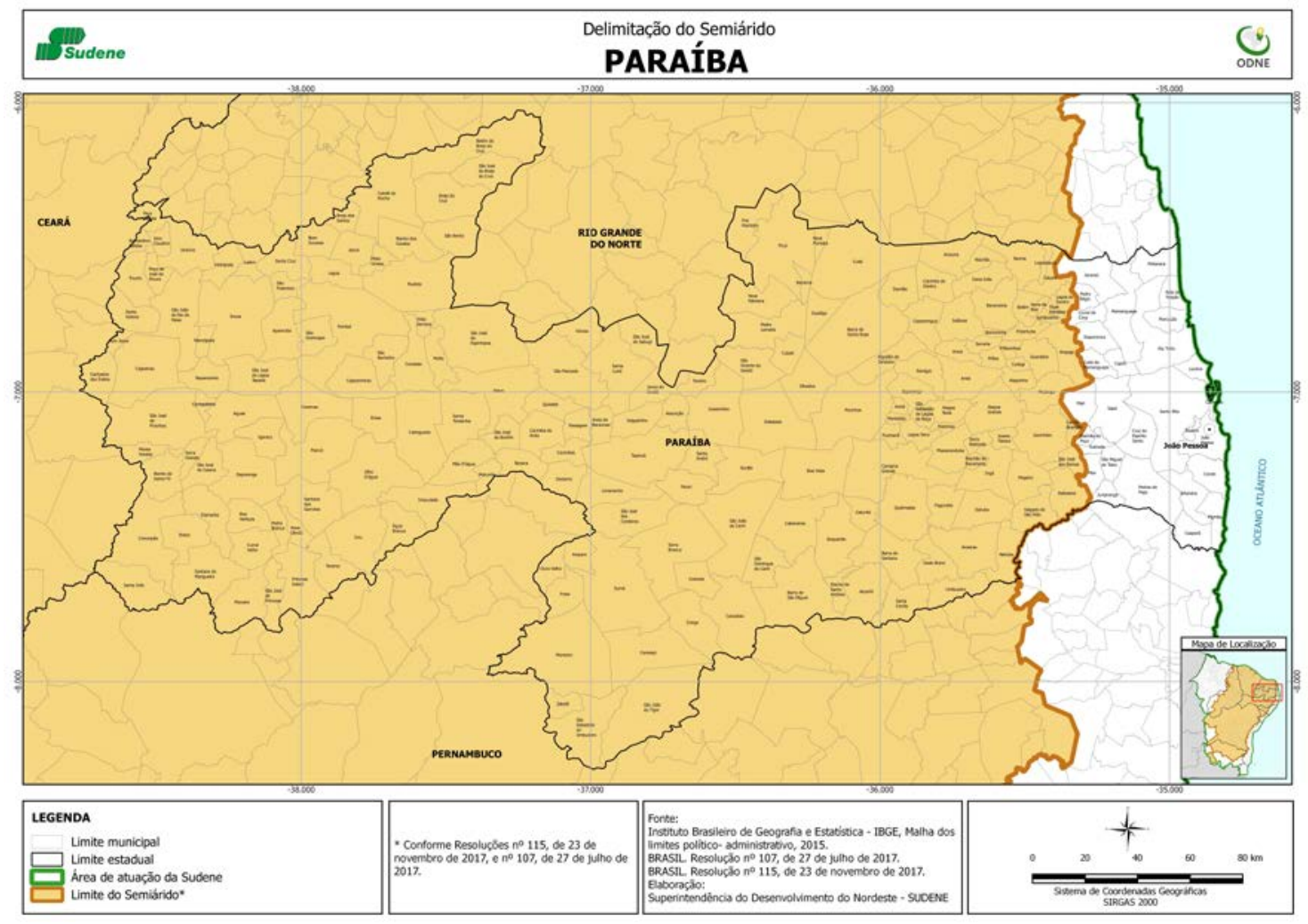

Figura 6. Delimitação da Região Semiárida no Estado da Paraíba. Fonte: Resolução CONDEL nํㅗ 107/2017 (Brasil, 2017), IBGE (2019).

\section{Unidades de conservação na região semiárida do Estado de Pernambuco}

0 Estado de Pernambuco possui 6,84\% (Tabela 3) de sua área atingida pela Região do Semiárido (Figura 7) ocupada por 25 unidades de conservação, sendo 14 de proteção integral e 11 de uso sustentável, das quais quatro são administradas pelo governo federal, 10 pelo governo estadual, nove geridas por particulares e duas pelo governo municipal (Tabela 9).

A Área de Proteção Ambiental da Chapada do Araripe, criada pelo governo federal, localizada nos Municípios de Araripina, Bodocó, Cedro, Exu, Ipubi, Serrita, Moreilândia, Trindade, compartiha territórios no Estado do Ceará e no Estado do Piauí.

Tabela 9. Unidades de conservação (UC) na região semiárida do Estado de Pernambuco.

\begin{tabular}{|l|c|c|c|c|l|}
\hline UC & Município & Tipo & Âmbito & Área (ha) & Ato de criação \\
\hline $\begin{array}{l}\text { PARNA Vale do } \\
\text { Catimbau }\end{array}$ & $\begin{array}{c}\text { Buique, Ibimirim e } \\
\text { Tupanatinga }\end{array}$ & PI & Federal & $62.294,14$ & $\begin{array}{l}\text { Decreto } \\
\text { S/No/2002 }\end{array}$ \\
\hline $\begin{array}{l}\text { REBIO Serra } \\
\text { Negra }\end{array}$ & $\begin{array}{c}\text { Floresta, Inajá e } \\
\text { Tacaratu }\end{array}$ & PI & Federal & $1.100,00$ & $\begin{array}{l}\text { Decreto } \\
87.591 / 1982\end{array}$ \\
\hline FLONA Negreiros & Serrita & US & Federal & $3.005,00$ & $\begin{array}{l}\text { Decreto } \\
\text { S/No/2006 }\end{array}$ \\
\hline
\end{tabular}


Tabela 9. Continuação.

\begin{tabular}{|c|c|c|c|c|c|}
\hline UC & Município & Tipo & Âmbito & Área (ha) & Ato de criação \\
\hline $\begin{array}{l}\text { APA Chapada do } \\
\text { Araripe }\end{array}$ & $\begin{array}{l}\text { Araripina, Bodocó, } \\
\text { Cedro, Exu, Ipubi, } \\
\text { Serrita, Moreilândia, } \\
\text { Trindade }\end{array}$ & US & Federal & $368.583,57$ & $\begin{array}{l}\text { Decreto } \\
\text { S/No/1997 }\end{array}$ \\
\hline $\begin{array}{l}\text { ESEC Serra da } \\
\text { Canoa }\end{array}$ & Floresta & PI & Estadual & $7.601,00$ & \begin{tabular}{|l} 
Decreto \\
$38.133 / 2012$
\end{tabular} \\
\hline $\begin{array}{l}\text { Parque Estadual } \\
\text { Mata } \\
\text { Pimenteira }\end{array}$ & Serra Talhada & PI & Estadual & 873,00 & $\begin{array}{l}\text { Decreto } \quad \mathrm{n}^{\mathrm{o}} \\
37.823 / 2012\end{array}$ \\
\hline $\begin{array}{l}\text { Parque Estadual } \\
\text { Serra do Areal }\end{array}$ & Petrolina & PI & Estadual & $1.597,00$ & \begin{tabular}{|l} 
Decreto \\
$37.823 / 2012$
\end{tabular} \\
\hline $\begin{array}{l}\text { MONA Pedra do } \\
\text { Cachorro }\end{array}$ & $\begin{array}{c}\text { Brejo da Madre de } \\
\text { Deus, São Caitano e } \\
\text { Tacaimbó }\end{array}$ & PI & Estadual & $1.376,00$ & $\begin{array}{l}\text { Decreto no } \\
40.549 / 2014\end{array}$ \\
\hline $\begin{array}{l}\text { REVIS Matas do } \\
\text { Siriji }\end{array}$ & São Vicente Ferrer & PI & Estadual & 645,00 & \begin{tabular}{|l} 
Decreto $\mathrm{n}^{\mathrm{o}}$ \\
$40.548 / 2014$ \\
\end{tabular} \\
\hline $\begin{array}{l}\text { REVIS Matas de } \\
\text { Água Azu }\end{array}$ & $\begin{array}{c}\text { Macaparana, } \\
\text { Timbaúba e Vicência }\end{array}$ & PI & Estadual & $3.484,00$ & $\begin{array}{l}\text { Decreto } \mathrm{n}^{\mathbf{o}} \\
40.551 / 2014\end{array}$ \\
\hline $\begin{array}{l}\text { REVIS Riacho do } \\
\text { Pontal }\end{array}$ & Petrolina & PI & Estadual & $4.820,00$ & \begin{tabular}{|l|} 
Decreto \\
$40.552 / 2014$ \\
\end{tabular} \\
\hline REVIS Tatu-Bola & $\begin{array}{c}\text { Petrolina, Lagoa } \\
\text { Grande e Santa Maria } \\
\text { da Boa Vista }\end{array}$ & PI & Estadual & $110.110,25$ & $\begin{array}{l}\text { Decreto } \quad n^{\circ} \\
41.546 / 2015\end{array}$ \\
\hline \begin{tabular}{ll|} 
REVIS Serra do \\
Giz
\end{tabular} & $\begin{array}{c}\text { Afogados da Ingazeira } \\
\text { e Carnaíba }\end{array}$ & PI & Estadual & 310,20 & $\begin{array}{l}\text { Decreto } \mathrm{n}^{\mathrm{o}} \\
47.557 / 2019 \\
\end{array}$ \\
\hline $\begin{array}{l}\text { REVIS Serras } \\
\text { Caatingueiras }\end{array}$ & Salgueiro e Cabrobó & PI & Estadual & $21.687,62$ & \begin{tabular}{|l|} 
Decreto no \\
$47.558 / 2019$ \\
\end{tabular} \\
\hline $\begin{array}{l}\text { Parque Ecológico } \\
\text { Serra Negra }\end{array}$ & Bezerros & PI & Municipal & 3,24 & \begin{tabular}{|l} 
Decretos Lei no \\
$36 / 1989$ \\
\end{tabular} \\
\hline $\begin{array}{l}\text { Parque Natural } \\
\text { Municipal } \\
\text { Professor João } \\
\text { Vasconcelos } \\
\text { Sobrinho }\end{array}$ & Caruaru & PI & Municipal & 352,00 & $\begin{array}{ll}\text { Lei } & \mathrm{n}^{\text {o }} \\
2.796 / 1983 & \\
\text { Lei } & \mathrm{n}^{\text {o }} \\
5.192 / 2012 & \end{array}$ \\
\hline $\begin{array}{l}\text { RPPN Reserva } \\
\text { Ecológica } \\
\text { Mauricio Dantas } \\
\end{array}$ & Betânia & US & Federal & $1.485,00$ & $\begin{array}{l}\text { Portaria IBAMA } \\
\text { 104-N/1997 }\end{array}$ \\
\hline \begin{tabular}{ll|} 
RPPN & Reserva \\
Natural & Brejo \\
\end{tabular} & Saloá & US & Federal & 52,39 & $\begin{array}{l}\begin{array}{l}\text { Portaria IBAMA } \\
\text { no } 90 / 2002\end{array} \\
\end{array}$ \\
\hline $\begin{array}{ll}\text { RPPN } & \text { Reserva } \\
\text { Jurema } & \\
\end{array}$ & $\begin{array}{c}\text { Belém do São } \\
\text { Francisco }\end{array}$ & US & Federal & 267,50 & $\begin{array}{l}\text { Portaria IBAMA } \\
\text { no } 33 / 2007 \\
\end{array}$ \\
\hline $\begin{array}{ll}\text { RPPN } & \text { Reserva } \\
\text { Siriema } & \\
\end{array}$ & $\begin{array}{l}\text { Belém do São } \\
\text { Francisco }\end{array}$ & US & Federal & 290,93 & $\begin{array}{l}\text { Portaria IBAMA } \\
\mathrm{n}=35 / 2007\end{array}$ \\
\hline RPPN Calaça & Lajedo & US & Federal & 208,63 & $\begin{array}{l}\text { Portaria IBAMA } \\
\text { no } 32 / 2007\end{array}$ \\
\hline
\end{tabular}


Tabela 9. Continuação.

\begin{tabular}{|l|l|l|l|l|l|}
\hline UC & Município & Tipo & Âmbito & Área (ha) & Ato de criação \\
\hline $\begin{array}{l}\text { RPPN Reserva } \\
\text { Umburana }\end{array}$ & $\begin{array}{l}\text { Belém do São } \\
\text { Francisco }\end{array}$ & US & Federal & 131,02 & $\begin{array}{l}\text { Portaria IBAMA } \\
\text { no 34/2007 }\end{array}$ \\
\hline $\begin{array}{l}\text { RPPN Reserva } \\
\text { Cabanos }\end{array}$ & Altinho & US & Federal & 6,00 & $\begin{array}{l}\text { Portaria IBAMA } \\
\text { no 92/2007 }\end{array}$ \\
\hline $\begin{array}{l}\text { RPPN Cantidiano } \\
\text { Valgueiro de } \\
\text { Carvalho Barros }\end{array}$ & Floresta & US & Federal & 285,00 & $\begin{array}{l}\text { Portaria IBAMA } \\
\text { no 177/2002 }\end{array}$ \\
\hline $\begin{array}{l}\text { RPPN Serra do } \\
\text { Contente }\end{array}$ & Floresta & US & Federal & 9,11 & $\begin{array}{l}\text { Portaria ICMBio } \\
\text { no 68/2009 }\end{array}$ \\
\hline Total & - & - & $\mathbf{5 9 0 . 5 7 7 , 6 0}$ & - \\
\hline
\end{tabular}

Fonte: Brasil (2017); IBGE (2019). Legenda: APA = Área de Proteção Ambiental; ARIE = Área de Relevante Interessante Ecológico; ESEC = Estação Ecológica; FLONA = Floresta Nacional; MONA = Monumento Natural; PARNA = Parque Nacional; REBIO = Reserva Biológica; RESEX = Reserva Extrativista; REVIS = Refúgio da Vida Silvestre; RPPN = Reserva Particular do Patrimônio Natural.

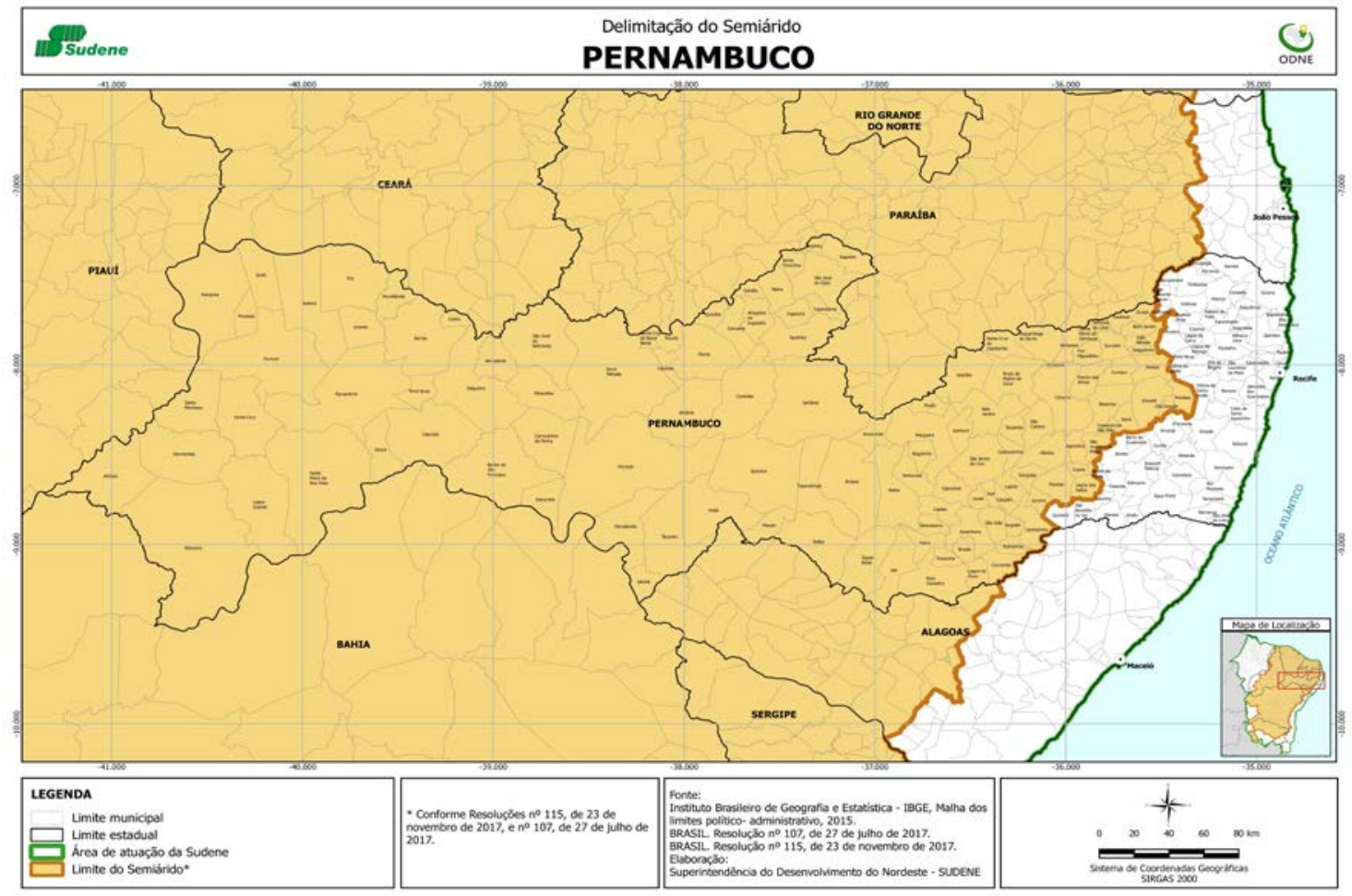

Figura 7. Delimitação da Região Semiárida no Estado de Pernambuco. Fonte: Resolução CONDEL n⿳o 107/2017 (Brasil, 2017), IBGE (2019).

\section{Unidades de conservação na região semiárida do Estado de Alagoas}

O Estado de Alagoas possui 1,11\% (Tabela 3) de sua área atingida pela Região do Semiárido (Figura 8) ocupada por oito unidades de conservação, sendo três de proteção integral e cinco de uso sustentável, das quais duas são administradas pelo governo federal, uma pelo governo estadual e cinco geridas por particulares (Tabela 10). 
O Monumento Natural do Rio São Francisco, criado pelo governo federal, localizado nos Municípios de Delmiro Gouveia, Olho d'Água do Casado e Piranhas, compartilha territórios no Estado de Sergipe e no Estado da Bahia.

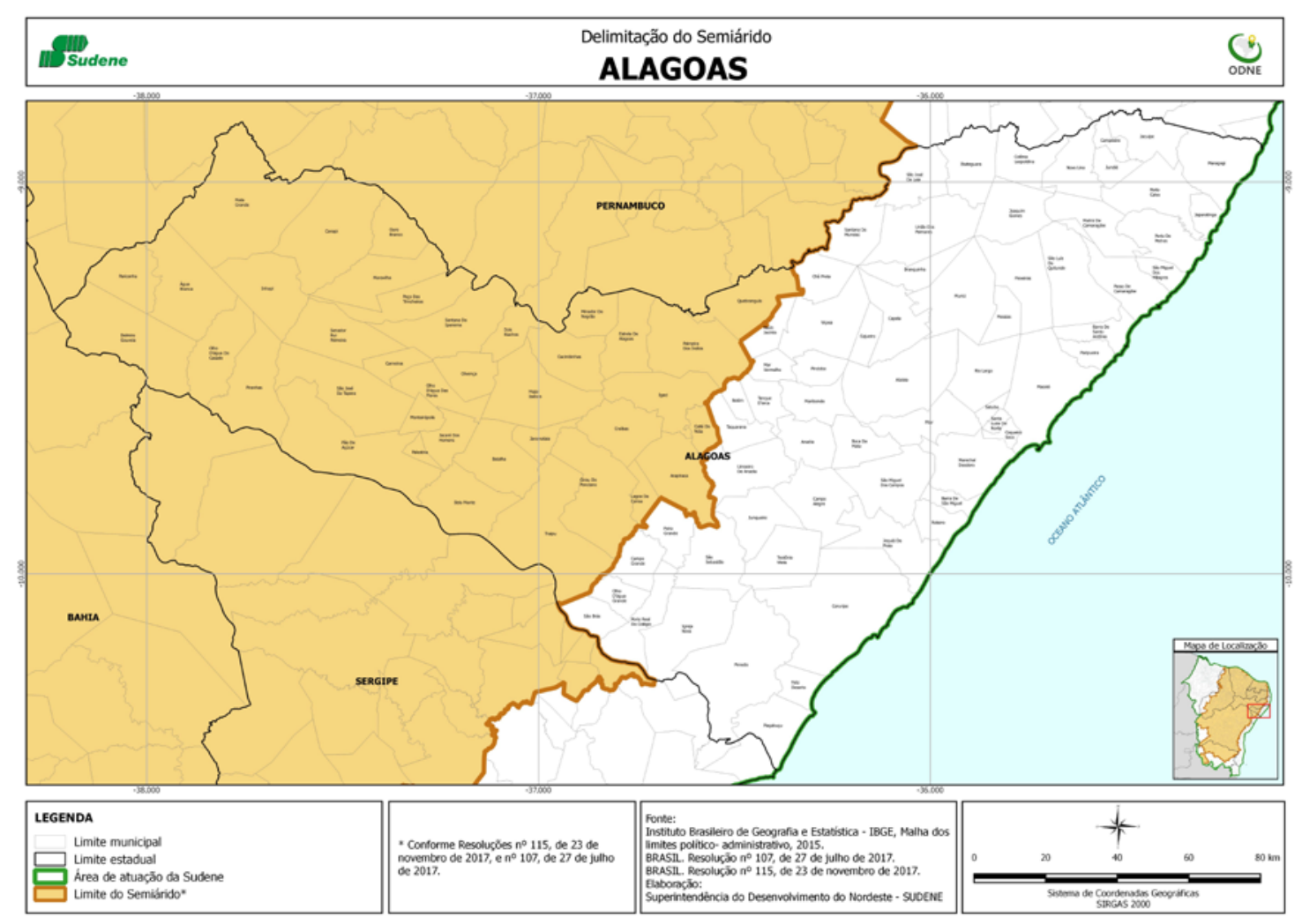

Figura 8. Delimitação da Região Semiárida no Estado de Alagoas. Fonte: Resolução CONDEL no 107/2017 (Brasil, 2017), IBGE (2019).

Tabela 10. Unidade de conservação (UC) na Região Semiárida do Estado de Alagoas.

\begin{tabular}{|c|c|c|c|c|c|}
\hline UC & Município & Tipo & Âmbito & Área (ha) & Ato de criação \\
\hline $\begin{array}{l}\text { REBIO Pedra } \\
\text { Talhada }\end{array}$ & Quebrangulo & PI & Federal & $2.682,00$ & $\begin{array}{ll}\text { Decreto } & \mathrm{n} \text { - } \\
98.524 / 1989\end{array}$ \\
\hline $\begin{array}{l}\text { MONA do Rio } \\
\text { São Francisco }\end{array}$ & $\begin{array}{l}\text { Delmiro Gouveia, Olho } \\
\text { d'Água do Casado e } \\
\text { Piranhas }\end{array}$ & PI & Federal & $26.736,00$ & $\begin{array}{l}\text { Decreto } \\
\text { S/№/2009 }\end{array}$ \\
\hline 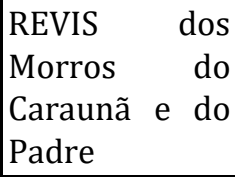 & Água Branca & PI & Estadual & $1.088,00$ & $\begin{array}{ll}\text { Decreto } & \mathrm{n} \text { - } \\
17.935 / 2012 & \end{array}$ \\
\hline $\begin{array}{l}\text { RPPN Jader } \\
\text { Ferreira } \\
\text { Ramos }\end{array}$ & Santana do Ipanema & US & Estadual & 44,00 & \begin{tabular}{|l} 
Portaria \\
$19 / 2008$
\end{tabular} \\
\hline $\begin{array}{l}\text { RPPN José } \\
\text { Abdon Malta } \\
\text { Marques }\end{array}$ & Ouro Branco & US & Estadual & 27,00 & $\begin{array}{l}\text { Portaria } \\
3 / 2009\end{array}$ \\
\hline
\end{tabular}


Tabela 10. Continuação.

\begin{tabular}{|l|l|l|l|l|lr|}
\hline UC & Município & Tipo & Âmbito & Área (ha) & Ato de criação \\
\hline $\begin{array}{l}\text { RPPN Mato da } \\
\text { Onça }\end{array}$ & Pão de Açúcar & US & Estadual & 34,00 & $\begin{array}{l}\text { Portaria } \\
48 / 2015\end{array}$ & $\mathrm{n}^{\mathrm{o}}$ \\
\hline $\begin{array}{l}\text { RPPN } \\
\text { Conceição } \\
\text { Lyra II }\end{array}$ & Penedo & US & Estadual & 348,00 & $\begin{array}{l}\text { Portaria } \\
20 / 2018\end{array}$ & $\mathrm{n}^{\mathrm{o}}$ \\
\hline $\begin{array}{l}\text { RPPN } \\
\begin{array}{l}\text { Conceição } \\
\text { Lyra III }\end{array}\end{array}$ & Maceió & US & Estadual & 852,00 & $\begin{array}{l}\text { Portaria } \\
17 / 2018\end{array}$ \\
\hline Total & - & - & - & $\mathbf{1 3 . 9 8 7 , 0 0}$ & - & \\
\hline
\end{tabular}

Fonte: Brasil (2017); IBGE (2019). Legenda: REBIO = Reserva Biológica. MONA = Monumento Natural. REVIS = Refúgio da Vida Silvestre. RPPN = Reserva Particular do Patrimônio Natural. PI = Proteção Integral. US = Uso Sustentável.

\section{Unidades de conservação na região semiárida do Estado de Sergipe}

O Estado de Sergipe possui 1,03\% (Tabela 3) de sua área atingida pela Região do Semiárido (Figura 9) ocupada por quatro unidades de conservação, sendo três de proteção integral e uma de uso sustentável, das quais uma é administrada pelo governo federal, uma gerida por particulares, uma pelo governo estadual e uma pelo governo municipal (Tabela 11).

O Monumento Natural do Rio São Francisco, criado pelo governo federal, localizado no Município de Canindé de São Francisco, compartilha territórios no Estado de Alagoas e no Estado da Bahia.

Corroborando a hipótese de que as unidades de conservação são importantes espaços protegidos da biodiversidade, inclusive na Região Semiárida, Silva et al. (2016), numa área de 251 ha de Caatinga, localizada no Monumento Natural Grota do Angico, coletaram 1.854 indivíduos, pertencentes a 31 espécies e 17 famílias florestais.

Tabela 11. Unidades de conservação (UC) na região semiárida do Estado de Sergipe.

\begin{tabular}{|l|l|l|l|l|ll|}
\hline UC & Município & Tipo & Âmbito & Área (ha) & Ato de criação \\
\hline $\begin{array}{l}\text { MONA do Rio São } \\
\text { Francisco }\end{array}$ & $\begin{array}{l}\text { Canindé de São } \\
\text { Francisco }\end{array}$ & PI & Federal & $8.912,00$ & $\begin{array}{l}\text { Decreto } \\
\text { S/No/2009 }\end{array}$ \\
\hline $\begin{array}{l}\text { MONA Grota do } \\
\text { Angico }\end{array}$ & Poço Redondo & PI & Estadual & $2.138,00$ & $\begin{array}{l}\text { Decreto } \\
24.922 / 2007\end{array}$ \\
\hline $\begin{array}{l}\text { Parque Natural } \\
\text { Municipal Lagoa } \\
\text { do Frio }\end{array}$ & $\begin{array}{l}\text { Canindé do São } \\
\text { Francisco }\end{array}$ & PI & Municipal & 278,99 & $\begin{array}{l}\text { Decreto } \\
41 / 2001 \quad \text { no }\end{array}$ \\
\hline $\begin{array}{l}\text { RPPN Campos } \\
\text { Novos }\end{array}$ & Carira & US & Federal & 102,77 & $\begin{array}{l}\text { Portaria ICMBio } \\
\text { no 3/2014 }\end{array}$ \\
\hline Total & - & - & - & $\mathbf{1 1 . 4 3 1 , 7 6}$ & - & \\
\hline
\end{tabular}

Fonte: Brasil (2017); IBGE (2019). Legenda: MONA = Monomento Natural; RPPN = Reserva Particular do Patrimônio Natural; PI = Proteção integral; US = Uso Sustentável. 


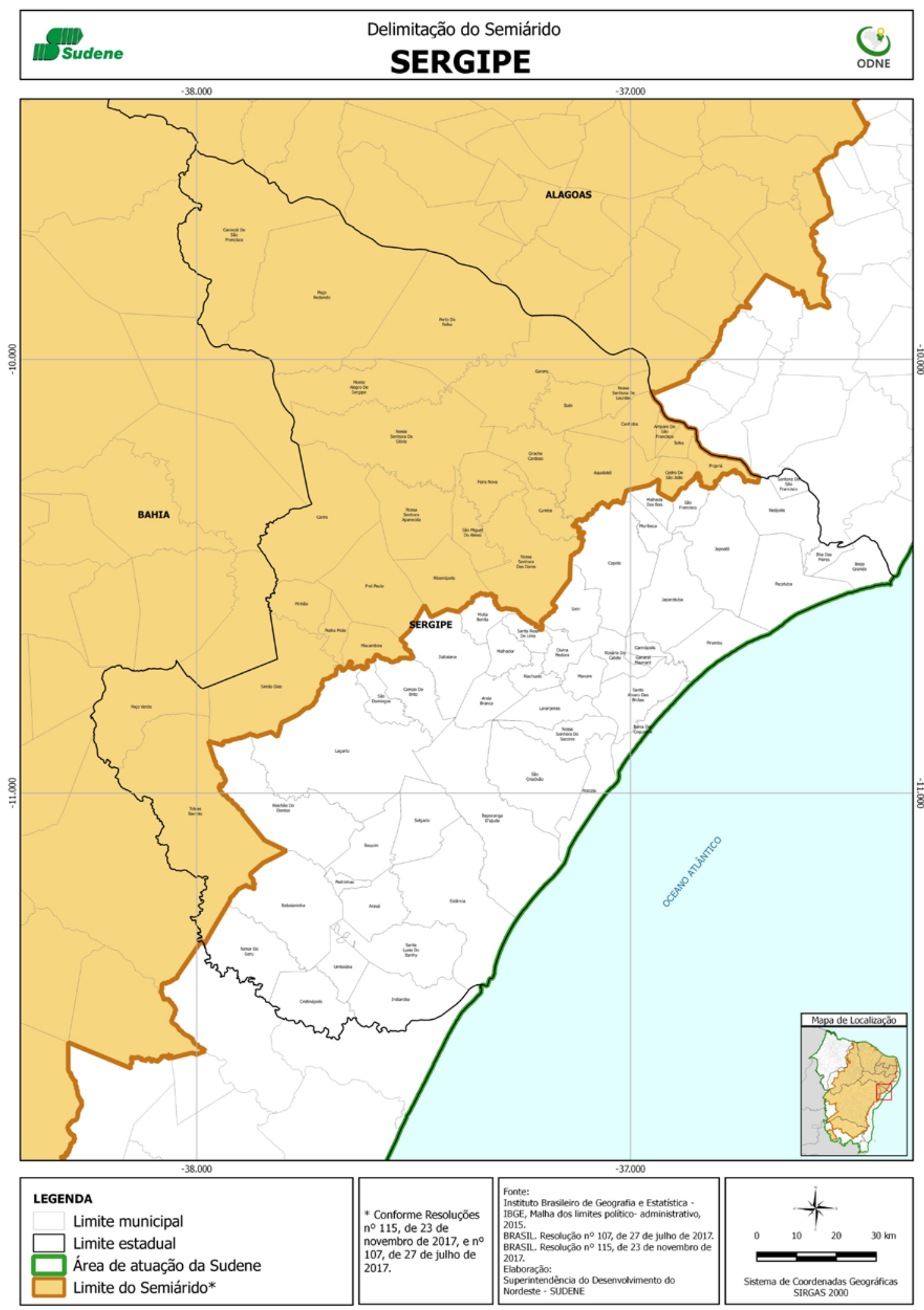

Figura 9. Delimitação da Região Semiárida no Estado de Sergipe. Fonte: Resolução CONDEL noㅜ 107/2017 (Brasil, 2017), IBGE (2019). 


\section{Unidades de conservação na região semiárida do Estado da Bahia}

O Estado da Bahia possui 6,55\% (Tabela 3) de sua área atingida pela Região do Semiárido (Figura 10) ocupada por 71 unidades de conservação, sendo 13 de proteção integral e 58 de uso sustentável, das quais oito são administradas pelo governo federal, 43 gerida por particulares, 16 pelo governo estadual e quatro pelos governos municipais (Tabela 12).

O Monumento Natural do Rio São Francisco, criado pelo governo federal, localizado no Município de Canindé de São Francisco, compartilha territórios no Estado de Alagoas e no Estado de Sergipe.

Tabela 12. Unidades de conservação (UC) na região semiárida do Estado da Bahia.

\begin{tabular}{|c|c|c|c|c|c|}
\hline UC & Município & Tipo & Âmbito & Área (ha) & Ato de criação \\
\hline $\begin{array}{l}\text { ESEC Raso da } \\
\text { Catarina }\end{array}$ & $\begin{array}{l}\text { Rodelas, Paulo Afonso e } \\
\text { Jeremoabo }\end{array}$ & PI & Federal & $104.849,00$ & $\begin{array}{l}\text { Decreto } \quad \mathrm{n} \text { - } \\
89.268 / 1984 \\
\text { Portaria IBAMA } \\
\text { no 373/2001 }\end{array}$ \\
\hline $\begin{array}{l}\text { PARNA } \\
\text { Chapada } \\
\text { Diamantina }\end{array}$ & $\begin{array}{l}\text { Andaraí, Ibicoara, Itaetê, } \\
\text { Lençóis, Mucugê e } \\
\text { Palmeiras }\end{array}$ & PI & Federal & $152.142,00$ & $\begin{array}{ll}\text { Decreto } & \mathrm{n}^{\mathrm{o}} \\
91.655 / 1985\end{array}$ \\
\hline $\begin{array}{l}\text { PARNA } \\
\text { Boqueirão da } \\
\text { Onça }\end{array}$ & \begin{tabular}{|lrr} 
Sento Sé, & Juazeiro, \\
Sobradinho & e & Campo \\
Formoso & & \\
\end{tabular} & PI & Federal & $346.909,00$ & \begin{tabular}{|lr} 
Decreto & $\mathrm{n}^{\mathrm{o}}$ \\
$9.336 / 2018$ &
\end{tabular} \\
\hline $\begin{array}{l}\text { MONA do Rio } \\
\text { São Francisco }\end{array}$ & Paulo Afonso & PI & Federal & $8.912,00$ & \begin{tabular}{|l} 
Decreto \\
S/№/2009
\end{tabular} \\
\hline $\begin{array}{l}\text { APA } \\
\text { Boqueirão da } \\
\text { Onça }\end{array}$ & $\begin{array}{l}\text { Sento Sé, Juazeiro, } \\
\text { Sobradinho, Campo } \\
\text { Formoso, Umburanas e } \\
\text { Morro do Chapéu }\end{array}$ & US & Federal & $505.677,00$ & \begin{tabular}{|l} 
Decreto \\
$9.337 / 2018$
\end{tabular} \\
\hline $\begin{array}{l}\text { FLONA } \\
\text { Contendas do } \\
\text { Sincorá }\end{array}$ & $\begin{array}{l}\text { Contendas do Sincorá e } \\
\text { Tanhaçu }\end{array}$ & US & Federal & $11.216,00$ & $\begin{array}{l}\text { Decreto } \\
\text { S/№/1999 }\end{array}$ \\
\hline $\begin{array}{lr}\text { APA } & \text { da } \\
\text { Ararinha Azul }\end{array}$ & Curaçá e Juazeiro & US & Federal & $90.641,00$ & \begin{tabular}{|l} 
Decreto \\
$9.402 / 2018$
\end{tabular} \\
\hline $\begin{array}{l}\text { ARIE } \\
\text { Cocorobó }\end{array}$ & Jeremoabo & US & Federal & $7.500,00$ & $\begin{array}{ll}\text { Resolução } & \\
\text { CONAMA } & \mathrm{n}^{\circ} \\
5 / 1984 & \\
\end{array}$ \\
\hline $\begin{array}{l}\text { MONA } \\
\text { Cachoeira do } \\
\text { Ferro Doido }\end{array}$ & Morro do Chapéu & PI & Estadual & 400,00 & \begin{tabular}{|lr} 
Decreto & $\mathrm{n}^{\circ}$ \\
$7.412 / 1998$ &
\end{tabular} \\
\hline $\begin{array}{ll}\text { Parque } & \\
\text { Estadual } \\
\text { Morro do } \\
\text { Chapéu }\end{array}$ & Morro do Chapéu & PI & Estadual & $46.000,00$ & \begin{tabular}{|l} 
Decreto \\
$7.413 / 1998$
\end{tabular} \\
\hline $\begin{array}{lr}\text { Parque } & \\
\text { Estadual } & \mathrm{da} \\
\text { Serra } & \mathrm{dos} \\
\text { Montes } & \text { Altos }\end{array}$ & Morro do Chapéu & PI & Estadual & $18.484,00$ & $\begin{array}{l}\text { Decreto } \\
12.486 / 2010\end{array}$ \\
\hline
\end{tabular}


Tabela 12. Continuação.

\begin{tabular}{|c|c|c|c|c|c|}
\hline UC & Município & Tipo & Âmbito & Área (ha) & Ato de criação \\
\hline $\begin{array}{l}\text { Parque } \\
\text { Estadual Sete } \\
\text { Passagens }\end{array}$ & Miguel Calmon & PI & Estadual & $2.822,00$ & $\begin{array}{ll}\text { Decreto } & \mathrm{n}^{\mathbf{o}} \\
7.808 / 2000 & \end{array}$ \\
\hline $\begin{array}{l}\text { REVIS da } \\
\text { Ararinha Azul }\end{array}$ & Curaçá e Juazeiro & PI & Estadual & $29.234,00$ & \begin{tabular}{|l} 
Decreto \\
$9.402 / 2018$
\end{tabular} \\
\hline $\begin{array}{lr}\text { REVIS da } \\
\text { Serra dos } \\
\text { Montes Altos }\end{array}$ & 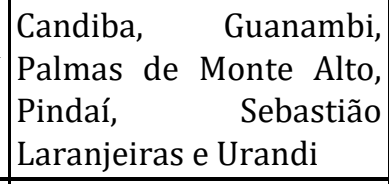 & PI & Estadual & $27.499,00$ & $\begin{array}{l}\text { Decreto } \quad \mathrm{n}^{\mathrm{o}} \\
12.487 / 2010\end{array}$ \\
\hline $\begin{array}{l}\text { APA Dunas e } \\
\text { Veredas do } \\
\text { Baixo Médio } \\
\text { São Francisco }\end{array}$ & $\begin{array}{l}\text { Barra, Pilão Arcado e } \\
\text { Xique Xique }\end{array}$ & US & Estadual & $1.085 .000,00$ & $\begin{array}{l}\text { Decreto } \\
6.547 / 1997\end{array}$ \\
\hline $\begin{array}{l}\text { APA Gruta dos } \\
\text { Brejões } \\
\text { Vereda do } \\
\text { Romão } \\
\text { Gramacho }\end{array}$ & $\begin{array}{l}\text { João Dourado, Morro do } \\
\text { Chapéu e São Gabriel }\end{array}$ & US & Estadual & $11.900,00$ & $\begin{array}{l}\text { Decreto } \quad \mathrm{n}^{\mathrm{o}} \\
32.487 / 1985\end{array}$ \\
\hline $\begin{array}{lr}\text { APA Lago de } \\
\text { Pedra } & \text { do } \\
\text { Cavalo } & \\
\end{array}$ & $\begin{array}{llr}\text { Feira de } & \text { Santana, } \\
\text { Antônio } & \text { Cardoso, Santo } \\
\text { Estevão, } & \text { Cabaceiras do } \\
\text { Paraguaçu, } & \text { Governador } \\
\text { Mangabeira, } & \text { Muritiba, } \\
\text { São Felix, Cachoeira, } & \text { Cacira São } \\
\text { Conceição da Feira e Salo } & \text { Gonçalo dos Campos } \\
\end{array}$ & US & Estadual & $30.156,00$ & $\begin{array}{l}\text { Decreto } \\
6.548 / 1997\end{array}$ \\
\hline $\begin{array}{l}\text { APA Lago do } \\
\text { Sobradinho }\end{array}$ & $\begin{array}{l}\text { Casa Nova, Remanso, } \\
\text { Pilão Arcado, Sento Sé e } \\
\text { Sobradinho }\end{array}$ & US & Estadual & $1.237,374$ & $\begin{array}{l}\text { Decreto } \\
9.957 / 2006\end{array}$ \\
\hline $\begin{array}{l}\text { APA Lagoa de } \\
\text { Itaparica }\end{array}$ & $\begin{array}{l}\text { Xique Xique e Gentio do } \\
\text { Ouro }\end{array}$ & US & Estadual & $78.450,00$ & \begin{tabular}{|l} 
Decreto \\
$6.546 / 1997$
\end{tabular} \\
\hline $\begin{array}{l}\text { APA } \\
\text { Marimbus/Ira } \\
\text { quara }\end{array}$ & $\begin{array}{l}\text { Lençóis, Palmeiras, } \\
\text { Iraquara e Seabra }\end{array}$ & US & Estadual & $125.400,00$ & $\begin{array}{l}\text { Decreto } \\
2.216 / 1993\end{array}$ \\
\hline $\begin{array}{l}\text { APA Serra } \\
\text { Branca/Raso } \\
\text { da Catarina }\end{array}$ & Jeremoabo & US & Estadual & $67.234,00$ & $\begin{array}{l}\text { Decreto } \\
7.972 / 2001\end{array}$ \\
\hline $\begin{array}{l}\text { APA Serra do } \\
\text { Barbado }\end{array}$ & $\begin{array}{l}\text { Abaíra, Érico Cardoso, } \\
\text { Jussiape, Piatã, Rio de } \\
\text { Contas e Rio de Pires }\end{array}$ & US & Estadual & $63.652,00$ & $\begin{array}{l}\text { Decreto } \\
2.183 / 1993\end{array}$ \\
\hline $\begin{array}{l}\text { ARIE } \\
\text { Nascentes do } \\
\text { Rio De Contas }\end{array}$ & Abaíra e Piatã & US & Estadual & $4.765,00$ & $\begin{array}{l}\text { Decreto } \\
7.968 / 2001\end{array}$ \\
\hline $\begin{array}{l}\text { ARIE Serra de } \\
\text { Orobó }\end{array}$ & Rui Barbosa e Itaberaba & US & Estadual & $7.397,00$ & $\begin{array}{ll}\text { Decreto } & \mathrm{n} \text { - } \\
8.267 / 2002 & \end{array}$ \\
\hline
\end{tabular}

Rev. Bras. Gest. Amb. Sustent., 2020, vol. 7, n. 17, p. 1283-1334. 
Tabela 12. Continuação.

\begin{tabular}{|c|c|c|c|c|c|}
\hline UC & Município & Tipo & Âmbito & Área (ha) & Ato de criação \\
\hline $\begin{array}{|ll|}\text { Reserva } & \\
\text { Ecológica } & \text { e } \\
\text { Arqueológica } \\
\text { Serra } & \text { do } \\
\text { Mulato } & \end{array}$ & Juazeiro & PI & Municipal & $39.555,00$ & \begin{tabular}{|lr} 
Decreto & $\mathrm{n}$ o \\
$12 / 1997$ &
\end{tabular} \\
\hline \begin{tabular}{|l} 
Parque \\
Natural \\
Municipal de \\
Andaraí rota \\
das \\
Cachoeiras
\end{tabular} & Andaraí & PI & Municipal & $9.311,00$ & Lei no $175 / 2016$ \\
\hline \begin{tabular}{|l|} 
Parque \\
Natural \\
Municipal da \\
Macaqueiras
\end{tabular} & Jacobina & PI & Municipal & 119,00 & \begin{tabular}{|lr} 
Lei no 651/2003 \\
Lei & no \\
$1.469 / 2017$ &
\end{tabular} \\
\hline $\begin{array}{|ll|}\text { APA } & \text { Broto } \\
\text { d'Água } & \end{array}$ & Boquira & US & Municipal & 570,00 & Lei no $168 / 1993$ \\
\hline $\begin{array}{l}\text { RPPN Pico do } \\
\text { Barbado }\end{array}$ & Abaíra & US & Federal & 287,04 & $\begin{array}{l}\text { Portaria ICMBio } \\
\text { no } 76 / 2010\end{array}$ \\
\hline \begin{tabular}{ll|} 
RPPN \\
Fazenda Boa \\
Aventura
\end{tabular} & Barra & US & Federal & $4.750,00$ & $\begin{array}{l}\text { Portaria IBAMA } \\
\text { no } 63 / 2000\end{array}$ \\
\hline $\begin{array}{l}\text { RPPN Rio dos } \\
\text { Monos }\end{array}$ & Barra do Choça & US & Federal & 8,85 & \begin{tabular}{|l}
$\begin{array}{l}\text { Portaria ICMBio } \\
\text { no 19/2006 }\end{array}$ \\
\end{tabular} \\
\hline RPPN Guará & Cocos & US & Federal & $1.050,00$ & $\begin{array}{l}\text { Portaria IBAMA } \\
\text { no } 101 / 2001\end{array}$ \\
\hline \begin{tabular}{|l|} 
RPPN Guará I \\
e II
\end{tabular} & Cocos & US & Federal & 633,00 & \begin{tabular}{|l}
$\begin{array}{l}\text { Portaria IBAMA } \\
\text { no 102/2001 }\end{array}$ \\
\end{tabular} \\
\hline $\begin{array}{l}\text { RPPN Lagoa } \\
\text { do Formoso }\end{array}$ & Cocos & US & Federal & 502,00 & $\begin{array}{l}\text { Portaria IBAMA } \\
\text { no } 115 / 2001\end{array}$ \\
\hline $\begin{array}{l}\text { RPPN Reserva } \\
\text { Itaguari }\end{array}$ & Cocos & US & Federal & $4.000,00$ & $\begin{array}{l}\text { Portaria IBAMA } \\
\text { no } 128 / 2002\end{array}$ \\
\hline $\begin{array}{lr}\text { RPPN } & \text { São } \\
\text { Francisco } & \text { da } \\
\text { Trijunção } & \end{array}$ & Cocos & US & Federal & 162,00 & $\begin{array}{l}\text { Portaria IBAMA } \\
\text { no 112/2001 }\end{array}$ \\
\hline $\begin{array}{|lr|}\text { RPPN } & \text { Pedra } \\
\text { do } & \text { São José II } \\
\end{array}$ & Esplanada & US & Federal & 232,23 & \begin{tabular}{|l}
$\begin{array}{l}\text { Portaria ICMBio } \\
\text { no } 1.006 / 2018\end{array}$ \\
\end{tabular} \\
\hline \begin{tabular}{|l|} 
RPPN \\
Cajueiro
\end{tabular} & Esplanada & US & Federal & 379,00 & $\begin{array}{l}\text { Portaria IBAMA } \\
\text { no 136/2002 }\end{array}$ \\
\hline \begin{tabular}{|l|} 
RPPN \\
Fazenda Pé de \\
Serra
\end{tabular} & Ibotirama & US & Federal & $1.259,00$ & $\begin{array}{l}\text { Portaria IBAMA } \\
\text { no 60-N/1992 }\end{array}$ \\
\hline \begin{tabular}{|l|} 
RPPN \\
Fazenda Forte \\
\end{tabular} & Malhada & US & Federal & $1.500,00$ & \begin{tabular}{|l} 
Portaria IBAMA \\
no 132-N/1997 \\
\end{tabular} \\
\hline $\begin{array}{l}\text { RPPN } \\
\text { Fazenda Forte }\end{array}$ & Malhada & US & Federal & $1.800,00$ & $\begin{array}{l}\text { Portaria IBAMA } \\
\text { no 9-N/1998 }\end{array}$ \\
\hline
\end{tabular}


Tabela 12. Continuação.

\begin{tabular}{|c|c|c|c|c|c|}
\hline $\mathrm{UC}$ & Município & Tipo & Âmbito & Área (ha) & Ato de criação \\
\hline $\begin{array}{l}\text { RPPN } \\
\text { Fazenda } \\
\text { Retiro }\end{array}$ & Malhada & US & Federal & $3.000,00$ & $\begin{array}{l}\text { Portaria IBAMA } \\
\text { no } 49-\mathrm{N} / 1998\end{array}$ \\
\hline $\begin{array}{|ll|}\text { RPPN } & \\
\text { Fazenda } & \text { Boa } \\
\text { Vista } & \\
\end{array}$ & Malhada & US & Federal & $1.500,00$ & $\begin{array}{l}\text { Portaria IBAMA } \\
\text { no } 133-\mathrm{N} / 1997\end{array}$ \\
\hline \begin{tabular}{|l|} 
RPPN \\
Fazenda Boa \\
Vista
\end{tabular} & Malhada & US & Federal & $1.700,00$ & $\begin{array}{l}\text { Portaria IBAMA } \\
\text { no } 88-\mathrm{N} / 1998\end{array}$ \\
\hline $\begin{array}{ll}\text { RPPN } & \\
\text { Fazenda Boa } \\
\text { Vista }\end{array}$ & Malhada & US & Federal & $2.000,00$ & $\begin{array}{l}\text { Portaria IBAMA } \\
\text { no 134/1997 }\end{array}$ \\
\hline $\begin{array}{l}\text { RPPN Adilia } \\
\text { Paraguaçu } \\
\text { Batista }\end{array}$ & Mucugê & US & Federal & 70,00 & $\begin{array}{l}\text { Portaria IBAMA } \\
\text { no } 88 / 2002\end{array}$ \\
\hline \begin{tabular}{|l|} 
RPPN \\
Fazenda \\
Lagoa das \\
Campinas \\
\end{tabular} & Palma de Monte Alto & US & Federal & $1.000,00$ & $\begin{array}{l}\text { Portaria IBAMA } \\
\text { no } 52-\mathrm{N} / 1998\end{array}$ \\
\hline $\begin{array}{l}\text { RPPN Córrego } \\
\text { dos Bois }\end{array}$ & Palmeiras & US & Federal & 50,00 & $\begin{array}{l}\text { Portaria IBAMA } \\
\text { no 53/2000 }\end{array}$ \\
\hline $\begin{array}{l}\text { RPPN Canto } \\
\text { dos Pássaros }\end{array}$ & Queimadas & US & Federal & 215,00 & $\begin{array}{l}\text { Portaria ICMBio } \\
\text { no 23/2011 }\end{array}$ \\
\hline $\begin{array}{l}\text { RPPN } \\
\text { Fazenda } \\
\text { Morrinhos }\end{array}$ & Queimadas & US & Federal & 299,00 & $\begin{array}{l}\text { Portaria IBAMA } \\
\text { no 644/1990 } \\
\text { Portaria IBAMA } \\
\text { no } 71 / 2006\end{array}$ \\
\hline \begin{tabular}{|l} 
RPPN \\
Fazenda \\
Piabas \\
\end{tabular} & Queimadas & US & Federal & 110,00 & $\begin{array}{l}\text { Portaria IBAMA } \\
\text { no } 62 / 2000\end{array}$ \\
\hline \begin{tabular}{ll|} 
RPPN & \\
Fazenda & Flor \\
de Liz & \\
\end{tabular} & Ribeira do Pombal & US & Federal & 5,00 & $\begin{array}{l}\text { Portaria IBAMA } \\
\text { no 121-N/1996 }\end{array}$ \\
\hline $\begin{array}{l}\text { RPPN Volta do } \\
\text { Rio }\end{array}$ & Rio de Contas & US & Federal & 102,00 & $\begin{array}{l}\text { Portaria ICMBio } \\
\text { no } 37 / 2014\end{array}$ \\
\hline $\begin{array}{lr}\text { RPPN } & \text { Serra } \\
\text { das } & \text { Almas de } \\
\text { Rio de Contas }\end{array}$ & Rio de Contas & US & Federal & 263,00 & $\begin{array}{l}\text { Portaria ICMBio } \\
\text { no } 72 / 2014\end{array}$ \\
\hline 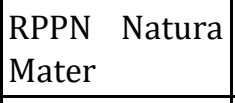 & Rio de Contas & US & Federal & 41,00 & \begin{tabular}{|l} 
Portaria ICMBio \\
n- 24/2014
\end{tabular} \\
\hline $\begin{array}{l}\text { RPPN } \\
\text { Brumadinho }\end{array}$ & Rio de Contas & US & Federal & 12,08 & \begin{tabular}{|l|} 
Portaria ICMBio \\
no 19/2014 \\
\end{tabular} \\
\hline $\begin{array}{ll}\text { RPPN } & \text { Ave } \\
\text { Natura } & \end{array}$ & Rio de Contas & US & Federal & 44,14 & $\begin{array}{l}\text { Portaria ICMBio } \\
\text { no } 71 / 2014\end{array}$ \\
\hline $\begin{array}{l}\text { RPPN Natura } \\
\text { Cerrada }\end{array}$ & Rio de Contas & US & Federal & 91,07 & $\begin{array}{l}\text { Portaria ICMBio } \\
\text { no } 22 / 2014\end{array}$ \\
\hline
\end{tabular}


Tabela 12. Continuação.

\begin{tabular}{|c|c|c|c|c|c|}
\hline UC & Município & Tipo & Âmbito & Área (ha) & Ato de criação \\
\hline $\begin{array}{l}\text { RPPN Reserva } \\
\text { Caroá }\end{array}$ & Santana & US & Federal & 220,00 & $\begin{array}{l}\text { Portaria IBAMA } \\
\mathrm{n} \text { - } 110 / 2001\end{array}$ \\
\hline $\begin{array}{ll}\text { RPPN } & \text { Maria } \\
\text { Maria } & \\
\end{array}$ & Saúde & US & Federal & 4,11 & $\begin{array}{l}\text { Portaria ICMBio } \\
\text { no } 255 / 2013\end{array}$ \\
\hline $\begin{array}{l}\text { RPPN } \\
\text { Fazenda } \\
\text { Kaybí }\end{array}$ & Ubaíra & US & Federal & 5,00 & $\begin{array}{l}\text { Portaria IBAMA } \\
\text { no } 117-\mathrm{N} / 1994\end{array}$ \\
\hline $\begin{array}{l}\text { RPPN } \\
\text { Itamarandiba }\end{array}$ & Abaíra & US & Federal & 287,00 & $\begin{array}{l}\text { Portaria ICMBio } \\
\text { no } 76 / 2010\end{array}$ \\
\hline $\begin{array}{l}\text { RPPN Reserva } \\
\text { Pouso das } \\
\text { Garças }\end{array}$ & Ribeira do Pombal & US & Federal & 5,00 & $\begin{array}{l}\text { Portaria IBAMA } \\
\text { no } 121-\mathrm{N} / 1996\end{array}$ \\
\hline $\begin{array}{l}\text { RPPN Toca } \\
\text { dos Ossos }\end{array}$ & Ourolândia & US & Estadual & 20,00 & $\begin{array}{ll}\text { Portaria } & n^{\circ} \\
13.203 / 2016 & \end{array}$ \\
\hline $\begin{array}{l}\text { RPPN Reserva } \\
\text { Recanto dos } \\
\text { Pássaros }\end{array}$ & Jacobina & US & Estadual & 9,00 & $\begin{array}{ll}\text { Portaria } & \mathrm{n}^{\mathrm{o}} \\
17.381 / 2018 & \end{array}$ \\
\hline $\begin{array}{l}\text { RPPN Reserva } \\
\text { Candeal do } \\
\text { Vale }\end{array}$ & Jacobina & US & Estadual & 6,00 & $\begin{array}{ll}\text { Portaria } & \mathrm{n}^{\mathrm{o}} \\
17.382 / 2018 & \end{array}$ \\
\hline $\begin{array}{l}\text { RPPN Reserva } \\
\text { Serra do Luar }\end{array}$ & Caém e Jacobina & US & Estadual & 9,00 & $\begin{array}{ll}\text { Portaria } & n^{\circ} \\
17.383 / 2018 & \\
\end{array}$ \\
\hline $\begin{array}{l}\text { RPPN Reserva } \\
\text { Lendas do } \\
\text { Coió }\end{array}$ & Jacobina & US & Estadual & 27,00 & $\begin{array}{l}\text { Portaria } \quad n^{\circ} \\
17.384 / 2018\end{array}$ \\
\hline $\begin{array}{lr}\text { RPPN } & \text { Reserva } \\
\text { Terra } & \text { Que } \\
\text { Brilha } & \end{array}$ & Jacobina & US & Estadual & 2,00 & $\begin{array}{ll}\text { Portaria } & \mathrm{n}^{\mathrm{o}} \\
17.385 / 2018 & \end{array}$ \\
\hline $\begin{array}{l}\text { RPPN Reserva } \\
\text { Casa do Sol }\end{array}$ & Jacobina & US & Estadual & 3,00 & $\begin{array}{ll}\text { Portaria } & \mathrm{n}^{\mathrm{o}} \\
17.386 / 2018 & \end{array}$ \\
\hline $\begin{array}{l}\text { RPPN Reserva } \\
\text { Ganesha }\end{array}$ & Jacobina & US & Estadual & 2,00 & $\begin{array}{ll}\text { Portaria } & n^{\circ} \\
17.387 / 2018 & \end{array}$ \\
\hline Total & - & - & - & $2.904 .695,89$ & - \\
\hline
\end{tabular}

Fonte: Brasil (2017); IBGE (2019). Legenda: APA = Área de Proteção Ambiental; ARIE = Área de Relevante Interessante Ecológico; $\mathrm{ESEC}=$ Estação Ecológica; FLONA = Floresta Nacional; MONA = Monumento Natural; PARNA = Parque Nacional; REBIO = Reserva Biológica; RESEX = Reserva Extrativista; REVIS = Refúgio da Vida Silvestre; RPPN = Reserva Particular do Patrimônio Natural. PI = Proteção integral; US = Uso Sustentável. 


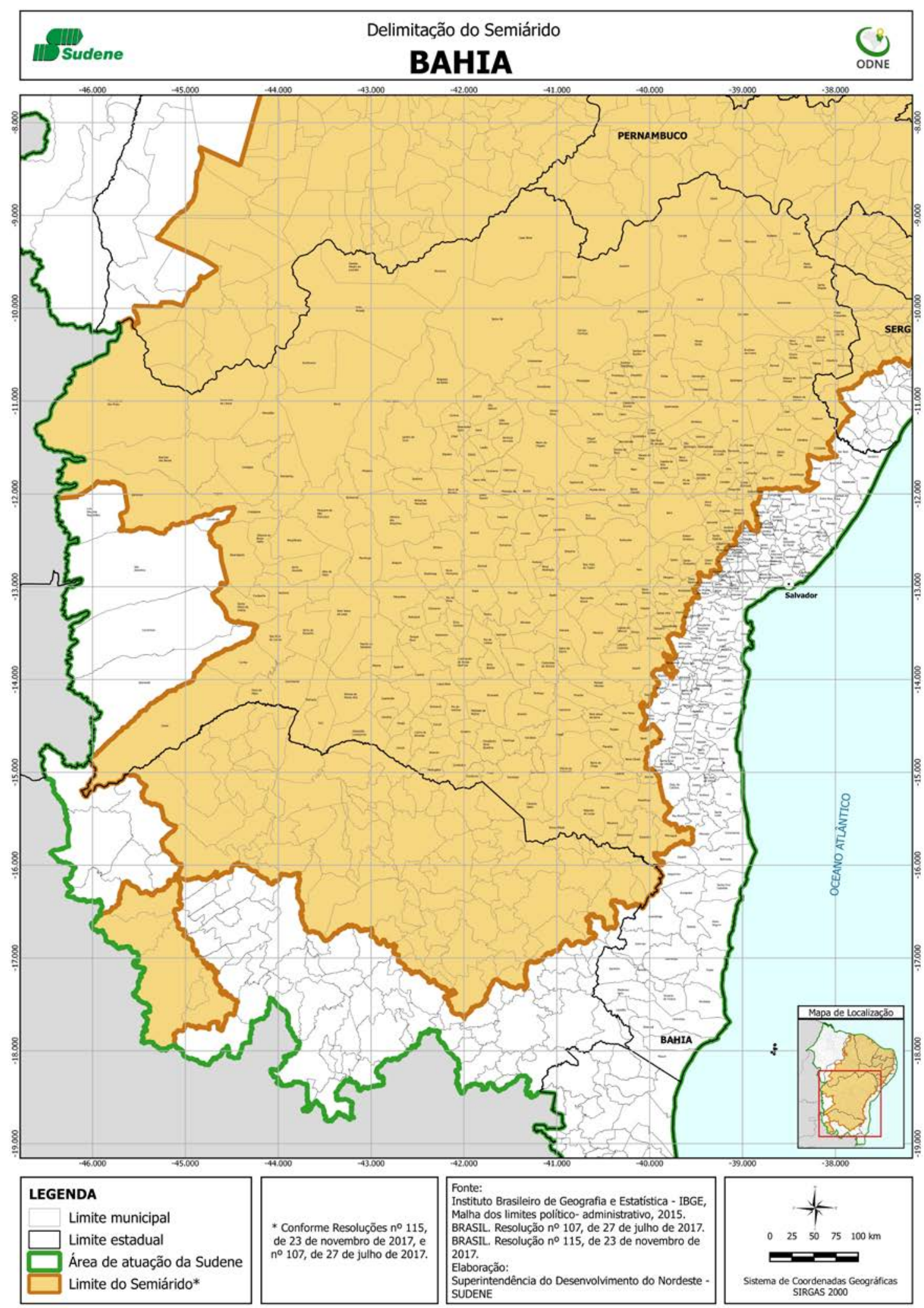

Figura 10. Delimitação da Região Semiárida no Estado da Bahia. Fonte: Resolução CONDEL noㅜ 107/2017 (Brasil, 2017), IBGE (2019). 


\section{Unidades de conservação na região semiárida do Estado de Minas Gerais}

O Estado de Minas Gerais possui 10,70\% (Tabela 3) de sua área atingida pela Região do Semiárido (Figura 11) ocupada por nove unidades de conservação, sendo cinco de proteção integral e quatro de uso sustentável, das quais duas são administradas pelo governo federal, duas geridas por particulares e cinco pelo governo estadual (Tabela 13).

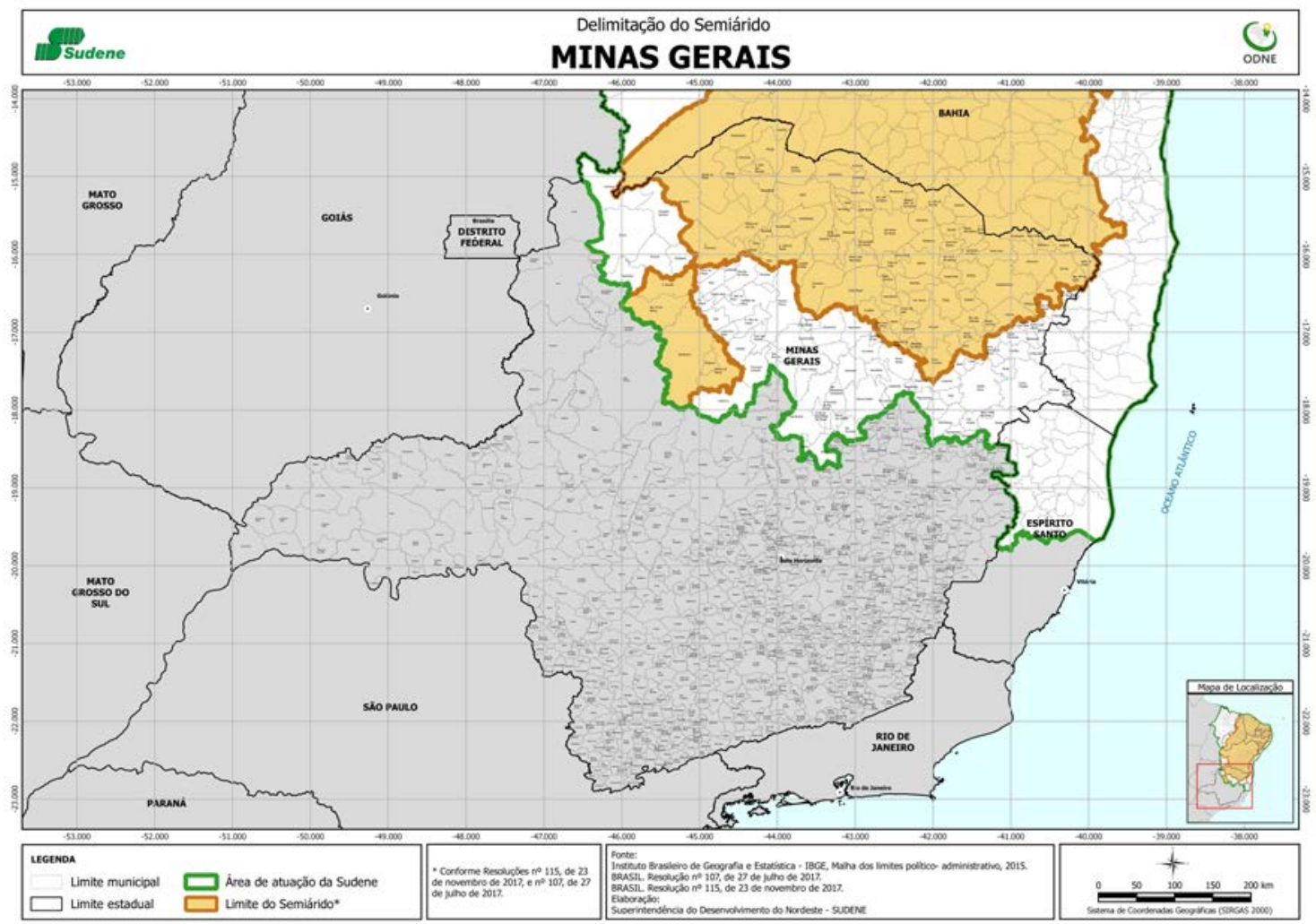

Figura 11. Delimitação da Região Semiárida no Estado de Minas Gerais. Fonte: Resolução CONDEL no 107/2017 (Brasil, 2017), IBGE (2019).

Tabela 13. Unidades de conservação (UC) na região semiárida do Estado de Minas Gerais.

\begin{tabular}{|l|c|c|c|c|l|}
\hline UC & Município & Tipo & Âmbito & Área (ha) & Ato de criação \\
\hline $\begin{array}{l}\text { PARNA Cavernas } \\
\text { do Peruaçu }\end{array}$ & $\begin{array}{c}\text { Itacarambi, Januáia, } \\
\text { São João }\end{array}$ & PI & Federal & $56.800,00$ & $\begin{array}{l}\text { Decreto } \mathrm{no} \\
89.953 / 1998\end{array}$ \\
\hline $\begin{array}{l}\text { APA Cavernas do } \\
\text { Peruaçu }\end{array}$ & $\begin{array}{c}\text { Cônego Marinho, } \\
\text { Itacarambi }\end{array}$ & US & Federal & 90.695 & $\begin{array}{l}\text { Decreto } \mathrm{no} \\
89.953 / 1998\end{array}$ \\
\hline REBIO Jaíba & Matias Cardoso & PI & Estadual & $6.359,00$ & $\begin{array}{l}\text { Lei } \\
6.126 / 1973 \\
\text { Lei } \\
11.731 / 1994\end{array}$ \\
\hline
\end{tabular}


Tabela 13. Continuação.

\begin{tabular}{|l|l|l|l|l|l|}
\hline UC & Município & Tipo & Âmbito & Área (ha) & Ato de criação \\
\hline $\begin{array}{l}\text { Parque Estadual } \\
\text { Verde Grande }\end{array}$ & Matias Cardoso & PI & Estadual & $25.570,00$ & $\begin{array}{l}\text { Decreto } \\
89.953 / 1998\end{array}$ \\
\hline $\begin{array}{l}\text { Parque Estadual } \\
\text { Mata Seca }\end{array}$ & Manga & PI & Estadual & $15.119,00$ & $\begin{array}{l}\text { Decreto no } \\
41.479 / 1998\end{array}$ \\
\hline $\begin{array}{l}\text { Parque Estadual } \\
\text { Lagoa do } \\
\text { Cajueiro }\end{array}$ & Matias Cardoso & PI & Estadual & 20.500 & $\begin{array}{l}\text { Decreto } \\
39.954 / 1998 ~\end{array}$ \\
\hline APA Lajedão & Matias Cardoso & US & Estadual & 12.000 & $\begin{array}{l}\text { Decreto } \\
39.951 / 1998\end{array}$ \\
\hline $\begin{array}{l}\text { RPPN Mata do } \\
\text { Passarinho }\end{array}$ & Bandeira & US & Federal & 345,80 & $\begin{array}{l}\text { Portaria ICMBio } \\
\text { no 110/2016 }\end{array}$ \\
\hline $\begin{array}{l}\text { RPPN Fazenda } \\
\text { Ressaca }\end{array}$ & Manga & US & Federal & $4.055,00$ & $\begin{array}{l}\text { Portaria } \\
\text { lBAMA } \\
25-N / 1998 ~\end{array}$ \\
\hline Total & - & - & $\mathbf{2 3 1 . 4 4 3 , 8 0}$ & - \\
\hline
\end{tabular}

Fonte: Brasil (2017); IBGE (2019). Legenda: APA = Área de Proteção Ambiental; PARNA = Parque Nacional; REBIO = Reserva Biológica; RPPN = Reserva Particular do Patrimônio Natural. PI = Proteção integral; US = Uso Sustentável.

A Tabela 14 apresenta um quantitativo de unidades de conservação criadas na Região Semiárida do Brasil.

Tabela 14. Quantidade de unidades de conservação (UC) na região semiárida do Brasil, por unidade da federação.

\begin{tabular}{|l|c|c|c|c|l|c|c|}
\hline & PI & US & FED & EST & MUN & RPPN & Total \\
\hline Maranhão & - & 4 & 1 & 2 & - & 1 & 4 \\
\hline Piauí & 4 & 14 & 8 & 4 & - & 6 & 18 \\
\hline Ceará & 21 & 65 & 11 & 25 & 10 & 40 & 86 \\
\hline Rio Grande do Norte & 3 & 6 & 3 & 2 & - & 4 & 9 \\
\hline Paraíba & 6 & 12 & - & 9 & 1 & 8 & 18 \\
\hline Pernambuco & 14 & 11 & 4 & 10 & 2 & 9 & 25 \\
\hline Alagoas & 3 & 5 & 2 & 1 & - & 5 & 8 \\
\hline Sergipe & 3 & 1 & 1 & 1 & 1 & 1 & 4 \\
\hline Bahia & 13 & 58 & 8 & 16 & 4 & 43 & 71 \\
\hline Minas Gerais & 5 & 4 & 2 & 5 & - & 2 & 14 \\
\hline Total & $\mathbf{7 2}$ & $\mathbf{1 8 0}$ & $\mathbf{4 0}$ & $\mathbf{7 5}$ & $\mathbf{1 8}$ & $\mathbf{1 1 9}$ & $\mathbf{2 5 2}$ \\
\hline
\end{tabular}

Legenda: PI = Proteção integral; US = Uso Sustentável. FED = Federal. EST = Estadual. MUN = Municipal. RPPN = Reserva Particular do Patrimônio Natural.

A principal motivação para a criação de unidades de conservação é a conservação da biodiversidade, entretanto a preservação dos atributos ambientais, como as belezas 
cênicas das paisagens também tem sido motivador para a manutenção destas áreas protegidas.

Embora por definição as unidades de conservação sejam áreas protegidas criadas por atos dos poderes executivo federal, estadual e municipal, o Conselho Nacional Meio Ambiente (CONAMA), por vezes, executou este papel. São os casos, por exemplo, da Área de Relevante Interesse Ecológico de Cocorobó, localizada no Município de Jaremoabo, no Estado da Bahia, que foi criada pela Resolução CONAMA no 005/1984 (Brasil, 1984), e a Área de Relevante Interesse Ecológico Vale dos Dinossauros, localizada na Região do Rio do Peixe, nos Municípios de Sousa e Antenor Navarro, no Estado da Paraíba, que foi criada pela Resolução CONAMA no 17/1984 (Brasil, 1984). Embora os respectivos decretos não tenham sido publicados, estas unidades de conservação de uso sustentável foram consideradas criadas.

No caso da ARIE Vale do Dinossauro, ela foi sobreposta pela unidade de proteção integral Monumento Natural Vale dos Dinossauros, criada pelo governo estadual da Paraíba, pelo Decreto no 23.832/2002, que agora responde pela administração da unidade.

Já a Reserva de Vida Silvestre Tatu-Bola, localizada na Mesorregião do São Francisco, no perímetro dos Municípios de Petrolina, Lagoa Grande e Santa Maria da Boa Vista, no Estado de Pernambuco, foi criada após a indicação de Melo et al. (2014) do tatu-bola Tolypeutes tricinctus para ser o mascote da Copa do Mundo da FIFA de 2014 (Lacerda et al., 2017).

A Região Semiárida do Brasil conta atualmente com 252 unidades de conservação, sendo 72 de proteção integral e 180 de uso sustentável (Tabela 14). Destas 252 unidades de conservação, 40 são administradas pelo governo federal, 75 pelos governos estaduais, 18 pelos governos municipais e 119 Reservas Particulares do Patrimônio Natural (RPPN) geridas por particulares, que protege 67.118,07 ha. Embora estas Reservas Particulares do Patrimônio Natural (RPPN) sejam numerosas, efetivamente, protegem apenas 0,06\% da Região Semiárida.

A quantidade de Reservas Particulares do Patrimônio Natural (RPPN) criadas tem aumentado consideravelmente nestes últimos 12 anos. De 14 (Silva, 2008), para 42 (Maciel, 2010) e para 119 no presente estudo. De acordo com Farias (2010), embora a Lei no 9.985/2000 (Brasil, 2000) classifique as RPPN como de uso sustentável, as restrições impostas pela lei do SNUC são tamanhas que na prática estas unidades, averbada perpetuamente na escritura do imóvel, terminam configurando de proteção integral, embora não haja alteração no direito da propriedade.

Não apenas o número de unidades de conservação é importante para proteger a biodiversidade e as belezas cênicas de um determinado território. A proteção efetiva de uma área para a conservação de um bioma, colimando assim os objetivos da Convenção da Diversidade Biológica, da qual o Brasil é signatário, está diretamente relacionada com a área da unidade de conservação. Em termos absolutos, na Região Semiárida do Brasil, o Estado da Bahia é o que mais protege o semiárido, conservando uma área de 2.904.695,89 ha (Tabela 3), distribuídas em 71 unidades de conservação, sendo 13 unidades de proteção integral e 58 de uso sustentável (Tabela 14).

Entretanto, em termos relativos, o Estado do Piauí protege 12,37\% de sua área atingida pela Região Semiárida, com unidades de conservação (Tabela 3), distribuídas em 18 unidades de conservação, sendo quatro de proteção integral e 14 de uso sustentável (Tabela 14).

Graças à aprovação do Sistema Nacional de Unidades de Conservação (SNUC), pela Lei no 9.985/2000, o Brasil detém um instrumento legal robusto para a criação, emplementação e gestão de unidades de conservação, no entanto, como bem lembrado por Peccatiello (2011) "a efetivação das ações e metas revela-se ainda bastante problemática, 
muito aquém do exigido pela dinâmica territorial e populacional vivenciada no país" na atualidade.

\section{Conclusão}

Ao término deste estudo, pode-se chegar às seguintes conclusões:

- Foram criadas unidades de conservação em todas as unidades federativas abrangidas pela Região Semiárida do Brasil.

- A Região Semiárida do Brasil possui 6,71\% de seu território coberto por unidades de conservação.

- O Estado do Ceará é onde mais foram criadas unidades de conservação, em termos absolutos, com 86 unidades.

- Em termos relativos, o Estado do Piauí é o que mais cobriu seu território localizado na Região Semiárida com unidades de conservação perfazendo 12,37\% de cobertura.

- $\quad$ E Estado de Minas Gerais é o que menos tem cobertura de sua Região Semiárida com unidade de conservação.

- Nos últimos 12 anos a criação de Reserva Particular do Patrimônio Natural (RPPN) aumentou consideravelmente, de 14 para 119.

- Embora a Reserva Particular do Patrimônio Natural (RPPN) seja mais numerosa, ela protege apenas $0,06 \%$ da área do semiárido.

\section{Conflito de interesses}

Os autores declaram não haver conflito de interesses.

\section{Referências}

Ab'Saber, N. A. O domínio morfoclimático semi-árido das caatingas brasileiras. Geomorfologia, n. 43, p. 1-39, 1974.

Alvares, C. A.; Stape, J. L.; Sentelhas, P. C.; Gonçalves, J. L. M.; Sparovek, G. Köppen's climate classification map for Brazil. Meteorologische Zeitschrift, v. 22, n. 6, p. 711-728, 2014. https://doi.org/10.1127/0941-2948/2013/0507

Alves, R. R. N.; Gonçalves, M. B. R.; Vieira, W. L. S. Caça, uso e conservação de vertebrados no semiárido brasileiro. Tropical Conservation Science, v. 5, n. 3, p. 394-416, 2012. https://doi.org/10.1177/194008291200500312

Andrade-Lima, D. The Caatingas dominium. Revista Brasileira de Botanica, v. 4, n. 2, p. 149-163, 1981.

Bernardes, N. As caatingas. Estudos Avançados, v. 13, n. 36, p. 69-78, 1999. https://doi.org/10.1590/S0103-40141999000200004

Braga, A. S.; Maciel, M. A. O sistema nacional de unidades de conservação e o desafio de sua implamentação. In: Thedoro, S. H. Os 30 anos da Política Nacional do Meio Ambiente: conquistas e perspectivas. Rio de Janeiro: Garamond, 2011. p. 139-165. 
Brasil. Cadastro Nacional de Unidades de Conservação. 2019. Disponível em: <https://www.mma.gov.br/areas-protegidas/cadastro-nacional-de-ucs>. Acesso em: 11 fev. 2020.

Brasil. Constituição da República Federativa do Brasil de 1988. Disponível em: <http://www.planalto.gov.br/ccivil_03/constituicao/constituicao.htm>. Acesso em: 16 jan. 2020.

Brasil. Decreto no 8.843, de 26 de julho de 1911. Crêa a reserva florestal no Territorio do Acre. Disponível em: <http://www.planalto.gov.br/ccivil_03/decreto/19101929/D08843.html>. Acesso em: 23 out. 2019.

Brasil. Decreto no 23.793, de 23 de janeiro de 1934. Approva o codigo florestal que com este baixa. Disponível em: <http://www.planalto.gov.br/ccivil_03/decreto/19301949/D23793.htm>. Acesso em: 23 out. 2019.

Brasil. Decreto no 47.570, de 31 de dezembro de 1959. Cria o Parque Nacional de Araguaia, integrante da Seção de Parques e Florestas Nacionais de Serviço Florestal do Ministério da Agricultura. Disponível em: <http://www.planalto.gov.br/ ccivil_03/decreto/1950-1969/D47570.htm>. Acesso em: 23 out. 2019.

Brasil. Decreto no 50.665, de 30 de maio de 1961. Cria o Parque Nacional de Sete Quedas e dá outras providências. Disponível em: <https://www2.camara.leg.br/legin/fed/ decret/1960-1969/decreto-50665-30-maio-1961-390248-publicacaooriginal-1-pe.html>. Acesso em: 23 out. 2019.

Brasil. Lei no 4.771, de 15 de setembro de 1965. Institui o novo Código Florestal. Disponível em: <http://legis.senado.leg.br/norma/546624>. Acesso em: 23 out. 2019.

Brasil. Lei no 5.197, de 3 de janeiro de 1967. Dispõe sôbre a proteção à fauna e dá outras providências. Disponível em: <https://legis.senado.leg.br/norma/547059/ publicacao/15775249>. Acesso em: 23 out. 2019.

Brasil. Decreto no 73.030, de 30 de outubro de 1973. Cria, no âmbito do Ministério do Interior, a Secretaria Especial do Meio Ambiente - SEMA, e da outras providências. Disponível em: <http://legis.senado.leg.br/norma/495670/publicacao/15670954>. Acesso em: 11 ago. 2019.

Brasil. Lei no 6.902, de 27 de abril de 1981. Dispõe sobre a criação de Estações Ecológicas, Áreas de Proteção Ambiental e dá outras providências. Disponível em: <http://www.planalto.gov.br/ccivil_03/LEIS/L6902.htm>. Acesso em: 23 out. 2019.

Brasil. Decreto no 86.071, de 04 de junho de 1981. Extingue o Parque Nacional de Sete Quedas, criado pelo Decreto no 50.665 , de 30 de maio de 1961, e dá outras providências. Disponível em: <http://legis.senado.leg.br/norma/508711/publicacao/15833033>. Acesso em: 23 out. 2019.

Brasil. Lei no 6.938, de 31 de agosto de 1981. Dispõe sobre a Política Nacional do Meio Ambiente, seus fins e mecanismos de formulação e aplicação, e dá outras providências. Disponível em: <http://www.planalto.gov.br/ccivil_03/LEIS/L6938.htm>. Acesso em: 11 out. 2019.

Brasil. Decreto no 89.336, de 31 de janeiro de 1984. Dispõe sobre as Reservas Econômicas e Áreas de Relevante Interesse Ecológico, e dá outras providencias. Disponível em: <http://www.planalto.gov.br/ccivil_03/decreto/1980-1989/D89336.htm>. Acesso em: 23 out. 2019. 
Brasil. Resolução CONAMA no 005, de 5 de junho de 1984. Determinar que a sua Secretaria Executiva prepare as respectivas minutas de decreto e as encaminhe ao Poder Executivo, através do Ministério do Interior, visando à implantação das seguintes Áreas de Relevante Interesse Ecológico. Disponível em: <http://www2.mma.gov.br/port/conama/ legiabre.cfm?codlegi=5>. Acesso em: 13 nov. 2019.

Brasil. Resolução CONAMA no 17, de 18 de dezembro de 1984. Dispõe sobre a execução de procedimentos administrativos visando à implantação das Áreas de Relevante Interesse Ecológico - Vale dos Dinossauros e Manguezais da Foz de Rio Mamanguape/PB. Disponível em: <http://www2.mma.gov.br/port/conama/legiabre.cfm?codlegi=17>. Acesso em: 23 out. 2019.

Brasil. Decreto no 91.145, de 15 de março de 1985. Cria o Ministério do Desenvolvimento Urbano e Meio Ambiente, dispõe sobre sua estrutura, transferindo-lhe os órgãos que menciona, e dá outras providências. Disponível em: <http://legis.senado.leg.br/norma/513785/publicacao/15673245>. Acesso em: 23 out. 2019.

Brasil. Resolução CONAMA no 11, de 3 de dezembro de 1987. Dispõe sobre a declaração, como unidades de conservação, de várias categorias de sítios ecológicos de relevância cultural. Disponível em: <http://www2.mma.gov.br/port/conama/ legiabre.cfm?codlegi=62>. Acesso em: 23 out. 2019.

Brasil. Lei no 7.804, de 18 de julho de 1989. Altera a Lei no 6.938, de 31 de agosto de 1981, que dispõe sobre a Política Nacional do Meio Ambiente, seus fins e mecanismos de formulação e aplicação, a Lei no 7.735, de 22 de fevereiro de 1989, a Lei no 6.803, de 2 de julho de 1980, e dá outras providências. Disponível em: <http://www.planalto.gov.br/ccivil_03/LEIS/L7804.htm>. Acesso em: 23 out. 2019.

Brasil. Decreto Legislativo no 2, de 1994. Aprova o texto da Convenção sobre Diversidade Biológica, assinada durante a Conferência das Nações Unidas sobre Meio Ambiente e Desenvolvimento, realizada na Cidade do Rio de Janeiro, no período de 5 a 14 de junho de 1992. Disponível em: <https://www2.camara.leg.br/legin/fed/ decleg/1994/decretolegislativo-2-3-fevereiro-1994-358280-publicacaooriginal-1pl.html>. Acesso em: 23 out. 2020.

Brasil. Decreto no 2.519, de 16 de março de 1998. Promulga a Convenção sobre Diversidade Biológica, assinada no Rio de Janeiro, em 05 de junho de 1992. Disponível em: <http://www.planalto.gov.br/ccivil_03/decreto/D2519.htm>. Acesso em: 23 out. 2019.

Brasil. Lei no 9.605, de 12 de fevereiro de 1998. Dispõe sobre as sanções penais e administrativas derivadas de condutas e atividades lesivas ao meio ambiente, e dá outras providências. Disponível em: <http://www.planalto.gov.br/ccivil_03/leis/19605.htm>. Acesso em: 23 out. 2019.

Brasil. Decreto no 3.179, de 21 de setembro de 1999. Dispõe sobre a especificação das sanções aplicáveis às condutas e atividades lesivas ao meio ambiente, e dá outras providências. Disponível em: <http://www.planalto.gov.br/ccivil_03/decreto/ D3179.htm>. Acesso em: 23 out. 2019.

Brasil. Lei no 9.985, de 18 de julho de 2000. Regulamenta o art. 225, § 1ํㅡ, incisos I, II, III e VII da Constituição Federal, institui o Sistema Nacional de Unidades de Conservação da Natureza e dá outras providências. Disponível em: <http://www.planalto.gov.br/ ccivil_03/leis/19985.htm>. Acesso em: 23 out. 2019. 
Brasil. Decreto no 4.340, de 22 de agosto de 2002. Regulamenta artigos da Lei no 9.985, de 18 de julho de 2000, que dispõe sobre o Sistema Nacional de Unidades de Conservação da Natureza-SNUC, e dá outras providências. Disponível em: <http://www.planalto.gov.br/ccivil_03/decreto/2002/D4340.htm>. Acesso em: 23 out. 2019.

Brasil. Decreto no 5.092, de 21 de maio de 2004. Define regras para identificação de áreas prioritárias para a conservação, utilização sustentável e repartição dos benefícios da biodiversidade, no âmbito das atribuições do Ministério do Meio Ambiente. Disponível em: <https://www.planalto.gov.br/ccivil_03/_Ato2004-2006/2004/Decreto/D5092.htm>.

Acesso em: 23 out. 2019.

Brasil. Medida Provisória no 366, de 26 de abril de 2007. Dispõe sobre a criação do Instituto Chico Mendes de Conservação da Biodiversidade - Instituto Chico Mendes, e dá outras providências. Disponível em: <http://www.planalto.gov.br/ccivil_03/_Ato20072010/2007/Mpv/366.htm>. Acesso em: 23 out. 2019.

Brasil. Lei no 11.516, de 28 de agosto de 2007. Dispõe sobre a criação do Instituto Chico Mendes de Conservação da Biodiversidade - Instituto Chico Mendes; altera as Leis nos 7.735, de 22 de fevereiro de 1989, 11.284, de 2 de março de 2006, 9.985, de 18 de julho de 2000, 10.410, de 11 de janeiro de 2002, 11.156, de 29 de julho de 2005, 11.357, de 19 de outubro de 2006, e 7.957, de 20 de dezembro de 1989; revoga dispositivos da Lei no 8.028 , de 12 de abril de 1990, e da Medida Provisória no 2.216-37, de 31 de agosto de 2001; e dá outras providências. Disponível em: <http://www.planalto.gov.br/ccivil_03/_Ato20072010/2007/Lei/L11516.htm>. Acesso em: 23 out. 2019.

Brasil. Decreto no 6.514, de 22 de julho de 2008. Dispõe sobre as infrações e sanções administrativas ao meio ambiente, estabelece o processo administrativo federal para apuração destas infrações, e dá outras providências. Disponível em: <http://www.planalto.gov.br/ccivil_03/_Ato2007-2010/2008/Decreto/D6514.htm>. Acesso em: 23 out. 2019.

Brasil. Decreto no 6.686, de 10 de dezembro de 2008. Altera e acresce dispositivos ao Decreto $\mathrm{n}^{\circ}$ 6.514, de 22 de julho de 2008, que dispõe sobre as infrações e sanções administrativas ao meio ambiente e estabelece o processo administrativo federal para apuração destas infrações. Disponível em: <http://www.planalto.gov.br/ccivil_03/ _Ato2007-2010/2008/Decreto/D6686.htm>. Acesso em: 23 out. 2019.

Brasil. Resolução CONAMA no 428, de 17 de dezembro de 2010. Dispõe, no âmbito do licenciamento ambiental sobre a autorização do órgão responsável pela administração da Unidade de Conservação (UC), de que trata o § $3^{\circ}$ do artigo 36 da Lei no 9.985 de 18 de julho de 2000, bem como sobre a ciência do órgão responsável pela administração da UC no caso de licenciamento ambiental de empreendimentos não sujeitos a EIA-RIMA e dá outras providências. Disponível em: <http://www2.mma.gov.br/port/conama/ legiabre.cfm?codlegi=641>. Acesso em: 17 jan. 2020.

Brasil. Resolução no 473, de 11 de dezembro de 2015. Prorroga os prazos previstos no $\S 2^{\circ}$ do art. $1^{\circ}$ e inciso III do art. 5o da Resolução no 428, de 17 de dezembro de 2010, que dispõe no âmbito do licenciamento ambiental sobre a autorização do órgão responsável pela administração da Unidade de Conservação (UC), de que trata o § $3^{\circ}$ do artigo 36 da Lei no 9.985 de 18 de julho de 2000, bem como sobre a ciência do órgão responsável pela administração da UC no caso de licenciamento ambiental de empreendimentos não sujeitos a EIA-RIMA e dá outras providências. Disponível em: 
<http://www2.mma.gov.br/port/conama/legiabre.cfm?codlegi=719>. Acesso em: 23 out. 2019.

Brasil. Resolução no 107/2017. Estabelece critérios técnicos e científicos para delimitação do Semiárido Brasileiro e procedimentos para revisão de sua abrangência. Disponível em: <http://sudene.gov.br/images/2017/arquivos/Resolucao-107-2017.pdf>. Acesso em: 23 out. 2019.

Brasil. Resolução SUDENE/CONDEL no 115, de 23 de novembro de 2017. Disponível em: <http://www.in.gov.br/web/dou/-/resolucao-n-115-de-23-de-novembro-de-2017739564>. Acesso em: 23 out. 2019.

Brasileiro, D. P.; Madruga Filho, V. J. P.; Paz, R. J.; Lucena, R. F. P. Plantas e animais medicinais: análise da legislação brasileira. In: Lucena, R. F. P.; Lucena, C. M.; Carvalho, T. K. N.; Ferreira, E. C. (Orgs.). Plantas e animais medicinais da Paraíba: visões da Etnobiologia e Etnoecologia. Cabedelo: Editora do IESP, 2018. p. 254-271. Disponível em: $<$ https://www.iesp.edu.br/sistema/uploads/arquivos/publicacoes/plantas-e-animaismedicinais-da-paraiba-visoes-da-etnobiologia-e-etnoecologia.pdf\#page=256>. Acesso em: 21 jan. 2020.

Brundtland, G. H. Report of the World Commission on Environment and Development: Our common future. Washington: UN, 1987. Disponível em: $<$ https://sustainabledevelopment.un.org/content/documents/5987our-commonfuture.pdf>. Acesso em: 20 jan. 2020.

Carson, R. Primavera silenciosa. São Paulo: Gaia, 2010.

Corrêa, R. S.; Abreu, G. R. A. O dano a unidades de conservação nos termos do artigo 40 da Lei de Crimes Ambientais. Revista Brasileira de Criminalista, v. 3, n. 2, p. 11-16, 2014. https://doi.org/10.15260/rbc.v3i2.75

Coutinho, P. C.; Soares, Z. A.; Ferreira, E. C.; Souza, D. V.; Oliveira, R. S.; Lucena, R. F. P. Knowledge and use of medicinal plants in the Semiarid Region of Brazil. Brazilian Journal of Biological Sciences, v. 2, n. 3, p. 51-74, 2015.

Falcão, F. C.; Tavares, V. C. Bats of RPPN Pé de Serra, a reserve of Caatinga in the Northeastern Brazil. Revista Nordestina de Biologia, v. 28 n. 1, 2020. https://doi.org/10.22478/ufpb.2236-1480.2019v27n1.46053

Farena, D. V. M. Aspectos polêmicos acerca da criação e implantação de unidades de conservação. Boletim Científico ESMPU, v. 6, n. 24/25, p. 123-150, 2007.

Farias, T. Reserva Particular do Patrimônio Natural: uma análise de seu regime jurídico. In: Paz, R. J.; Luna, R. G.; Farias, T. (Orgs.). Gestão ambiental: o caminho para a sustentabilidade. João Pessoa: Editora Universitária/UFPB, 2010. p. 167-180.

Ferreira, M. B. M.; Salles, A. O. T. Política ambiental brasileira: análise histórico-constitucionalista das principais abordagens estratégicas. Revista de Economia, v. 42, n. 2, 2016. https://doi.org/10.5380/re.v42i2.54001

Franca-Rocha, W.; Silva, A. B.; Chaves, J. M.; Nolasco, M. C.; Accioly, L. J. O.; Sá, I. B.; Pareyn, F. G. C. Levantamento da cobertura vegetal e do uso do solo no Bioma das Caatingas. In: Queiroz, L. P.; Rapini, A.; Giulietti, A. M. (Eds.). Rumo ao amplo conhecimento da biodiversidade do semi-árido brasileiro. Brasília: Ministério da Ciência e Tecnologia, 2006. 
Guimarães, J. C. C.; Machado, F. S.; Borges, L. A. C.; Rezende, J. L. P.; Soares, A. A. V.; Santos, A. A. Aspectos legais do entorno das unidades de conservação brasileiras: área circundante e zona de amortecimento em face à Resolução CONAMA no 428/2010. Espaço \& Geografia, v. 15, n. 1, p. 1-20, 2012.

IBDF - Instituto Brasileiro de Desenvolvimento Florestal. Plano de Manejo do Parque Nacional de Sete Cidades. Brasília: IBDF, 1979. Disponível em: <http://www.icmbio.gov.br/portal/images/stories/imgs-unidades-coservacao/PARNA SETE CIDADES.pdf>. Acesso em: 20 jan. 2020.

IBGE - Instituto Brasileiro de Geografia e Estatística. Brasil: Cidades e Estados. 2019. Disponível em: <https://www.ibge.gov.br/cidades-e-estados.html>. Acesso em: 23 out. 2019.

Jenkins, C. N.; Joppa, L. Expansion of the global terrestrial protected area system. Biological Conservation, v. 142, p. 2166-2174, 2009. https://doi.org/10.1016/ j.biocon.2009.04.016

Jorge Pádua, M. T. Sistema Brasileiro de Unidades de Conservação: de onde viemos e para onde vamos? Anais do I Congresso Brasileiro de Unidades de Conservação, Curitiba, p. 214-136, 1997.

Lacerda, A. C.; Albuquerque, J. V.; Galvíncio, J. D. Área legalmente protegida sob conflito: o caso da Reserva de Vida Silvestre Tatu-Bola, Estado de Pernambuco, Brasil. Revista Brasileira de Gestão Ambiental e Sustentabilidade, v. 4, n. 7, p. 91-202, 2017. https://doi.org/10.21438/rbgas.040719

Lacerda, A. V.; Barbosa, F. M. Análise florística de uma vegetação ciliar em área de caatinga no semi-árido paraibano. In: Paz, R. J.; Farias, T. Gestão de áreas protegidas: processos e casos particulares. João Pessoa: Editora Universitária/UFPB, 2008. p. 251-269.

Leal, I. R.; Silva, J. M. C.; Tabarelli, M.; Lacher Jr., T. E. Mudando o curso da conservação da biodiversidade na Caatinga do Nordeste do Brasil. Megadiversidade, v. 1, n. 1, p. 139-146, 2005.

Lino, C. F.; Borges, C. R.; Dal'ava, F.; Néo, F. A.; Barbosa, F. A. R.; Sales, G.; Dutra, G. F.; Herrmann, G.; Câmara, I. G.; Jorge Pádua, M. T.; Pereira, P. G. P.; Nogueira Neto, P.; Cavalcanti, R. B.; Coutinho, S. C.; Magnusson, W.; Loureiro, W. Estratégia nacional de diversidade biológica: contribuição para a estratégia de conservação in-situ no Brasil. 1999. Disponível em: <https://www.mma.gov.br/estruturas/sbf_chm_rbbio/ _arquivos/Conservacao in situ.pdf>. Acesso em: 20 jan. 2020.

Loucks, C.; Rickets, T. H.; Naidoo, R.; Lamoreux, J.; Hoekstra, J. Explaining the global pattern of protected area coverage: Relative importance of vertebrate biodiversity, human activities and agricultural suitability. Journal of Biogeography, v. 35, n. 8, p. 1337-1348, 2008. https://doi.org/10.1111/j.1365-2699.2008.01899.x

Lucena, R. F. P.; Silva, J. R. S.; Ferreira, E. C.; Barbosa, D. A.; Carvalho, T. K. N.; Santos, S. S.; Meira, K. R. F.; Marreiros, N. A.; Coutinho, P. C.; Bonifácio, K. M. Conhecimento e uso de plantas medicinais no Semiárido da Paraíba, Nordeste do Brasil. In: Lucena, R. F. P.; Lucena, C. M.; Carvalho, T. K. N.; Ferreira, E. C. (Orgs.). Plantas e animais medicinais da Paraíba: visões da Etnobiologia e Etnoecologia. Cabedelo: Editora do IESP, 2018. p. 51-74. Disponível em: <https://www.iesp.edu.br/sistema/uploads/arquivos/publicacoes/ plantas-e-animais-medicinais-da-paraiba-visoes-da-etnobiologia-eetnoecologia.pdf\#page=53>. Acesso em: 21 jan. 2020. 
Maciel, B. A. Unidades de conservação no bioma Caatinga. In: Gariglio, M. A.; Sampaio, E. V. S. B.; Cestaro, L. A.; Kageyama, P. Y. Uso sustentável e conservação dos recursos florestais da Caatinga. Brasília: Serviço Florestal Brasileiro, 2010. p. 76-81.

Meadows, D. H.; Meadows, D. L.; Randers, J.; Behrens III, W. W. The limits of growth: A report for the Club of Rome's project on the predicament of mankind. New York: Universe Books, 1972. Disponível em: <http://www.donellameadows.org/wpcontent/userfiles/Limits-to-Growth-digital-scan-version.pdf>. Acesso em: 20 jan. 2020.

Melo, F. P.; Siqueira, J. A.; Santos, B. A.; Silva, O. A.; Ceballos, G.; Bernard, E. Football and biodiversity conservation: FIFA and Brazil canstill hit a green goal. Biotropica, v. 46, n. 3, p. 257-259, 2014. https://doi.org/10.1111/btp.12114

Mendonça, L. E. T.; Souto, C. M.; Andrelino, L. L.; Souto, W. M. S.; Vieira, W. L. S.; Alves, R. R. N. Conflitos entre pessoas e animais silvestres no Semiárido paraibano e suas implicações para conservação. Sitientibus, Série Ciências Biológicas, v. 11, n. 2, p. 185-199, 2011.

Mittermeier, R. A.; Fonseca, G. A. B.; Rylands, A. B.; Brandon, K. Uma breve história da conservação da biodiversidade no Brasil. Megadiversidade, v. 1, n. 1, p. 14-21, 2005.

Naess, A. The shallow and the deep, long-rangeecology movement. A summary. Inquiry: An Interdisciplinary Journal of Philosophy, v. 16, n. 1/4, p. 95-100, 1973. https://doi.org/10.1080/00201747308601682

Nascimento, E. P. The trajectory of sustainability: From environmental to social, from social to economic. Estudos Avançados, v. 26, n. 74, p. 51-64, 2012. https://doi.org/10.1590/S0103-40142012000100005

Oliveira, F. C. S.; Marques, J.; Bomfim, L. Ecologia das águas e das almas de Boquira: dilemas socioambientais no sertão baiano. Revista Ecologias Humanas, v. 3, n. 3, p. 31-52, 2017.

Oliveira, J. C.; Barbosa, J. H. C. Roteiro para a criação de unidades de conservação municipais. Brasília: Ministério do Meio Ambiente, 2010.

Peccatiello, A. F. O. Políticas públicas ambientais no Brasil: da administração dos recursos naturais (1930) à criação do Sistema Nacional de Unidades de Conservação (2000). Desenvolvimento e Meio Ambiente, n. 24, p.71-82, 2011. https://doi.org/10.5380/dma.v24i0.21542

Paz R. J.; Freitas, G. L.; Souza, E. A. As áreas protegidas na legislação brasileira. In: Paz, R. J.; Farias, T. (Orgs.). Gestão de áreas protegidas: processos e casos particulares. João Pessoa: Editora Universitária/UFPB, 2008. p. 21-40.

Paz R. J.; Freitas, G. L.; Souza, E. A. Unidades de conservação no Brasil: história e legislação. João Pessoa: Editora Universitária/UFPB, 2006.

Rodrigues, A. S. L.; Akçakaya, H. R.; Andelman, S. J.; Bakarr, M. I.; Boitani, L.; Brooks, T. M.; Chanson, J. S.; Fishpool, L. D. C.; Fonseca, G. A. B.; Gaston, K. J.; Hoffmann, M.; Marquet, P. A.; Pilgrim, J. D.; Pressey, R. L.; Schipper, J.; Sechrest, W.; Stuart, S. N.; Underhill, L. G.; Waller, R. W.; Watts, M. E. J.; Yan, X. Global gap analysis: Priority regions for expanding the global protected-area network. BioScience, v. 54, n. 12, p.1092-1097, 2004a. https://doi.org/10.1641/0006-3568(2004)054[1092:GGAPRF]2.0.CO;2

Rodrigues, A. S. L.; Andelman, S. J.; Bakarr, M. I.; Boitani, L.; Brooks, T. M.; Cowling, R. M.; Fishpool, L. D. C.; Fonseca, G. A. B.; Gaston, K. J.; Hoffmann, M.; Long, J. S.; Marquet, P. A.; Pilgrim, J. D.; Pressey, R. L.; Schipper, J.; Sechrest, W.; Stuart, S. N.; Underhill, L. G.; Waller, 
R. W.; Watts, M. E. J.; Yan, X. Effectiveness of the global protected area network in representing species diversity. Nature, v. 428, p. 640-643, 2004b. https://doi.org/ $10.1038 /$ nature 02422

Santana, M. O. (Org.). Atlas das áreas susceptíveis à desertificação do Brasil. Brasília: MMA, 2007.

Silva, A. C. C.; Prata, A. P. N.; Mello, A. A. Florísitica, fitossociologia e caracterização sucessional em um remanescente de Caatinga em Sergipe. Gaia Scientia, v. 10, n. 4, p. 114, 2016.

Silva, J. I. A. O. Conservação da Natureza em áreas privadas: uma análise do modelo RPPN no semi-árido paraibano. In: Paz, R. J.; Farias, T. (Orgs.). Gestão de áreas protegidas: processos e casos particulares. João Pessoa: Editora Universitária/UFPB, 2008. p. 199-234.

Silva, J. I. A. O.; Cunha, L. H. Regime jurídico das unidades de conservação: suas características jurídico-ambientais. Revista Dataveni@, v. 2, n. 1, p. 121-143, 2010. https://dois.org/10.20887/rdtv.ccj.2010.17.507

Vital, A. V. As "florestas sagradas" do impasse: a Reserva Florestal do Território Federal do Acre (1911). HALAC - Historia Ambiental, Latinoamericana y Caribeña, v. 8, n. 1, p. 4266, 2018. https://doi.org/10.32991/2237-2717.2018v8i1.p42-66

Informação da Licença: Este é um artigo Open Access distribuído sob os termos da Licença Creative Commons Attribution, que permite uso irrestrito, distribuição e reprodução em qualquer meio, desde que a obra original seja devidamente citada. 